\title{
WestVirginiaUniversity
}

THE RESEARCH REPOSITORY @ WVU

Graduate Theses, Dissertations, and Problem Reports

2017

\section{Monetary Policy, Economic Conditions, and Income Inequality}

\author{
Edmond Berisha
}

Follow this and additional works at: https://researchrepository.wvu.edu/etd

\section{Recommended Citation}

Berisha, Edmond, "Monetary Policy, Economic Conditions, and Income Inequality" (2017). Graduate Theses, Dissertations, and Problem Reports. 5189.

https://researchrepository.wvu.edu/etd/5189

This Dissertation is protected by copyright and/or related rights. It has been brought to you by the The Research Repository @ WVU with permission from the rights-holder(s). You are free to use this Dissertation in any way that is permitted by the copyright and related rights legislation that applies to your use. For other uses you must obtain permission from the rights-holder(s) directly, unless additional rights are indicated by a Creative Commons license in the record and/ or on the work itself. This Dissertation has been accepted for inclusion in WVU Graduate Theses, Dissertations, and Problem Reports collection by an authorized administrator of The Research Repository @ WVU.

For more information, please contact researchrepository@mail.wvu.edu. 


\title{
Monetary Policy, Economic Conditions, and Income Inequality
}

\section{Edmond Berisha}

\author{
Dissertation submitted \\ to the College of Business and Economics \\ at West Virginia University \\ in partial fulfillment of the requirements for the degree of \\ Doctor of Philosophy in \\ Economics
}

\begin{abstract}
Eric Olson, Ph.D., chair
Arabinda Basistha, Ph.D.

Shuichiro Nishioka, Ph.D.

Brian Cushing, Ph.D.

Jack Dorminey, Ph.D.
\end{abstract}

Department of Economics

Morgantown, West Virginia

2017

\begin{abstract}
Keywords: monetary policy, VAR, income inequality, household debt, yield spread, ECB, inflation, Non-Euro Member.
\end{abstract}

Copyright @ 2017 Edmond Berisha 


\section{Abstract \\ Monetary Policy, Economic Conditions, and Income Inequality}

\section{Edmond Berisha}

This dissertation is a collection of three chapters. The first chapter empirically investigates the relationship between interest rates, the stock market, household debt, and the distribution of income in the U.S. The results indicate that increases in the stock market and household debt increase income inequality. Moreover, the relationship between the interest rate and income inequality is found to be negative and statistically significant.

The second chapter examines the relationship between the yield spread and the income distribution. The yield spread is known to be closely related with business cycles identified by the National Bureau of Economic Research. It is low near peaks and high near troughs. This chapter builds on this known relationship and examines the response of the income distribution in the U.S. due to variation in the yield spread. The purpose is to identify the significance and sign of the impact changes in economic conditions have on the distribution of income over the period 19272011. Clark and McCracken's (2001) 1-step ahead encompassing tests from nested linear models are initially estimated to determine the predictive power of the yield spread on the distribution of income. Results strongly reject the null hypothesis that the yield spread has no predictive content for changes in the distribution of income. Specifically, increases in the yield spread are found to correspond with subsequent increases in top income shares. 
The third chapter analyses the importance of ECB monetary policy shocks in the domestic activities of a non-EMU member, Croatia, with the main focus on the inflation rate. Using a Vector Autoregressive Model with an exogenous variable specification, it is found that the contraction of foreign monetary shocks have a significant positive impact on the local inflation rate and output. Interestingly, the interest rate gap exerts a statistically significant effect on the economic activities of Croatia, suggesting that targeting exchange rate stability does not eliminate the significance of ECB's monetary policy changes. 


\section{Acknowledgements}

I would not be able to complete my dissertation without the support of my professors, colleagues, and my family. I would like to thank my dissertation committee: Eric Olson, Arabinda Basistha, Shuichiro Nishioka, Brian Cushing, and Jack Dorminey. Particularly, I am thankful to my advisor, Eric Olson, for the time he has spent to guide me on how to clearly communicate my research ideas. Also, conversations with Arabinda Basistha and Shuichiro Nishioka have been very helpful in advancing my research agenda. Working together with my colleague and a great friend,

John Meszaros, has been very helpful in being efficient in completing this thesis. Lastly, I would like thank my parents, Fevzi Berisha and Elvane Berisha, and my wife, Rreze Zejnullahi, for their endless support. 


\section{Table of Contents}

1. INCOME INEQUALITY, EQUITIES, HOUSEHOLD DEBT, AND INTEREST

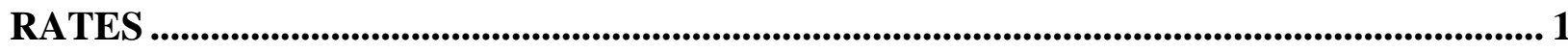

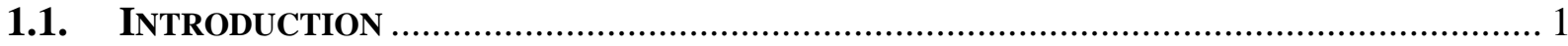

1.2. INEQUALITY AND THE COMPOSITION OF HOUSEHOLD WEALTH …………................. 4

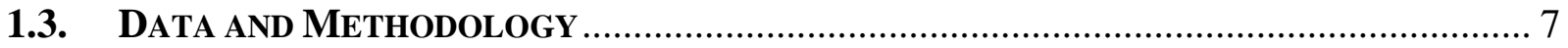

1.3.1. Data

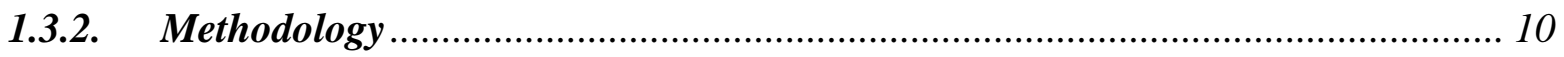

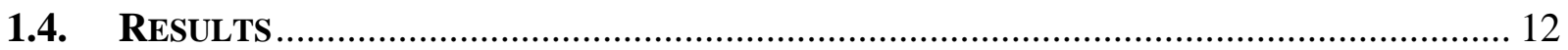

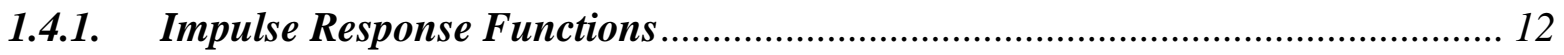

1.4.2. Generalized Variance Decompositions ………….......................................... 15

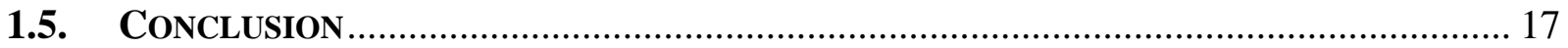

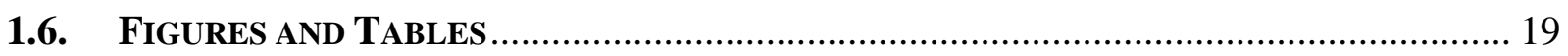

2. YIELD SPREAD AND THE INCOME DISTRIBUTION ................................................. 30

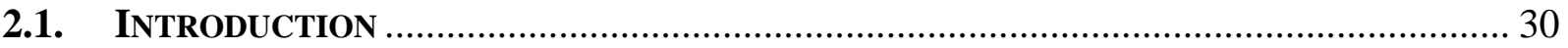

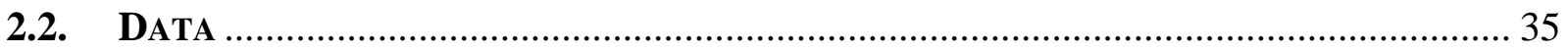

2.3. Clark AND MCCRACKen OUt OF SAMPLE TESTS AND ReSUltS ............................... 37

2.4. GENERALIZED IMPULSE REPONSES AND GENERALIZED VARIANCE DECOMPOSITIONS 38

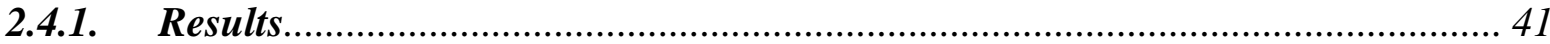

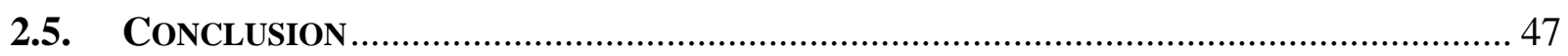

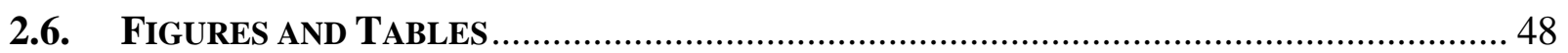

3. ECB MONETARY POLICY ACTIONS AND THE ECONOMIC CONDITIONS OF A NON-EURO MEMBER: THE CASE OF CROATIA........................................................ 73

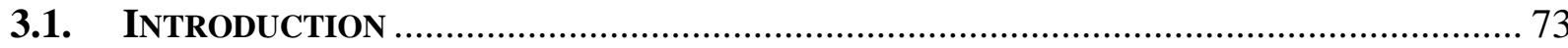

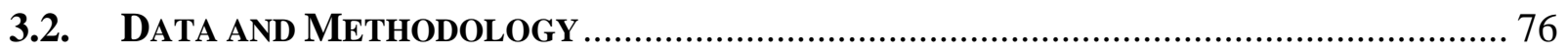

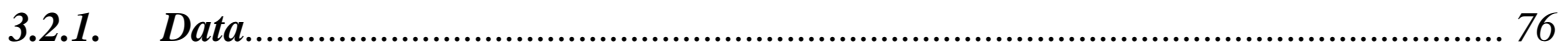

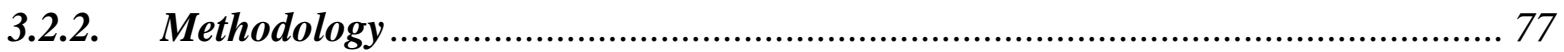

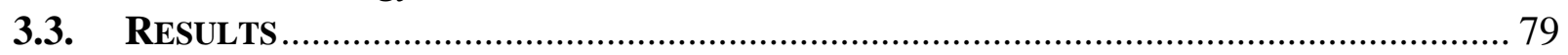

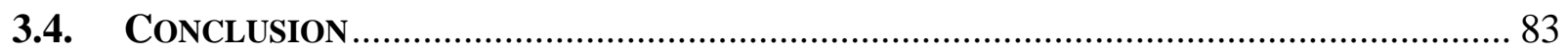

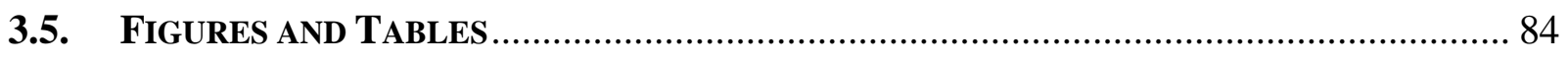

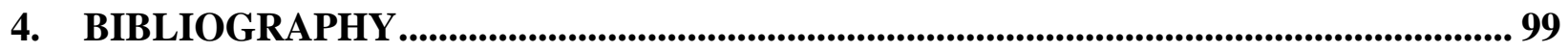




\section{List of Figures}

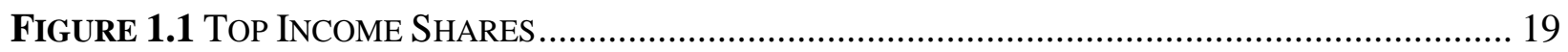

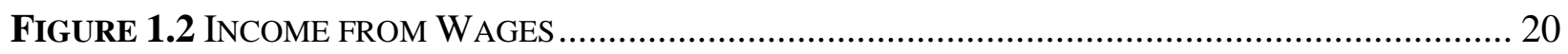

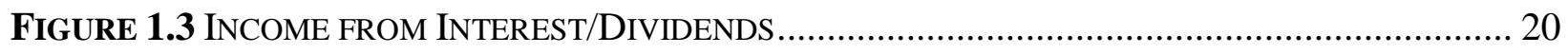

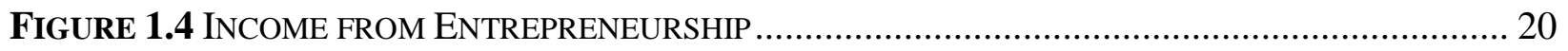

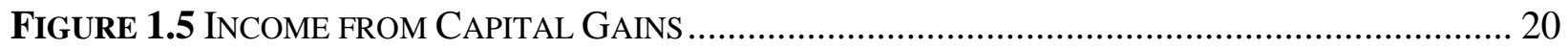

Figure 1.6 Household Wealth: Middle 3 Quintiles............................................................ 21

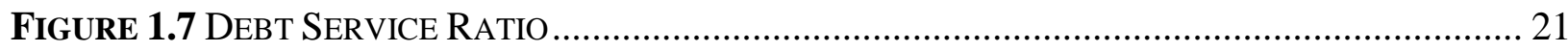

Figure 1.8 LeVerage Ratio by Household Income Percentile ............................................ 21

Figure 1.9 MEdian VALUE OF FinANCIAL ASSETS................................................................... 21

FigURE 1.10 TIME SERIES OF INCOME INEQUALITY MEASURES ...................................................... 22

Figure 1.11 Generalized IMPULSE RESPONSES USING Gini COEFFICIENT AS INCOME

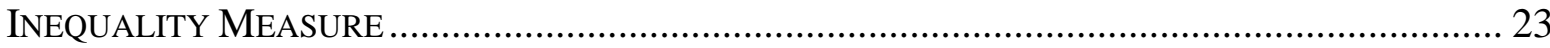

Figure 1.12 GENERALIZED IMPULSE RESPONSES USING 1\% THEIL INDEX AS INCOME INEQUALITY

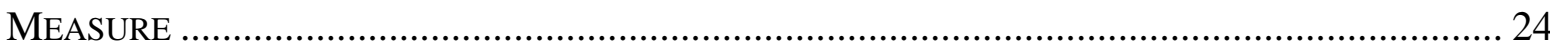

FigURE 1.13 GENERALIZED IMPULSE RESPONSES OF INCOME INEQUALITY USING INVERTED PARETO COEFFICIENT AS INCOME INEQUALITY MEASURE ................................................... 25

Figure 1.14 ChOLESKi DeCOMPOSITION: IMPULSE RESPONSES USING Gini COEFFICIENT AS

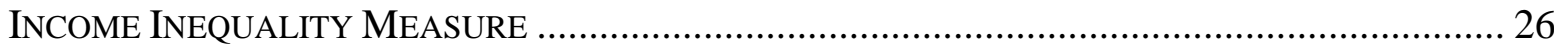

Figure 1.15 ChOLESKi DeCOMPOSITION: IMPULSE RESPONSES USING 1\% THEIL INDEX AS

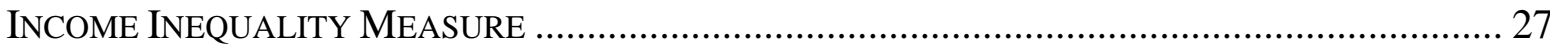

FigURE 1.16 CHOLESKI DECOMPOSITION: IMPULSE RESPONSES OF INCOME INEQUALITY USING INVERTED PARETO COEFFICIENT AS INCOME INEQUALITY MEASURE ..................................... 28

FigURE 2.1 VARIATION OF YIELD SPREAD OVERTIME .............................................................. 48

FigURE 2.2 MEDIAN VALUE OF FinanCIAL ASSETS............................................................... 49

FigURE 2.3 Time VARIATION OF THE THREE INCOME INEQUALITY MEASURES ..............................50

FiguRE 2.4 GENERALIZED IMPULSE RESPONSES OF INCOME INEQUALITY USING GINI AS INCOME

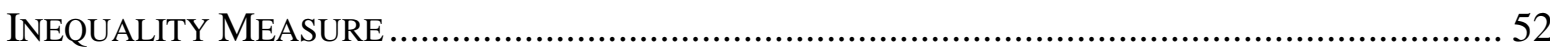

FigURE 2.5 GENERALIZED IMPULSE RESPONSES OF INCOME INEQUALITY USING TOP $1 \%$ THIEL

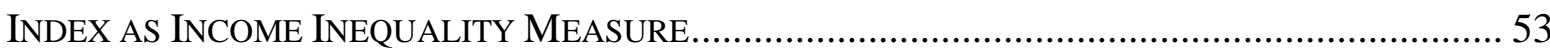

Figure 2.6 GeNERALIZED IMPULSE RESPONSES OF INCOME INEQUALITY USING IPAR AS INCOME

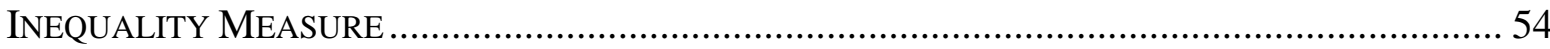

Figure 2.7 GENERALIZED IMPULSE RESPONSES OF INCOME INEQUALITY USING GiNI AS INCOME INEQUALITY MEASURE

FiguRE 2.8 GENERALIZED IMPULSE RESPONSES OF INCOME INEQUALITY USING TOP 1\% THIEL

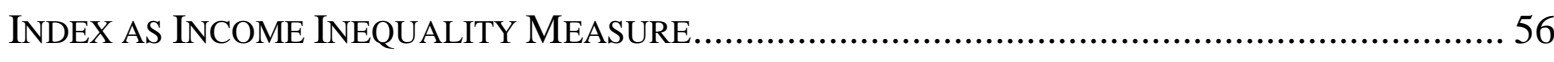

Figure 2.9 GeNERALIZED IMPULSE RESPONSES OF INCOME INEQUALITY USING IPAR AS INCOME INEQUALITY MEASURE

Figure 2.10 Generalized IMPULSE ReSPONSES OF EXPECTED RETURNS Using Gini as InCOME INEQUALITY MEASURE 
Figure 2.11 GENERALIZED IMPULSE RESPONSES OF EXPECTED RETURNS USING TOP 1\% THIEL

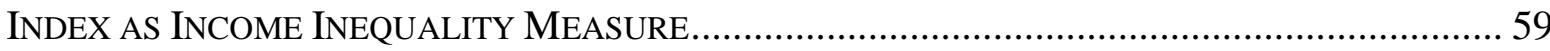

FigURE 2.12 GENERALIZED IMPULSE RESPONSES OF EXPECTED RETURNS USING IPAR AS INCOME INEQUALITY MEASURE

Figure 2.13 GENERALIZED IMPULSE RESPONSES OF REALIZED FUTURE GROWTH USING GiNI AS INCOME INEQUALITY MEASURE

Figure 2.14 GenERALIZED IMPULSE RESPONSES OF REALIZED FutURE GrOWTH Using ToP 1\% THIEL INDEX AS INCOME INEQUALITY MEASURE 62

Figure 2.15 GENERALIZED IMPULSE RESPONSES OF REALIZED FUTURE GROWTH USING IPAR AS INCOME INEQUALITY MEASURE

Figure 2.16 GENERALIZED IMPULSE RESPONSES OF UNEMPLOYMENT USING GINI COEFFICIENT AS INCOME INEQUALITY MEASURE

Figure 2.17 GENERALIZED IMPULSE RESPONSES OF UNEMPLOYMENT USING TOP 1\% THIEL INDEX AS INCOME INEQUALITY MEASURE. 65

FIGURE 2.18 GENERALIZED IMPULSE RESPONSES OF UNEMPLOYMENT USING IPAR AS INCOME INEQUALITY MEASURE 66

FIGURE 2.19 GENERALIZED IMPULSE RESPONSES OF UNEMPLOYMENT USING GINI COEFFICIENT AS INCOME INEQUALITY MEASURE

FigURE 2.20 GENERALIZED IMPULSE RESPONSES OF UNEMPLOYMENT USING TOP 1\% THIEL INDEX AS INCOME INEQUALITY MEASURE.

FIGURE 2.21 GENERALIZED IMPULSE RESPONSES OF UNEMPLOYMENT USING IPAR AS INCOME INEQUALITY MEASURE

Figure 2.22 Diebold AND YilmaZ (2012) VARIANCE DECOMPOSITIONS USING Gini COEFFICIENT AS INCOME INEQUALITY MEASURE.

FiguRE 2.23 DiebOLD AND YiLMAZ (2012) VARIANCE DECOMPOSITIONS USING TOP 1\% THIEL INDEX AS INCOME INEQUALITY MEASURE.

Figure 2.24 Diebold AND YiLMAZ (2012) VARIANCE DECOMPOSITIONS USING INVERTED PARETO LORENZ COEFFICIENT (IPAR) AS INCOME INEQUALITY MEASURE ......................... 72

Figure 3.1 GROWTH RATES OF KEY VARIABLES ….................................................. 84

Figure 3.2 CORRELATION BETWEEN ECB POLICY RATE (EURIBOR) AND CROATIAN INFLATION RATE 85

Figure 3.3 CoRRELATION BETWEEN ECB MRO RATE AND CROATIAN INFLATION RATE............ 85

Figure 3.4 IMPULSE RESPONSES OF CROATIAN DOMESTIC VARIABLES TO 1 UNIT POSITIVE SHOCK TO EURIBOR 86

Figure 3.5 IMPUlSE RESPONSES OF CROATIAN DOMESTIC VARIABLES TO 1 UNIT POSITIVE SHOCK TO EURIBOR.

Figure 3.6 IMPUlse ResPonses of CROATIAN DOMESTIC VARIABLES TO 1 UNIT POSITIVE SHOCK TO EURIBOR.... 88

Figure 3.7 IMPUlse ReSPONSES OF CROATIAN DOMESTIC VARIABLES TO 1 UNIT POSITIVE SHOCK TO MRO 89

Figure 3.8 IMPULSE RESPONSES OF CROATIAN DOMESTIC VARIABLES TO 1 UNIT POSITIVE SHOCK TO MRO 90

Figure 3.9 IMPULSE RESPONSES OF INFLATION RATE. 91 


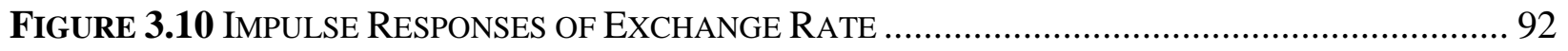

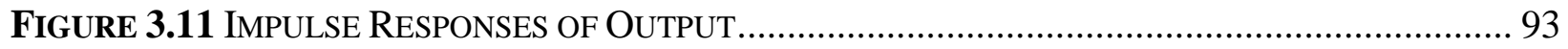

FigURE 3.12 IMPULSE RESPONSES OF THE INTEREST RATE SPREAD ....................................... 94

Figure 3.13 IMPUlse RESPONSES OF GROWTH RATE IN DOMESTIC MONEY SuPPly.................. 95

FIGURE 3.14 IMPULSE RESPONSES OF THE INTEREST RATE SPREAD ........................................ 96

FIGURE 3.15 IMPULSE RESPONSES OF INFLATION RATE ......................................................... 97

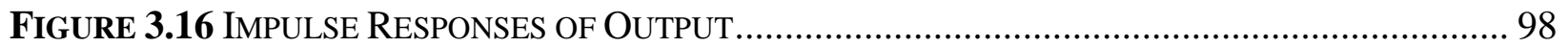




\section{List of Tables}

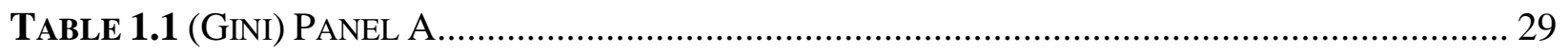

TABle 1.2 (Top 1\% ThIEL IndeX) PANEL B .......................................................................... 29

TABLE 1.3 (IPAR) PANEL C ........................................................................................... 29

TABLE 2.1 TESTS OF PREDICTIVE POWER OF THE YIELD SPREAD FOR ALL THREE MEASURES OF

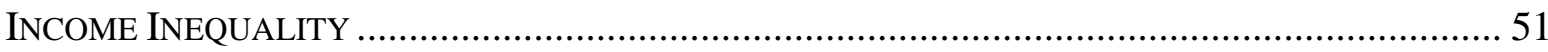




\section{Income Inequality, Equities, Household Debt, and Interest Rates}

\subsection{Introduction}

On October $17^{\text {th }}, 2014$, Federal Reserve Chairwoman Janet Yellen spent a substantial part

of her confirmation hearing discussing questions regarding income inequality in the United States

from the U.S. Senate. Subsequently, at a Boston Federal Reserve Conference on Economic

Opportunity and Inequality she stated:

“......The extent of and continuing increase in inequality in the United States greatly concern me. The past several decades have seen the most sustained rise in inequality since the 19th century after more than 40 years of narrowing inequality following the Great Depression. By some estimates, income and wealth inequality are near their highest levels in the past hundred years, much higher than the average during that time span and probably higher than for much of American history before then. It is no secret that the past few decades of widening inequality can be summed up as significant income and wealth gains for those at the very top and stagnant living standards for the majority. I think it is appropriate to ask whether this trend is compatible with values rooted in our nation's history, among them the high value Americans have traditionally placed on equality of opportunity."1

Federal Reserve officials have often discussed income inequality in speeches, however, there is not a consensus regarding the degree to which income inequality should be a concern for the

Federal Reserve. Chairman Alan Greenspan in 1998 stated,

“.......We need to ask, for example, whether we should be concerned with the degree of income inequality if all groups are experiencing relatively rapid gains in their real incomes, though those rates of gain may differ. And, we cannot ignore what is happening to the level of average income while looking at trends in the distribution. In this regard, our goal as central bankers should be clear: We must pursue monetary conditions in which stable prices contribute to maximizing sustainable long-run growth." ${ }^{2}$

Historically, the primary channel that the central bank could redistribute wealth and income

was thought to be the inflation rate; however, given the debates regarding the central bank's role in recent financial crisis and the degree to which interest rates were "kept too low for too long", this paper explores whether that there is a debt and equity channel through which interest rates

\footnotetext{
${ }^{1} \mathrm{http}: / / \mathrm{www}$. federalreserve.gov/newsevents/speech/yellen20141017a.htm

${ }^{2}$ http://www.federalreserve.gov/boarddocs/speeches/1998/19980828.htm
} 
may drive changes in income inequality through either increased household debt or by increasing the value of financial assets.

Past studies have identified the positive association between debt and income inequality. Kumhof and Ranciere (2013) provide a consistent theoretical framework linking income inequality and debt-to-income ratios. In their model, the key mechanism is that top earners use a substantial portion of their income to accumulate financial wealth through loans to those at the low end of the income distribution. ${ }^{3}$ Iacovello (2008), using a DSGE model, shows that income inequality has primarily been increased by an expansion of credit from rich (saving) to poor (spending) households. Rajan (2010) and Reich (2010) provide qualitative arguments linking income inequality to debt levels. More recently, Coibion et al. (2012) examine the direct link between income inequality and the interest rate and they document four possible channels through which interest rates may affect inequality. First, households that own firms (i.e. equity holders) may do better during periods of monetary expansion if profits rise faster than wages. Second and related to the first, households that are more integrated to financial markets, and thereby more integrated to central banks, may benefit more during monetary expansions as the price of credit falls. Third, the savings redistribution channel in which declines in inflation rates benefit savers. Lastly, they present the earnings heterogeneity channel in which wage income between low and high-income earners may differ as lower-income households are more likely to be unemployed if monetary contraction occurs and slows economic growth. They conclude that the financial segmentation channel and the portfolio channel will increase inequality when an expansionary monetary policy

\footnotetext{
${ }^{3}$ The reasons for increased household debt may be due to a "keeping up with the Jones" story, but, barring surveys of why households are spending, it would be difficult to tell why they are increasing spending/consumption.
} 
shock occurs. In contrast, the savings redistribution channel and earnings heterogeneity channels will decrease inequality after an expansionary monetary policy shock.

We are able to directly examine the response of equities and responses of aggregate household debt due to changes in interest rate using data beginning in 1919. We show that low interest rates lead to increases in equity returns, followed by increases in income inequality. As in Coibion et al., based on the sign of the response of income inequality from changes in the interest rate, we can comment on the relative contribution of the various other channels and their influence on income inequality. The reason we focus on testing for a household debt and equity channel is that debt and equities are significant components of household's balance sheets. In section II, we provide more details on how these two components evolved differently over time among the household's balance sheets at different levels of the income distribution. Overall, we believe that our paper contributes and helps clarify the relationship between income inequality and interest rates by providing a more detailed examination of the debt and equity channels.

We use data spanning from 1919 to 2009 which includes key historical periods, such as the Great Depression era and the 1950s and 1960s where inequality was quite low relative to the present. To test our channels, we estimate impulse responses from both a structural vector autoregression (SVAR) and by using Koop, Pesaran, and Potter's (1996) generalized impulse responses; results show consistency across the two different specifications of the VARs. Additionally, we also estimate Diebold and Yilmaz's (2012) generalized variance decompositions. The rest of the paper proceeds as follows: section II discusses the composition of household wealth, section III discusses our data and methodology, section IV presents our results, and section V concludes. 


\subsection{Inequality and the Composition of Household Wealth}

Understanding the evolution of the different income groups and how they hold their wealth and earn their income over time gives a better understanding behind the purpose of our three different income inequality measures. It also highlights the significance of the debt and equity channels through which monetary policy affects the distribution of income. Figure 1 shows that the share of total income going to top income groups has increased dramatically, especially for the post-1980s period.

\section{[Insert Figure 1 around here]}

Interestingly, most of the changes in the top decile are due to large changes in the top centile. The " $10 \%-1 \%$ " income group captures the income shares of the top decile, excluding the top $1 \%$. Note that we do not see large changes in the income shares of this group over time. The " $10 \%$ $1 \%$ " share increased from $24.61 \%$ in 1980 to $26.24 \%$ in 2007 . On the other hand, the income share of the top $1 \%$ increased from $10 \%$ to $23.5 \%$ over the same period. Within the top $1 \%$ group, it is the top $0.1 \%$ that has experienced the biggest increase in income. Their income share has almost quadrupled, from $3.41 \%$ in 1980 to $12.28 \%$ in 2007. Similarly, Saez and Zucman (2015) show, using data from the Survey of Consumer Finances that the top $0.1 \%$ of households' incomes have increased dramatically since the 1970s. Also, Wolff $(2012,2014)$ explains that virtually all of the income gains since 1983 have gone to the top $20 \%$ of earners. It appears from our analysis, in correspondence with other authors, that the top $1 \%$, particularly, experienced a large increase in income.

We believe differences in the way households earn and hold their wealth has contributed to increases in top income shares. Figures 2, 3, 4, and 5 show the income sources for the top $0.1 \%$, the top $1 \%$, and bottom $90 \%$ of income groups. For the bottom $90 \%$ group, most of their income 
comes from wages and very little income comes from capital gains, interest/dividends, or business equity. This has been consistent since 1989. On the other hand, more than $40 \%$ of income for the top $1 \%$ group and more than $50 \%$ of income for the top $0.1 \%$ group is from non-wages sources ${ }^{4}$.

\section{[Insert Figures 2, 3, 4, 5 around here]}

Approximately, $15 \%$ of income for the top $1 \%$ group and almost $20 \%$ of income for the top $0.1 \%$ group comes from interest or dividend income. For the bottom $90 \%$ group, this source of income is almost zero. Entrepreneurial activities provide $20 \%$ of income for the top $1 \%$ group and $30 \%$ of income for the top $0.1 \%$ group. However, for the bottom $90 \%$, only $5 \%$ of income comes from entrepreneurial activities. From Figure 5, we observe that capital gains are an important source of income for households at the top end of the income distribution; whereas, for the bottom $90 \%$, this source of income is very close to zero. On average, capital gains compose $20 \%$ of income for the top $1 \%$ group and close to $40 \%$ for the top $0.1 \%$ group. A more detailed look into the breakdown of income in the past would be valuable but data pre-dating 1989 was not readily available for the bottom $90 \%$ group from the Survey of Consumer Finances.

Furthermore, Figure 6 decompose the balance sheet components of wealthy households and households in the bottom $60 \%$ of the income distribution. As can be seen, for the top $1 \%$ group, $80 \%$ of wealth is held in business equities, financial instruments, and liquidity assets. On the other hand, the three components represent less than $25 \%$ of wealth for the bottom $60 \%$ of households. Roughly $2 / 3$ rds of their wealth is in housing.

\footnotetext{
${ }^{4}$ Note the data source for the top $0.1 \%$ and top $1 \%$ is from the World Income Databases and the Income Compositions are the share of total income excluding capital gains. The share of wages to total income would have been even lower for these two groups if capital gains were part of total income. The shares for the bottom $90 \%$ come from our own calculations using data from the Survey of Consumer Finances.
} 
[Insert Figure 6, 7, 8, 9 around here]

From Figure 7, it can be seen that debt service from the beginning of the 1990s consistently increased until the end of 2007. It suggests that, over the last 20 years, households increased the allocation of their income to paying interest or directly paying off their debt. The figure also shows that the increase in overall debt service was mainly driven by the increases in mortgage debt service. The debt service data are aggregated data and we cannot split them based on income quintiles; however, we can still say that most of the increase in debt service comes from the households outside the top end of the income distribution. This is mainly because, for low to middle-income households, housing is their main source of wealth (as seen in Figure 6). Furthermore, as shown in Figure 8, only households in the top 10\% of the income distribution have had their debt-to-assets ratio remain constant over the last 24 years. Whereas, for the other households, increases in leverage ranged from $5 \%$ to nearly a $10 \%$ increase depending on the specific income groups. As such, increases in leverage mean increases in debt service.

The difference in how households earn their income and hold their wealth is the mechanism through which we think changes in the interest rate, asset prices, and household debt are affecting the top households differently than lower income households. Specifically, the inverse link between the interest rate and equities, followed by increases in income inequality, is driven by the fact that the top income groups earn significantly more of their income and hold more of their wealth in equities. Additionally, if the interest rate is low, this may encourage wealthier households to put even more money into stocks, further exacerbating inequality. Figure 9 clearly demonstrates this. The top $10 \%$ of households have seen over a tripling in the real value of their financial assets; whereas, the bottom $90 \%$ of households have seen hardly any increase in the value of their assets. This most likely masks the true increase in financial assets of the top $1 \%$ and top $0.1 \%$ of the 
income distribution as they are averaged out with lower earning families within the top $10 \%$ of earners. On the other hand, lower income households are then affected twofold by low interest rate environments: one, they own fewer equities so they directly miss out on higher equity returns, and, second, they receive a lower rate of return on other assets they may hold (Bank of England, 2012). Similarly, observing the fact that lower income households hold much more wealth in housing (and presumably much more mortgage debt) compared to their wealthy peers, supports our finding that positive shocks to debt lead to increases in income inequality. Thus, we believe that high levels of debt accompanied with increases in debt service have restrained the upward income mobility of the indebted households.

\subsection{Data and Methodology}

\subsubsection{Data}

Annual S\&P 500 and interest rate data were collected from the FRED database. Our annual measure of household debt data was taken from Philippon (2014). Debt was defined as the level of household debt normalized by output. ${ }^{5}$ The annual data used for our measures of inequality were obtained from The World Top Income Database due to its relatively long time series. Piketty and Saez (2001) give a detailed description on how the top income shares are estimated. The top income shares are based on tax returns data published by the Internal Revenue Service (IRS). The income definition they use is a gross income definition including all the income items reported on tax returns (prior to deductions): salaries and wages, small business and farm income, partnership and fiduciary income, dividends, interest, rents, royalties, and other small items reported as other income. Then, the income shares are estimated by dividing the income amounts accruing to each

\footnotetext{
${ }^{5}$ We used both measures of household debt available in Philippon (2014). Our results were nearly identical using either measure.
} 
top fractile by total personal income computed from the National Accounts. In this paper, we use the calculated top income shares including capital gains. ${ }^{6}$

Our first measure of inequality is probably the most familiar, the Gini coefficient, which summarizes the distribution of income into a single numerical index. It ranges between 0 to 1 , where 0 indicates perfect equality and 1 indicates that a tiny group owns all resources. One criticism about the coefficient is that it does not let us clearly understand how much income is received by different groups within the wealth distribution. Particularly, we may miss much of the changes occurring at the top of the income distribution. Therefore, we continue the analysis of income inequality by looking at the evolution of the shares of top centiles relative to the rest of income earners by constructing a Theil index using data on income shares for the top $1 \%$ and bottom $99 \%$ of income earners from the World Top Income Database. This lets us better understand the disproportionate share of growth taken by the top end of the distribution as in Piketty (2014) and Gordon and Dew-Becker (2007). Additionally, we use the inverted ParetoLorenz coefficient, which measures income inequality between the top $1 \%$ and $0.1 \%$ of income earners (Piketty and Saez (2001), Atkinson, Piketty and Saez (2011)).

The Theil index provides a measure of the discrepancies between the distribution of income and the distribution of population between groups of individuals. If all population groups have an income share equal to their population share, the overall Theil index is zero. For instance, the top 1 percent of earners would get 1 percent of income and the bottom 99 percent of earners would get 99 percent of the income. As such, the index for the top $1 \%$ was constructed as follows:

\footnotetext{
${ }^{6}$ An argument that has been raised since the publication of Piketty's book is that his data overestimates true inequality. Alvaredo (2011) shows that, in fact, most current survey based studies underestimate the true level of wealth held by top income earners.
} 


$$
\text { (1) } T=I_{\text {top } 1} \times\left|I_{\text {top } 1}-N_{\text {top } 1}\right|+I_{b 99} \times\left|I_{b 99}-N_{b 99}\right|
$$

where the I's indicated the income share of the various income percentiles and the $N$ 's indicate the size of the respective percentiles (here they would simply be 0.01 and 0.99 ). All data was collected for the 1919 to 2009 time period.

Looking at Figure 10, we can see that, relative to the other two inequality measures, the Gini coefficient has a lower variance and the slope of the series is much lower for the post 1980s period.

[Insert Figure 10 around here]

As we mentioned, this can lead the Gini coefficient to underestimate the true level of income inequality. By using three distinct measures of income inequality, we aim to show which income groups were most affected by changes in the financial variables we consider.

As mentioned above, the length of our series is important as it allows us to observe inequality throughout different historical periods. As such, changes in the tax code and treatment of different types of income is important to note. For example, the 1980s saw significant changes in tax policy and in general economic policy during the Reagan administration. Particularly, 1986 is often singled out as a groundbreaking year in the tax literature due to the significant changes brought about by the Tax Reform Act. Also, perhaps the "Reagan Revolution", lower unionization, and financial deregulation had large impacts on inequality. The "Volcker disinflation" also occurred in the early 1980s which may have affected the income distribution. Levy and Temin (2007) provide further details on many institutional changes in the U.S. for the interested reader. In light of this concern, to ensure our model is not misspecified, we test for structural breaks. 


\subsubsection{Methodology}

We consider the following 4-variable VAR $(p)$,

$$
\text { (2) } Z_{t}=\sum_{i=1}^{p} \Phi_{i} Z_{t-1}+\varepsilon_{t}
$$

such that $Z_{t}^{\prime}=\left[\Delta\right.$ Interest $_{t}, \Delta \mathrm{S} \& \mathrm{P}_{t}, \quad \Delta$ Debt, $\Delta$ Inequality $\left._{t}\right]$ where $\Delta$ Interest $_{t}, \Delta \mathrm{S} \& \mathrm{P}_{t}$, $\Delta$ Debt $_{t}, \Delta$ Inequality $_{t}$ are changes in the AAA Moody's Corporate Bond Rate ${ }^{7}$, S\&P 500, household debt as a percentage of RGDP, and the three inequality measures we consider. $\varepsilon \sim(0, \Sigma)$ is a vector of independent and identically distributed error terms. We chose to first estimate generalized impulse response functions and generalized variance decompositions that are invariant to the ordering of the variables. We subsequently estimate a SVAR using a Choleski decomposition for robustness. Diebold and Yilmaz (2012) build upon Koop, Pesaran, and Potter (1996) and develop forecast error decompositions that are invariant to the variable ordering. As such, we implement both Koop, Pesaran, and Potter (1996) and Diebold and Yilmaz (2012) in order to generate generalized impulse response functions and generalized variance decompositions.

As noted in Diebold and Yilmaz (2012), the variance decompositions allow one to assess the fraction of the $H$-step-ahead error variance in forecasting $x_{i}$ that is due to shocks to $x_{j}, \forall j \neq i$, for each $i$. Diebold and Yilmaz (2012) use the structure of Koop, Pesaran, and Potter (1996) to produce variance decompositions that are invariant to the ordering of the variables because of the use of the historically observed distribution of the errors. Given the uncertainty regarding the correct ordering of our variables, we follow Koop, Pesaran and Potter (1996) and Diebold and

\footnotetext{
${ }^{7}$ For robustness we also used interest data on the US treasuries that spanned a similar time period; however, our results were quantitatively and qualitatively similar.
} 
Yilmaz (2012) and generate generalized impulse response functions and generalized variance decompositions. Diebold and Yilmaz (2012) define the own variance shares as the fraction of the H-step-ahead error variances in forecasting $x_{i}$ that are due to shocks to $x_{i}$ for $i=1,2, \ldots \ldots, N$ and cross variance shares as the fraction of the H-step-ahead error variances in forecasting $x_{i}$ that are due to shocks to $x_{i j}$ for $i, j=1,2, \ldots \ldots, N$ such that $i \neq j$. The Koop, Pesaran, and Potter (1996) Hstep-ahead forecast error variance decompositions are

$$
\text { (3) } \theta_{i j}^{g}(H)=\frac{\sigma_{j j}^{-1} \sum_{h=0}^{H-1}\left(e_{i}^{\prime} A_{h} \sum e_{j}\right)^{2}}{\sum_{h=0}^{H-1}\left(e_{i}^{\prime} A_{h} \sum e_{i}\right)}
$$

where $\sum$ is the variance matrix for the error vector $\varepsilon, \sigma_{j j}$ is the standard deviation of the error term for the $j$ th equation, and $e_{i}$ is the selection vector, with 1 as the $i$ th element and zeros otherwise. Because the sum of the elements in each row of the variance decomposition table need not equal 1, Diebold and Yilmaz (2012) normalize each entry in the variance decomposition matrix by:

$$
\text { (4) } \tilde{\theta}_{i j}^{g}(H)=\frac{\theta_{i j}^{g}(H)}{\sum_{j=1}^{N} \theta_{i j}^{g}(H)}
$$

such that by construction $\sum_{j=1}^{N} \theta_{i j}^{g}(H)=1$. Diebold and Yilmaz (2012) then use the volatility contributions from the above generalized variance decomposition to construct the total spillover index as:

$$
\text { (5) } S^{g}(H)=\frac{\sum_{\substack{i, j=1 \\ i \neq j}}^{N} \widetilde{\theta}_{i j}^{g}(H)}{N} * 100
$$

Thus, the total spillover index measures the contribution of volatility shocks across the four variables in our VAR to the total forecast error variance. The directional volatility spillovers Diebold and Yilmaz (2012) subsequently layout provide a decomposition of the total spillovers to those coming from (or to) a particular variable. The volatility spillover by variable $i$ to all other variables $j$ is 

$\sum_{j=1}^{N} \widetilde{\theta}_{i j}^{g}(H)$
(6) $S_{i}^{g}(H)=\frac{j \neq i}{N} * 100$

Similarly, the directional volatility spillovers transmitted by variable $i$ to all other variables $j$ is

$$
\text { (7) } S_{i}^{g}(H)=\frac{\sum_{\substack{j=1 \\ j \neq i}}^{N} \widetilde{\theta}_{j i}^{g}(H)}{N} * 100
$$

The net spillover from variable $i$ to all other variables $j$ is

$$
\text { (8) } S_{i}^{g}(H)=S_{\cdot i}^{g}(H)-S_{i}^{g}(H)
$$

The net pairwise volatility spillovers, are defined as

$$
\text { (9) } S_{i}^{g}(H)=\frac{\widetilde{\theta}_{j i}^{g}(H)-\widetilde{\theta}_{i j}^{g}(H)}{N} * 100
$$

\subsection{Results}

Before estimating (2), we conduct unit root tests for all variables included in the VAR.

However, as noted above, changes in the tax code may have caused a structural breaks in the inequality time series we use. To address the concern of a structural break in the inequality series', we utilized the two-break minimum LM unit root test that endogenously determines two structural breaks $\left(T_{B}\right)$ in the level and trend developed by Lee and Strazicich (2003). All variables were found to contain unit roots and did not have structural breaks and where thus differenced. ${ }^{8}$

\subsubsection{Impulse Response Functions}

For ease of exposition, we standardized and accumulated the generalized impulse responses. Figure 11, 12, and 13 display the impulse responses from estimating (2) using our three different measures of income inequality. Figure 11 displays the responses using the Gini coefficient as the income inequality measure; Figure 12 displays the results using the Theil Index

\footnotetext{
${ }^{8}$ Results may be obtained upon request of the authors.
} 
and Figure 13 displays the results using the Inverted Pareto Coefficient. The Figures should be read such that the column variable shocks the row variable.

[Insert Figures 11, 12, and 13 around here]

Note, that while the point estimates are all negative, only for income inequality represented by the Top $1 \%$ Thiel index do changes in the interest rate have a statistically significant affect. The result suggest that a positive one standard deviation shock to the interest rate has a statistically significant, negative impact on income inequality which is approximately 0.25 standard deviations after five years. In contrast, it implies that expansionary monetary policy increases income disparity between the top $1 \%$ and the bottom $99 \%$ income groups. One possible reason we may not see similar effects with the Gini coefficient and the inverted Pareto coefficient is that these two measures compare income groups that are more similar than different: the Gini primarily captures lower and middle income changes while the inverted Pareto coefficient captures changes at the very top of the income distribution. As we presented in Section II, households lower in the wealth distribution hold most of their wealth in housing. Alternatively, higher centiles hold little of their wealth in housing. Part of the reason we may see a significant response, particularly from the top $1 \%$ Theil index, is that an increase in the interest rate may discourage lower wealth households from borrowing excessively while, simultaneously, reducing the amount wealthier households borrow (as it is more costly to borrow) and invest into equities or other investment opportunities which would tend to compress inequality.

Note in the second column of Figures 11, 12, and 13 that positive shocks in the stock market show statistically significant effects across the three measures of income inequality. Per one standard deviation increase in stock market returns, the Gini coefficient increases contemporaneously by 0.4 standard deviations. The Top $1 \%$ Theil index and the inverted Pareto 
coefficient increase by approximately 0.5 standard deviations. This seems intuitive given that higher income individuals derive a higher portion of their income from interest rate sensitive assets. Put another way, high income earners have a higher interest rate elasticity of income than those at the bottom of the income distribution. Moreover after five years, all three income inequality measures suggest that income inequality has increased by over two standard deviations.

From the first column, we can see that positive shocks in interest rates have an adverse effect on the stock market and household debt. Bordo and Lane (2013) document that "loose" monetary policy impacts asset prices positively and significance remains across different subperiods. Interestingly, positive shocks in household debt as well as income inequality (across all three measures) have a statistically significant effect on stock returns by 0.25 and 1.0 standard deviations. This suggests that equity markets benefit from increased household debt as well as increased income inequality.

Note in the third column of Figures 11,12 and 13 that a one standard deviation increase in household debt leads to statistically significant increases in income inequality across all three measures. After five years, income inequality is 2 standard deviations higher using IPAR and the $1 \%$ Theil index and 1.25 standard deviation higher using the Gini coefficient. The positive response of income inequality from increases in debt and equities is consistent with the idea that that top earners use a substantial portion of their income to accumulate financial wealth through loans to those at the low end of the income distribution as in Kumhof and Ranciere (2013).

One criticism of Generalized Impulse Responses is that, if the responses are highly correlated, the shocks are almost impossible to interpret reasonably. As such, as a robustness test, we estimated (2) using an orthogonal decomposition of the covariance. Figures 14-16 display the 
results from estimating (2) using a Choleski decomposition. As can be seen, the impulse response functions are almost identical to the generalized impulse response functions in Figures 11-13.

\subsubsection{Generalized Variance Decompositions}

Table 1 Panel A displays the Diebold and Yilmaz (2012) generalized variance decompositions using the Gini coefficient as the measure of inequality. As can be seen in the last column of Table 1 Panel A, a substantial portion of the variation in the stock market, household leverage, and the Gini coefficient are attributed to the other variables in the VAR. $4.4 \%$ of the variation in the stock market returns is accounted for by interest rates, $6.6 \%$ by household leverage, and $27.8 \%$ by the Gini coefficient. As can be seen in row 3 of Table 1 Panel A, $13.5 \%$ of the variation in household debt is attributed to interest rates, $6.5 \%$ to the stock market, and $3.9 \%$ to the Gini coefficient. In row 4, note that $17.3 \%$ of the variation in the Gini coefficient is explained by the stock market, $2.6 \%$ is explained by household leverage, and $0.3 \%$ is explained by interest rates. In sum, $20 \%$ of the variation in the Gini coefficient is explained by the financial variables in the VAR. The Gini coefficient accounts for a total of $18 \%$ of the variation in the other variables in Table 1 Panel A. As discussed before, the Gini coefficient is more sensitive to changes in the lower to middle income groups. If these groups have seen relatively little movement in income/wealth over broad sections of time, then this measure may not fully capture changes at the top of the income distribution. Still, given the limitations of the Gini coefficient, we see some evidence that equity markets matter in regards to inequality.

Table 1 Panel B displays the Diebold and Yilmaz (2012) generalized variance decompositions using the Top 1\% Theil index as the measure of inequality. As can be seen in the last column of Table 1 Panel B, much of the variation in the stock market, household leverage, and Top $1 \%$ Theil index is attributed to the other variables in the VAR. $4.6 \%$ of the variation in stock market returns is accounted for by interest rates, $4.9 \%$ by household leverage, and surprisingly, 
$28.4 \%$ by the Top $1 \%$ Theil index measure. As can be seen in row 3 of table $1,11.7 \%$ of the variation in household debt is attributed to interest rates, $5.3 \%$ to the stock market, and $9 \%$ to the Top $1 \%$ Theil index. In row 4 of Table 4 , note that $18.2 \%$ of the variation in the Top $1 \%$ Theil index is explained by the stock market, $8.8 \%$ is explained by household leverage, and $2.7 \%$ is explained by interest rates. In sum, $30 \%$ of the variation in the Top $1 \%$ Theil index is explained by the financial variables in the VAR.

Our inequality measure accounts for a total of $30 \%$ of the variation in the other variables in Table 1 Panel B. Recall that the Top 1\% Theil index is capturing the discrepancy between the top $1 \%$ and bottom $99 \%$ of earners. Note that the income inequality measures account for $28.4 \%$ of the variation in the stock market returns. This provides support for the idea that the top $1 \%$ participate more in the stock market meaning, that as more income is distributed to the top $1 \%$, more income flows into the stock market. Additionally, note that household debt and stock markets explain a fairly large amount of variation in the Top 1\% Theil index, providing evidence for an equity and debt channel in regards to inequality. In addition, interest rates explain a large part of household debt, further supporting the debt channel of monetary policy impacting income inequality.

Table 1 Panel C displays the generalized variance decompositions of income inequality using the inverted Pareto coefficient as the measure of inequality. As seen in the last column of Table 1 Panel C, other variables explain $37 \%$ of variation in the stock market, with $5.5 \%$ attributed to the interest rate, $5.9 \%$ attributed to household leverage, and $25.3 \%$ attributed to the inverted Pareto coefficient. In row 3 of Table 1 Panel $\mathrm{C}$, we see that $12.4 \%$ of the variation in household leverage is attributed to the interest rate, $5.9 \%$ is attributed to the stock market, and $5.9 \%$ is attributed to the inverted Pareto coefficient. In total, $24 \%$ of the variation in household leverage is explained by 
other variables. In row 1 we see that $3.3 \%$ of the variation in the inverted Pareto coefficient is explained by the interest rate, $16.7 \%$ is explained by the stock market, and $7 \%$ is explained by household leverage. Overall, $27 \%$ of the variation in the inverted Pareto coefficient is explained by the financial variables. Correspondingly, the inverted Pareto coefficient explains roughly $35 \%$ of the variance in the financial variables

\subsection{Conclusion}

We have provided a long run analysis describing the relationship between three key financial variables (interest rates, household debt, and equity returns (S\&P 500)) and three measures of income inequality. We believe the longer time period from 1919 to 2009 gives us an advantage relative to other studies because the longer span of data allows us to observe the longrun response of inequality. For instance, many studies start their analysis in the 1970s or 1980s which misses key historical periods, such as the Great Depression era and the 1950s and 1960s where inequality was quite low relative to the present. In addition, we provide evidence for the different channels affecting inequality by analyzing how households earn their income and where they hold their income as wealth. There may be additional explanations and our analysis is an attempt to help shed light on a few potential causes of inequality. Using Philippon's (2014) new household debt we show that the stock market and household debt have significant effects on income dispersion in the United States. Interest rates have a direct effect only when we consider the Top $1 \%$ Thiel index.

In summary, our results document that increased household debt and equities are inversely related to interest rates and associated with higher levels of income inequality. This provides supporting evidence for Kumhof and Ranciere's (2013) debt-to-income inequality hypothesis and Stiglitz's (2015) equity-to-income inequality hypothesis. Also, we document a direct link between increases in income inequality, defined as the income disparity between the top $1 \%$ and bottom 
99\% income groups, and low interest rates. Our results suggest that low interest rates can exacerbate income inequality primarily because high income households derive a larger portion of their income from interest rate sensitive assets rather than wages. Based on our results, it seems that the financial segmentation channel and the portfolio channel that Coibion et al. document dominate the savings redistribution and earning heterogeneity channels. However, as in their paper, it is impossible from our data to determine precisely which channels are being affected. 


\subsection{Figures and Tables}

Figure 1.1 Top Income Shares

\section{Top Income Shares}

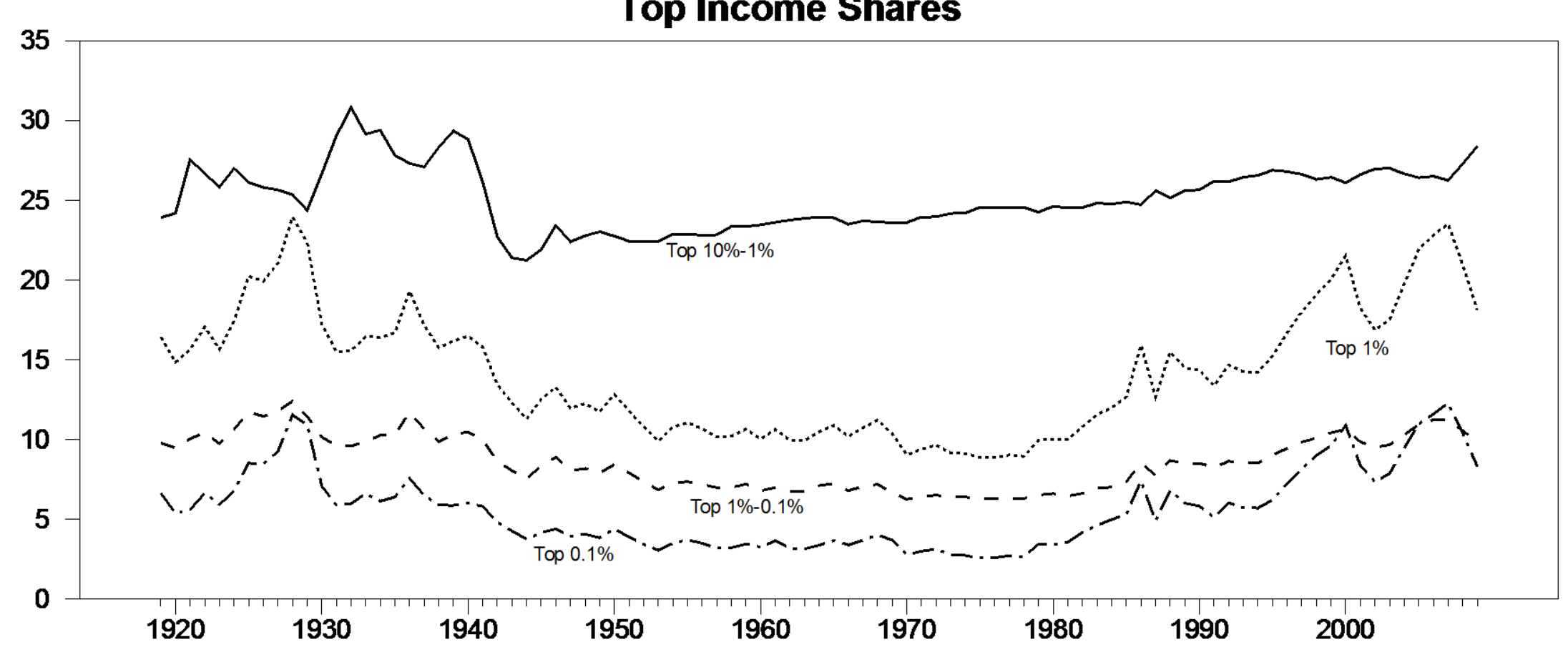




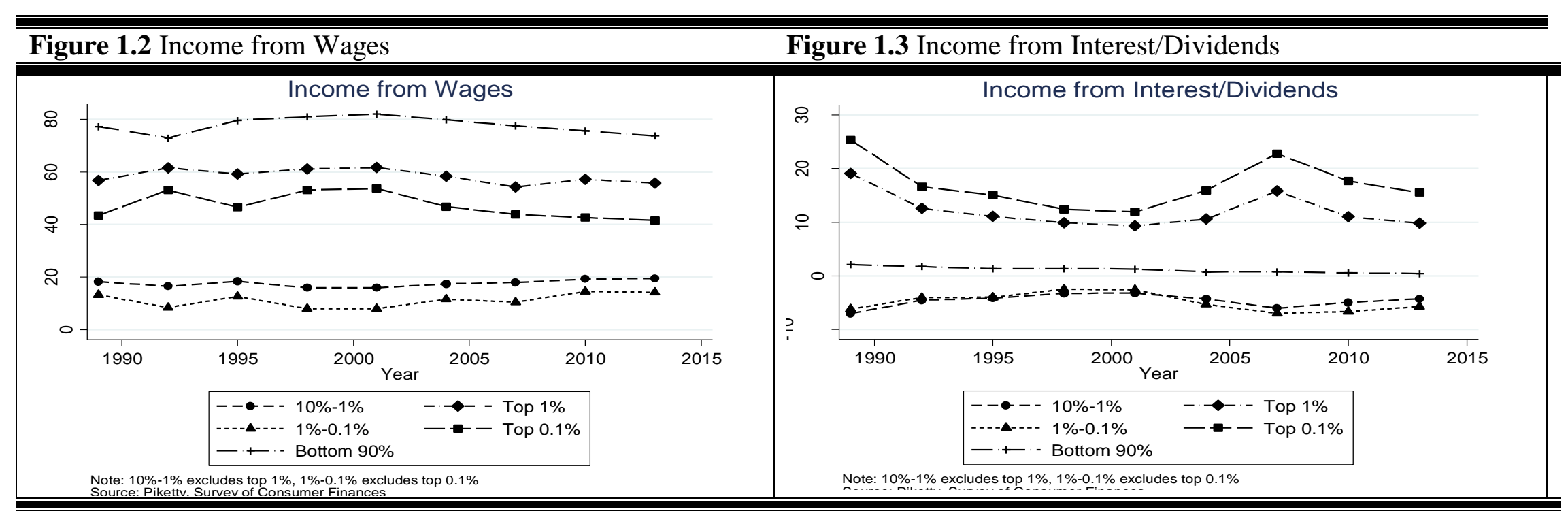

\section{Figure 1.4 Income from Entrepreneurship}

Figure 1.5 Income from Capital Gains

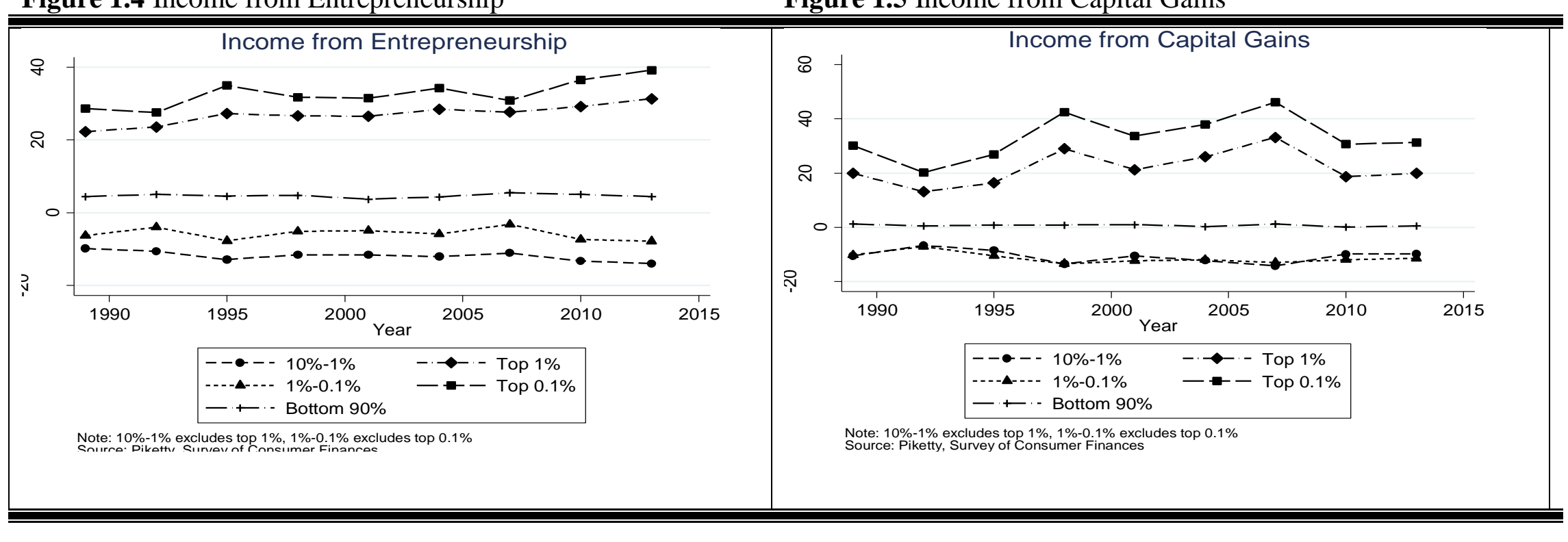




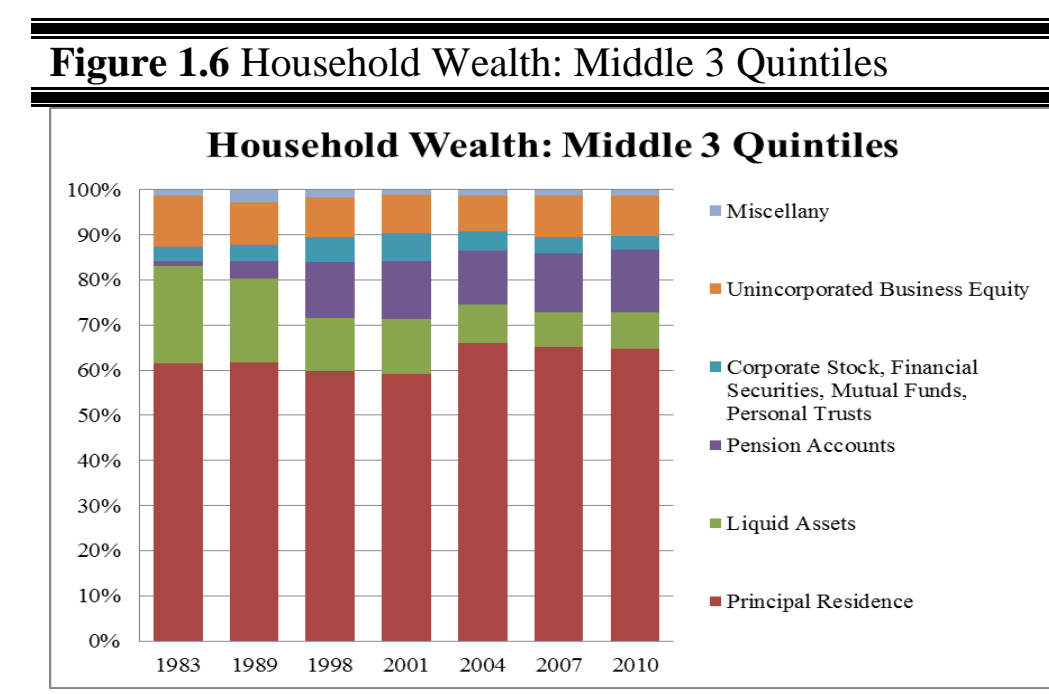

Note: The graph illustrates that the largest share of household's balance sheet at middle 3 quintiles of income distribution is represented by Housing,. Source: Wolff (2014).

\section{Figure 1.7 Debt Service Ratio}

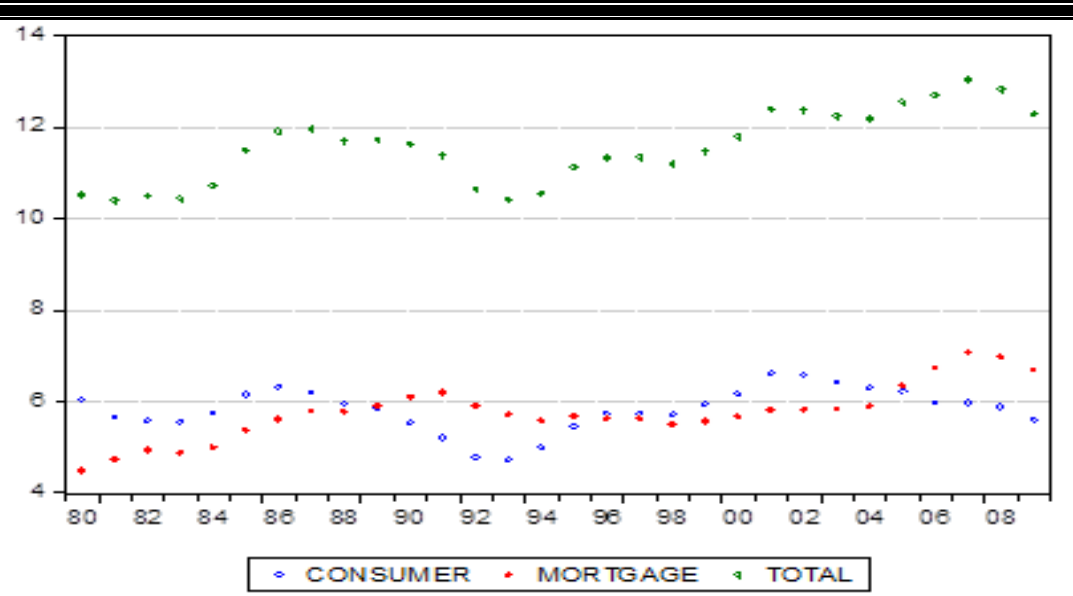

Note: Debt Service Payments are as a percentage of disposable personal income Source: Board of Governors of the Federal Reserve System (US).
Figure 1.8 Leverage Ratio by Household Income Percentile

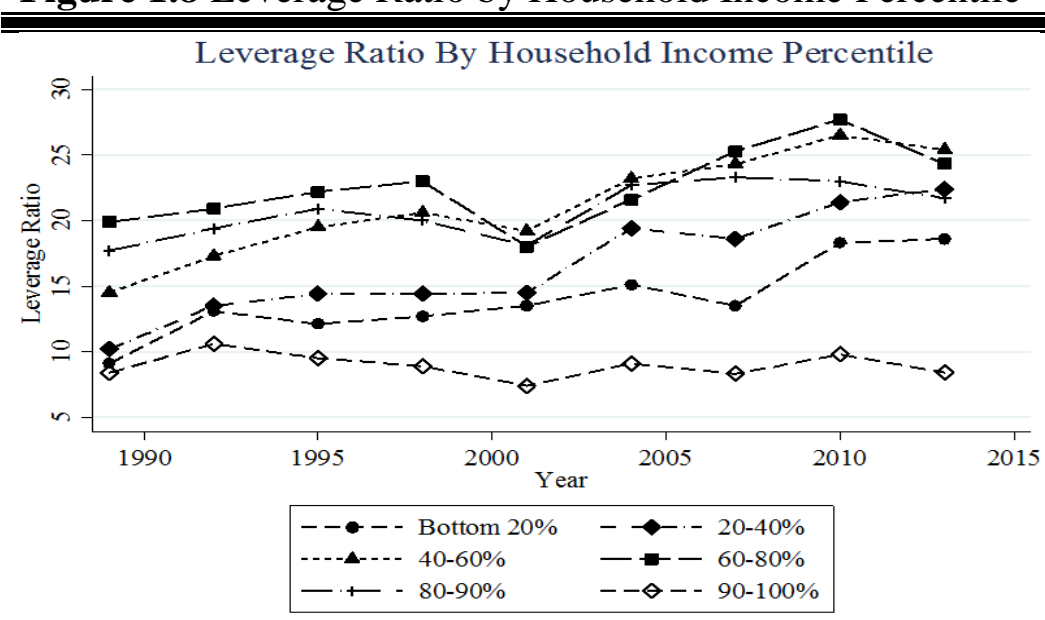

\section{Figure 1.9 Median Value of Financial Assets}

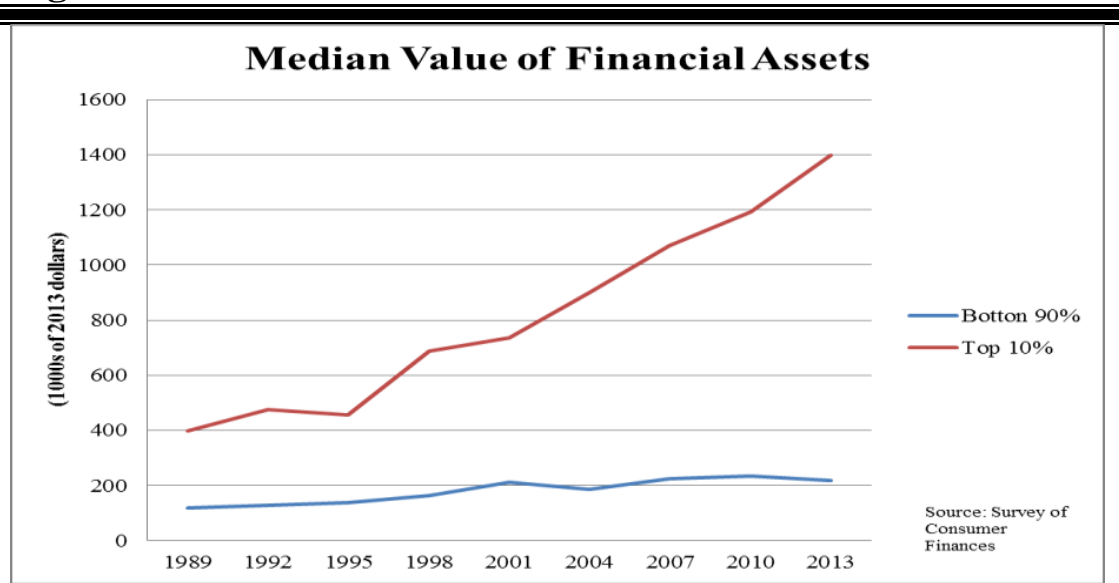


Figure 1.10 Time Series of Income Inequality Measures
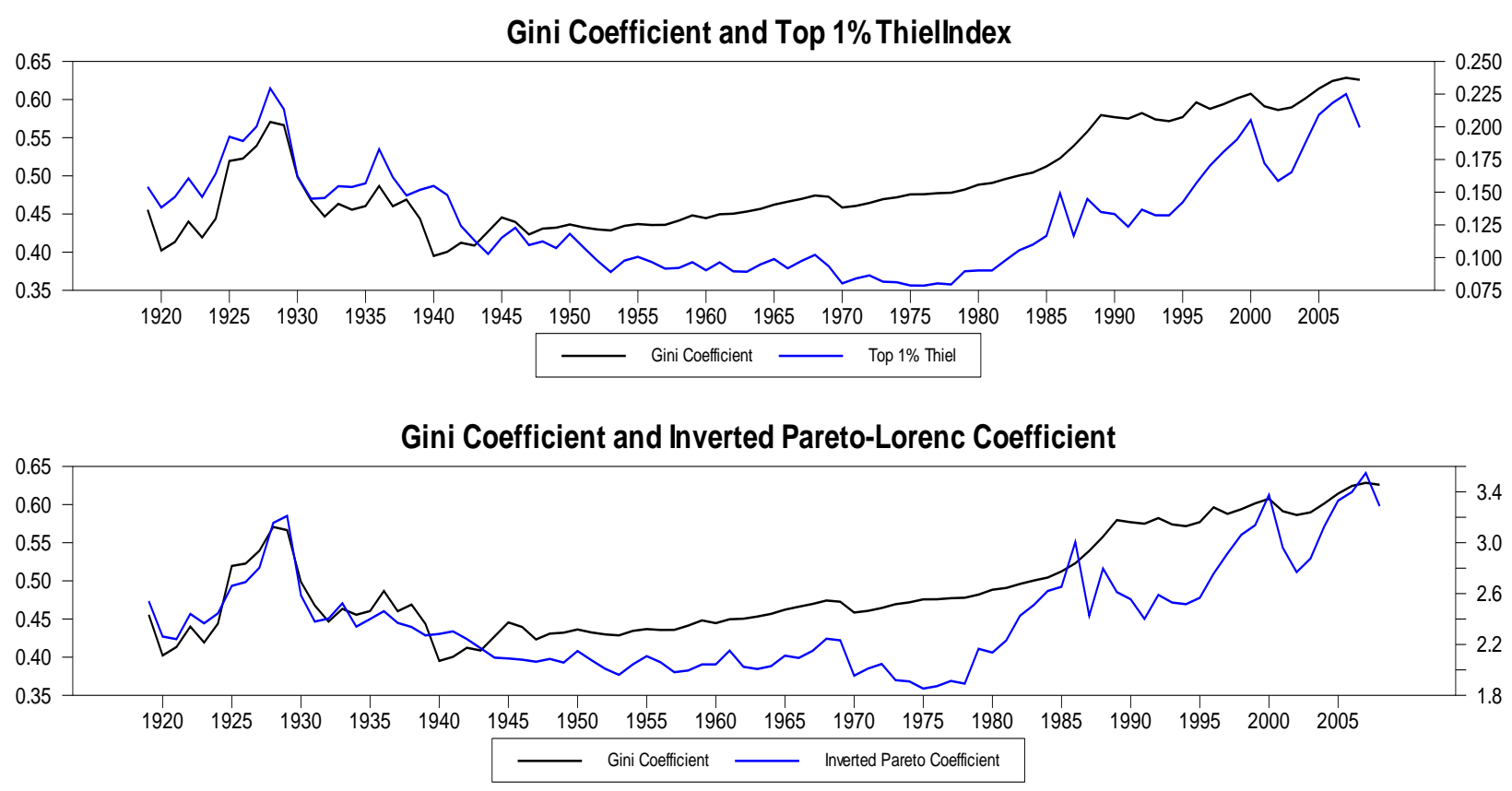
Figure 1.11 Generalized Impulse Responses Using Gini Coefficient as Income Inequality Measure

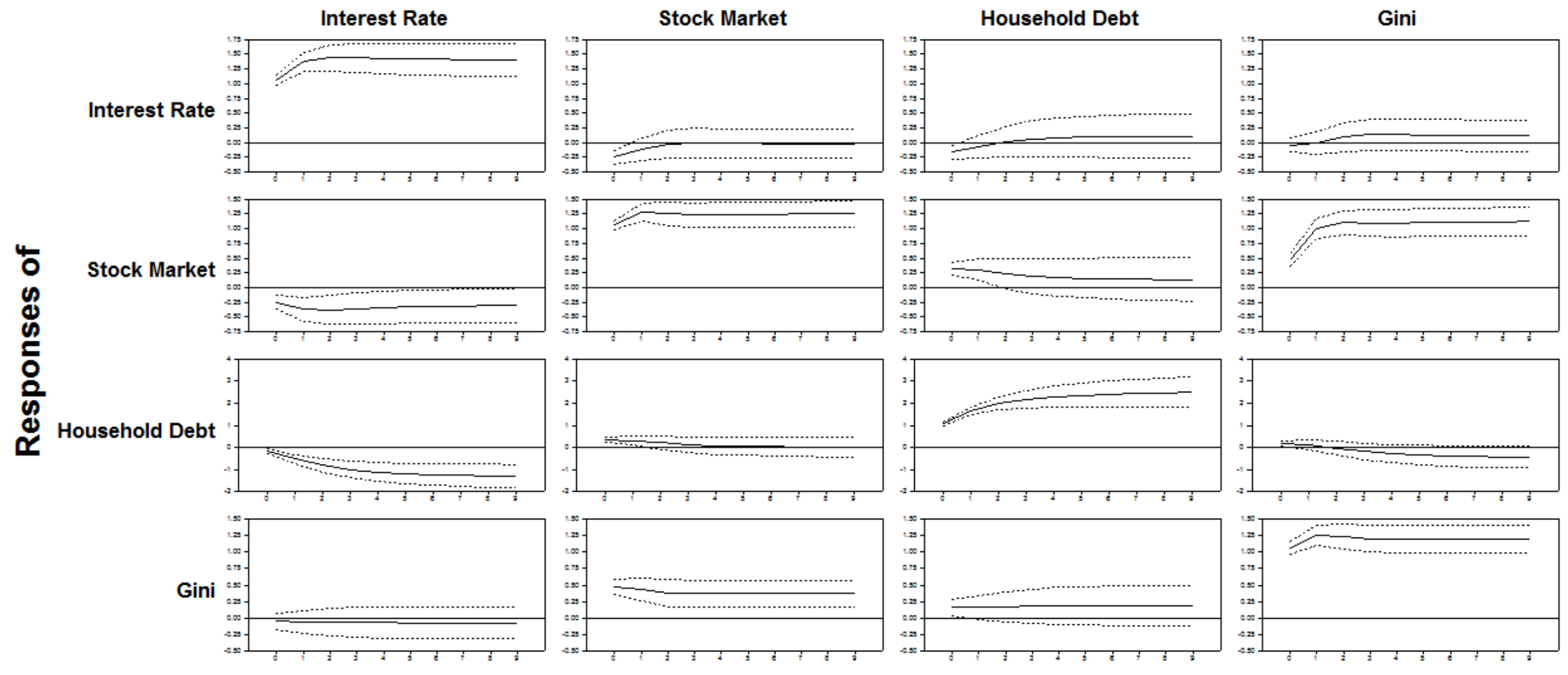


Figure 1.12 Generalized Impulse Responses Using 1\% Theil Index as Income Inequality Measure

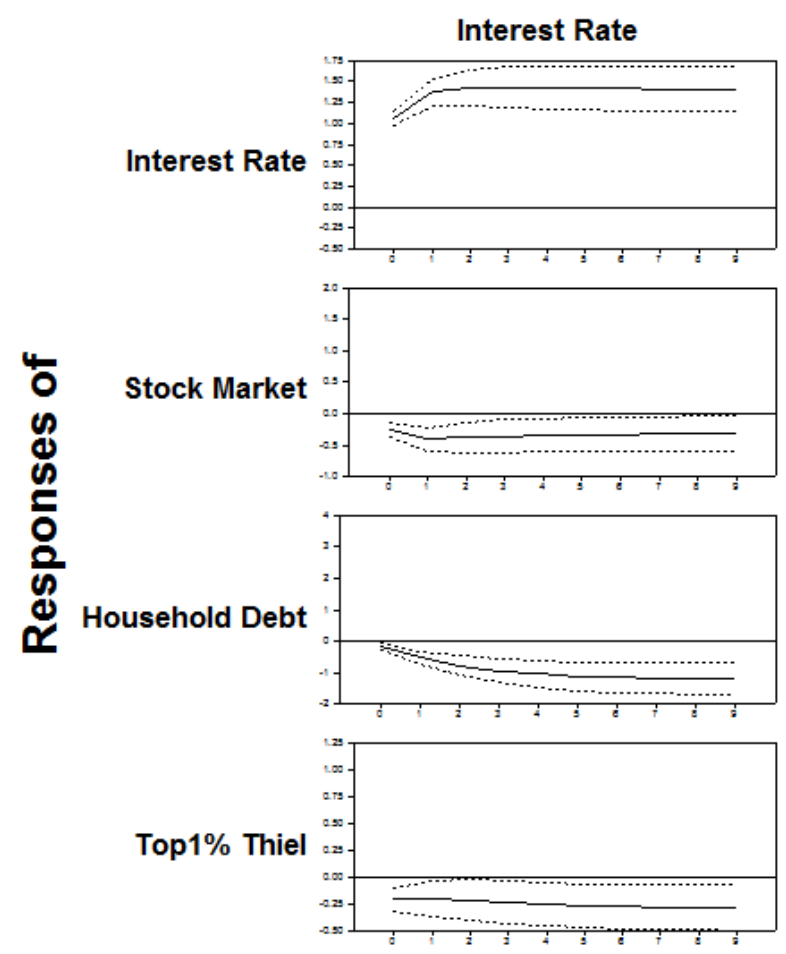

Interest Rate
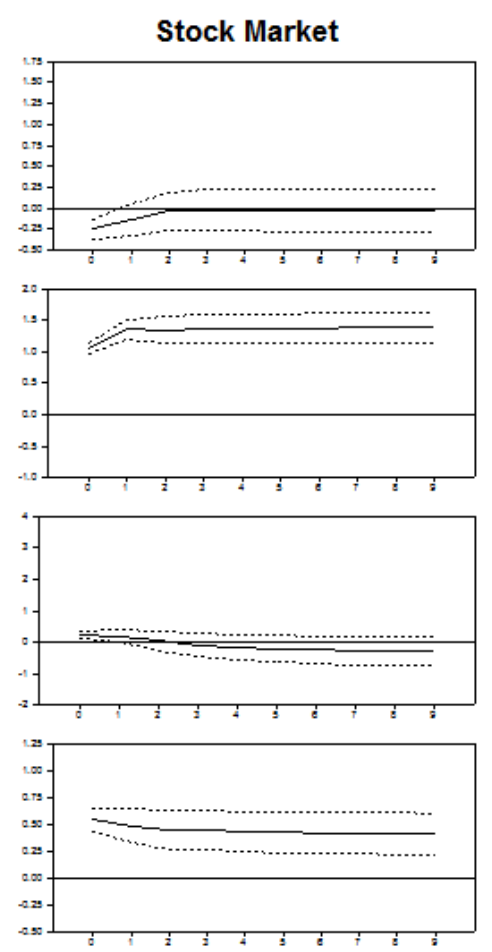

Stock Market
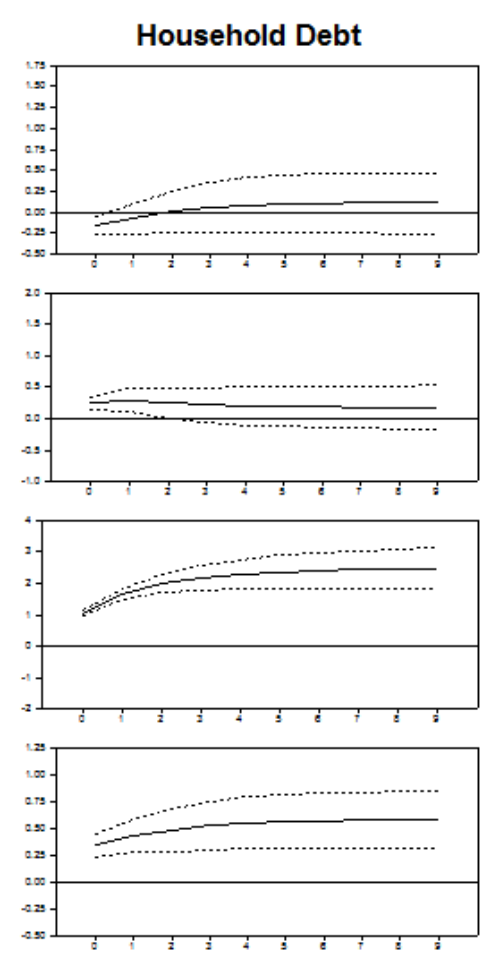

Household Debt
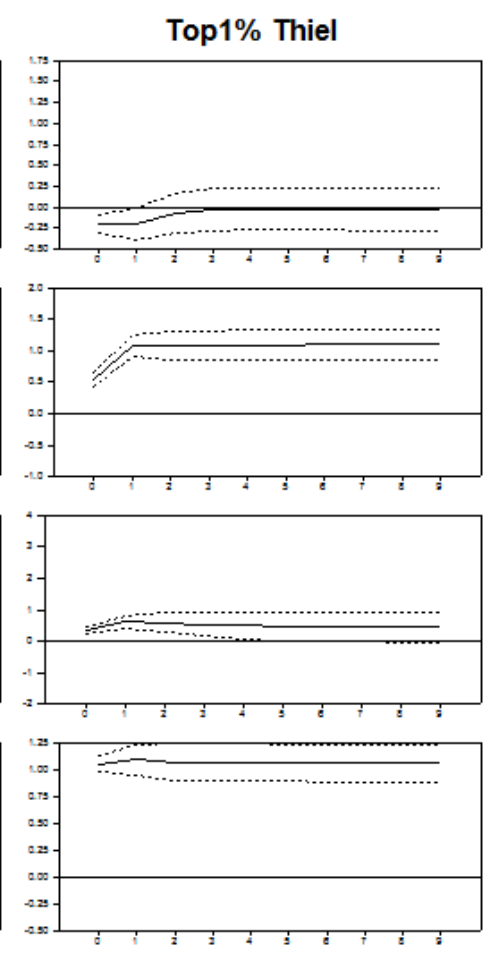

Top1\% Thiel 
Figure 1.13 Generalized Impulse Responses of Income Inequality Using Inverted Pareto Coefficient as Income Inequality Measure

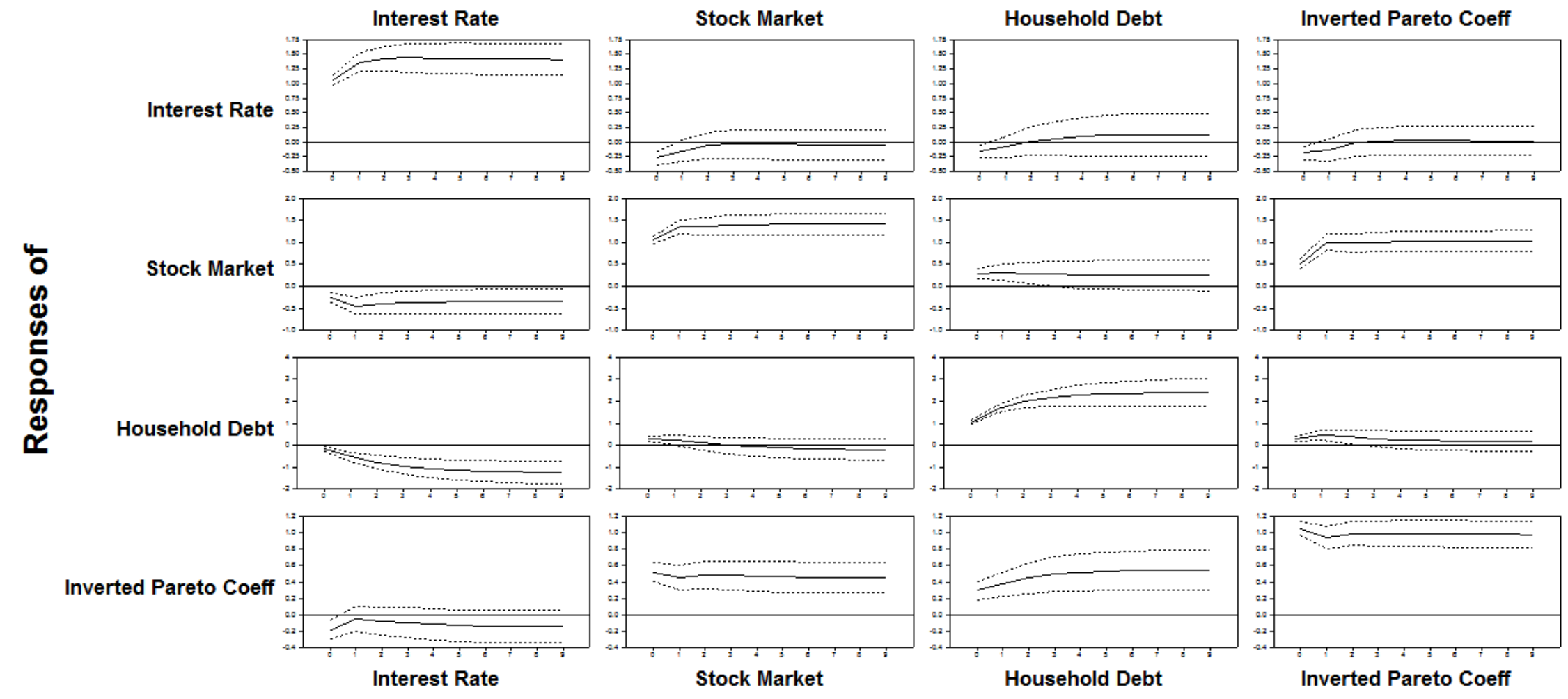


Figure 1.14 Choleski Decomposition: Impulse Responses Using Gini Coefficient as Income Inequality Measure

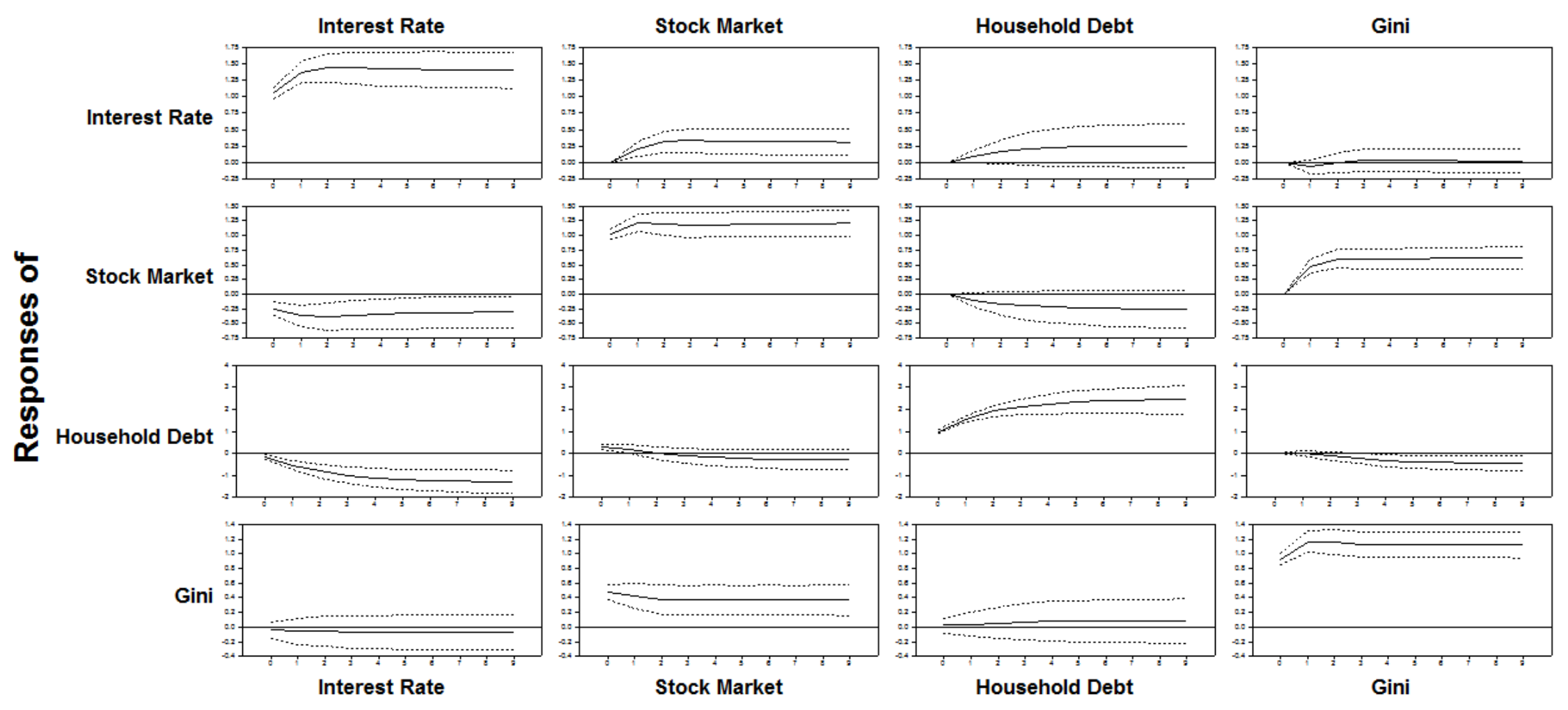


Figure 1.15 Choleski Decomposition: Impulse Responses Using 1\% Theil Index as Income Inequality Measure

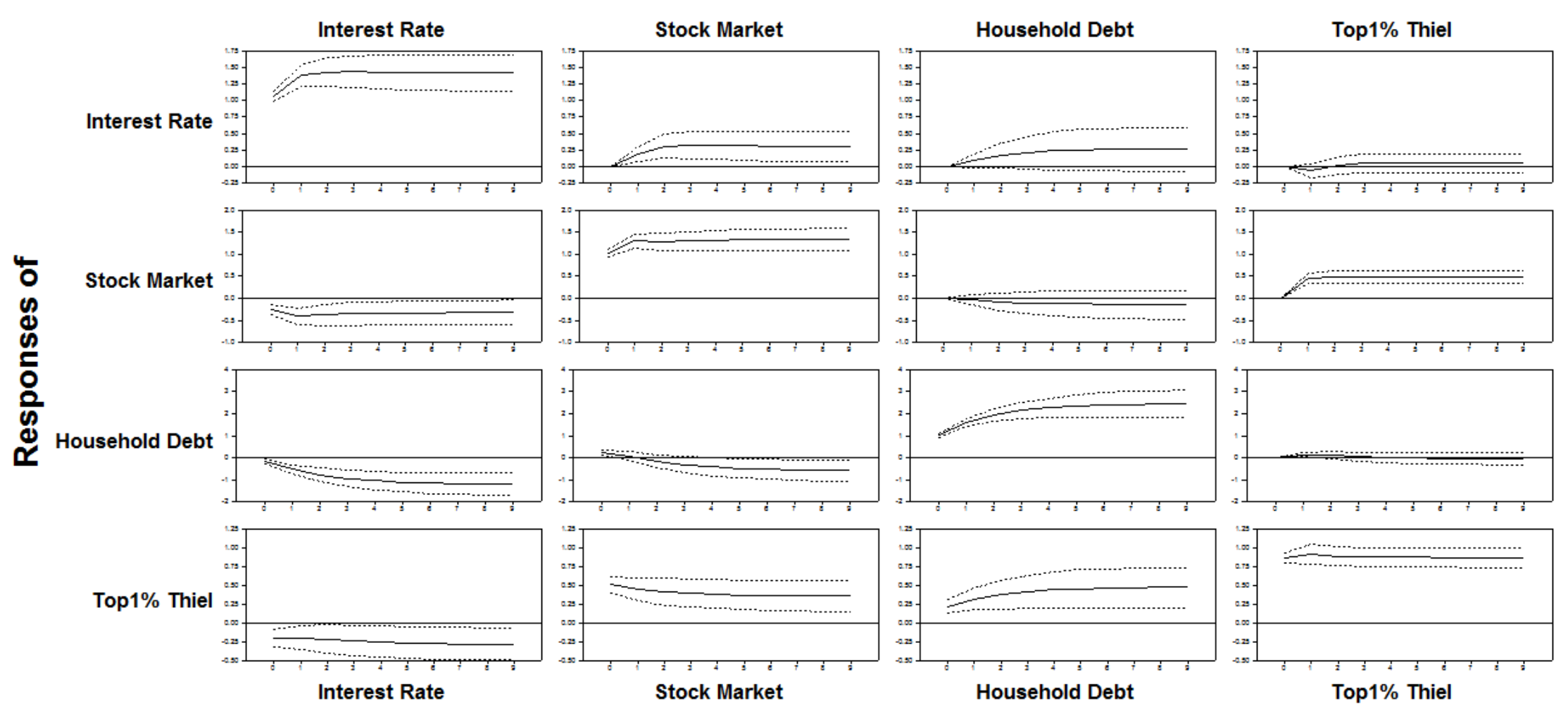


Figure 1.16 Choleski Decomposition: Impulse Responses of Income Inequality Using Inverted Pareto Coefficient as Income Inequality Measure

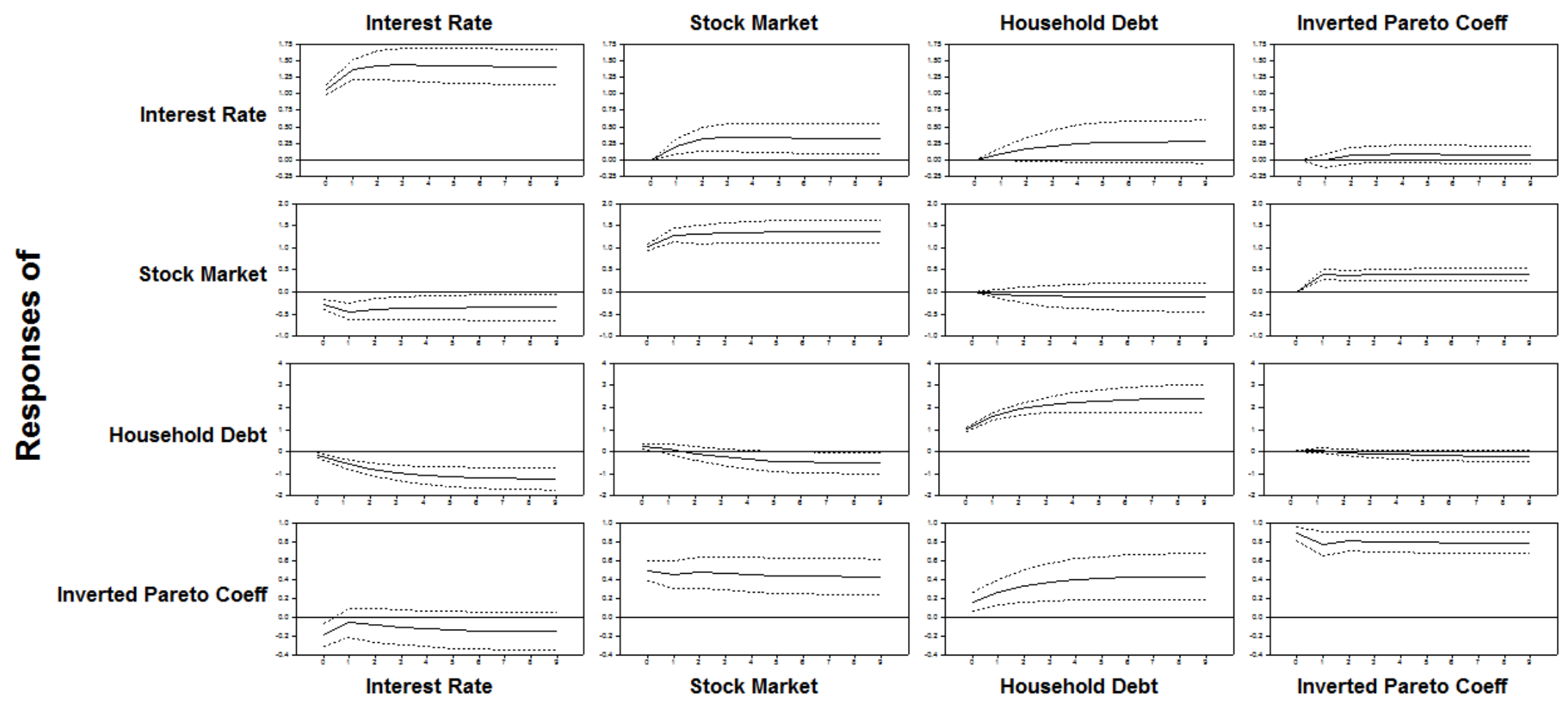


Table 1.1 (Gini) Panel A

\begin{tabular}{c|c|c|c|c|c}
\hline \hline & $\begin{array}{c}\text { Interest } \\
\text { Rates }\end{array}$ & $\begin{array}{c}\text { S\&P 500 } \\
\text { Returns }\end{array}$ & $\begin{array}{c}\text { Household } \\
\text { Debt }\end{array}$ & Gini & From Others \\
\hline Interest Rates & 88.5 & 6.8 & 3.6 & 1.1 & 11 \\
\hline S\&P 500 Returns & 4.4 & 61.2 & 6.6 & 27.8 & 39 \\
\hline Household Debt & 13.5 & 6.5 & 76.2 & 3.9 & 24 \\
\hline Gini & 0.3 & 17.3 & 2.6 & 79.8 & 20 \\
\hline Contribution to Others & 18 & 31 & 13 & 33 & \\
\hline \hline
\end{tabular}

Table 1.2 (Top 1\% Thiel Index) Panel B

\begin{tabular}{c|c|c|c|c|c}
\hline \hline & $\begin{array}{c}\text { Interest } \\
\text { Rates }\end{array}$ & $\begin{array}{c}\text { S\&P 500 } \\
\text { Returns }\end{array}$ & $\begin{array}{c}\text { Household } \\
\text { Debt }\end{array}$ & $\begin{array}{c}1 \% \text { Theil } \\
\text { Index }\end{array}$ & From Others \\
\hline Interest Rates & 86.2 & 6.5 & 3.2 & 4.0 & 14 \\
\hline S\&P 500 Returns & 4.6 & 62.1 & 4.9 & 28.4 & 38 \\
\hline Household Debt & 11.7 & 5.3 & 74.0 & 9 & 26 \\
\hline 1\% Theil Index & 2.7 & 18.2 & 8.8 & 70.3 & 30 \\
\hline Contribution to Others & 19 & 30 & 17 & 41 & \\
\hline \hline
\end{tabular}

Table 1.3 (IPAR) Panel C

\begin{tabular}{c|c|c|c|c|c}
\hline \hline & $\begin{array}{c}\text { Interest } \\
\text { Rates }\end{array}$ & $\begin{array}{c}\text { S\&P 500 } \\
\text { Returns }\end{array}$ & $\begin{array}{c}\text { Household } \\
\text { Debt }\end{array}$ & $\begin{array}{c}\text { Inverted } \\
\text { Pareto } \\
\text { Coeff. }\end{array}$ & From Others \\
\hline Interest Rates & 86 & 7.2 & 3.4 & 3.4 & 14 \\
\hline S\&P 500 Returns & 5.5 & 63.3 & 5.9 & 25.3 & 37 \\
\hline Household Debt & 12.4 & 5.9 & 75.8 & 5.9 & 24 \\
\hline Inverted Pareto Coeff. & 3.3 & 16.7 & 7 & 73 & 27 \\
\hline Contribution to Others & 21 & 30 & 16 & 35 & \\
\hline
\end{tabular}




\section{Yield Spread and the Income Distribution}

\subsection{Introduction}

"Historically, the slope of the yield curve has been such a reliable predictor of economic conditions that economists at the New York and Cleveland Federal Reserve banks use it to calculate the probability of recession".

The yield spread (slope of the yield curve) has historically been used as a gauge to measure the risk to bond investors of unexpected inflation. However, standard asset pricing suggests that the yield spread is also a good proxy for the "state" of the economy. During periods in which the economy is expected to be performing well, the yield spread will be higher than in time periods in which economic performance is expected to be poor. Figure 1 displays the yield spread, the difference between 10-year treasury bonds and 1-month treasury bills, over much of the last century along with NBER recession dates. The spread contracts before each economic downturn, including the recession beginning in 2007. The rationale behind the identified link, according to the literature ${ }^{10}$, is explained by the following three hypotheses. The first hypothesis suggests that the link between the yield spread and expected economic conditions is driven by the effects of monetary policy. Assume that the central bank initiates monetary policy expansion by lowering short-term interest rates. Since the decreases in the rates are not permanent, agents expect the future short-term rates to be higher than the current short term rates. As such, the long term rates will decrease by less than the changes in the short term interest rates leading to an upward-sloping yield curve. Given that expansions of monetary policy are followed with increases in output, we should expect the upward sloping yield curve to be followed with economic expansions. The second

\footnotetext{
${ }^{9} \mathrm{http} / / / w w w . w s j . c o m / a r t i c l e s /$ why-a-recession-could-arrive-without-a-yield-curve-warning-1454754607

${ }^{10}$ (Fama and French (1989), Estrella and Hardouvelis (1991), Bonser-Neal and Morley (1997), Ozturk and Pereira (2013))
} 
hypothesis is that the relationship between the yield spread and economic conditions is influenced by the expectations of financial market participants about future economic growth. As agents start to anticipate an economic expansion, they will expect higher inflation in periods of higher growth. Thus, such expectations are likely to lead to increases in long term interest rates and upwardsloping yield curves. The third hypothesis claims that the current economic decisions of agents contribute to the positive relationship between the yield spread and subsequent economic growth. For example, an increase in expected future income creates profitable investment opportunities today. As such, market participants will take advantage of these investment opportunities through borrowing and issuing bonds. Investments are typically long term, leading the bond issues to also be long term. An increase in the supply of longer term bonds reduces their price and increases their yield. Long-term rates will rise relative to short-term rates, and the yield curve will steepen as economic conditions are expected to improve (Bonser-Neal and Morley (1997)).

Thus, given the macroeconomic and financial informational content of the yield spread, this paper explores the predictive power of the yield spread on the changes in the income distribution. There are several different channels through which variation in the yield spread may be useful in anticipating changes in the income distribution. First, as noted above, the yield spread does imbed expectations regarding inflation. Given the importance of inflation and inflation expectations for equity markets and financial market participants, changes in the yield spread may have predictive power on changes in the income distribution through projecting the returns from financial products. ${ }^{11}$ Figure 2 clearly shows that the real value of the financial assets held by the

\footnotetext{
11 The use of the yield spread as a variable in predicting asset returns has been used extensively beginning with Fama and French (1989).
} 
top $10 \%$ of households have tripled over the last 20 years, whereas, for the bottom $90 \%$, the value of the assets barely increased.

[Insert Figure 2 around here]

Thus, changes in financial markets returns caused by changes in economic conditions (captured by the variation in the yield spread) could have an income distributional effect. Secondly, given that increases in the yield spread reflect market expectations for positive real economic activity, it is likely that not all households have the resources to take advantage of profitable investment opportunities today. Thus, variations in anticipated business conditions, approximated by the yield spread, would lead to changes in the income distribution.

Previous literature regarding the income distribution and economic conditions is vast. However, it has primarily concentrated around the contemporaneous relationship between income inequality and ex-post economic growth, by mainly addressing the question of how the income distribution effects overall economic growth. Persson and Tabellini (1991) show that, for a one standard deviation (0.07) increase in the income share of the top 20\%, the average annual growth rate in GDP decreases by approximately half a percentage point. Similarly, Pak Hung Mo (2000) concludes that income inequality has a negative effect on the GDP growth rate. Forbes (2000) challenges the belief that income inequality has a negative effect on economic growth. However, it is suggested that this might be because the paper focuses on the short and medium term (10 years) within individual countries. The positive relationship may diminish or even reverse if a longer period could have been used (Forbes (2000)). Barro (2000) concludes that the effect of income inequality on economic growth is different contingent on the state of economic development. Income inequality in poor countries hinders economic growth, but income inequality in rich countries encourages economic growth. Particularly, Barro (2000) shows that increases in 
income inequality impedes economic growth for the countries that have GDP per capita below \$2070, and supports economic growth for the countries with GDP per capita over \$2070. Partridge (2005) finds that inequality and growth are positively related, specifically the middle class measured by the middle-quintile income share (Q3) is positively related to growth. Similarly, Frank (2009) shows that the positive long-run association between inequality and growth across the US states is mainly driven by the income shares of the top $1 \%$. The estimated coefficients show that a two-standard deviation increase in the top $1 \%$ income shares would increase the long-run growth rate of real income per capita by $0.066 \%$. On the other hand, only a few studies examine the impact of business conditions on the distribution of income. It is suggested that rich households are more vulnerable to aggregate fluctuations than poorer households. Parker and Jorgensen (2009) find that a 3 percentage point decline in the growth rate of aggregate real per capita consumption of nondurables and services will lead to a decline of about 1.5 percentage points in the growth rate of real per household consumption for those in the bottom 80 percent, of around 10 percentage points for those in the top 20 percent, and of around 16 percentage points for those in the top 10 percent - all relative to trend. The reason is that the incomes of the top income groups have larger sensitivities to aggregate growth. Particularly, the incomes of the top 0.1 percent of tax units have sensitivities of about 7 to aggregate consumption growth and about 3 to aggregate income growth.

This paper contributes to the existing literature by testing how the anticipated changes in economic conditions, approximated by the yield spread, drive changes in the distribution of income. The analysis presented in this paper helps us better understand who gains from expected economic growth. The long time-series analysis, since 1927, allows for a long-term examination of changes in inequality to variations in economic conditions, estimated by the yield spread. The relationship is examined after controlling for existing economic conditions, as captured by changes in 
unemployment or changes in real disposable income. To ensure that the relationship between the yield spread and the income distribution is not driven by the realized future growth, as a robustness test, a one year forward growth rate in industrial production is included in the model. It should be noted that the significance of the yield spread as a predictor of real economic activities is well established in the literature. Estrella et al. (2000) provides a great summary of the papers that document that the yield spread helps to predict subsequent economic growth. Similarly, Wheelock and Wohar (2009) survey more recent literature, and they assert that the yield spread does predict output growth and recessions.

The significance of the yield spread as a predictor of the changes in income distribution is initially documented by implementing Clark and McCracken's (2001) out-of-sample Granger causality test. Two alternative models, one that includes the yield spread and another one that does not account for it are put to a head-to-head test. The models are estimated over the shortened span of data and the estimates are used to forecast the observations of the holdback period. The forecast errors from the two models are compared to determine the significance of the yield spread in predicting variations in the income distribution. Then, the generalized impulse responses and the generalized variance decompositions are used to link together the yield spread, financial markets, existing economic conditions, and the distribution of income under a common framework.

To preview, findings indicate that the yield spread has strong predictive power on changes in the income distribution across three different measures. Particularly, increases in the yield spread correspond with subsequent increases in top income shares, leading to increases in income inequality. Results also show that realized future growth rates in the stock market or industrial production feed into increases in income inequality. Interestingly, the results reveal that the increases in top income shares have no statistically significant impact on realized expected growth rates. 
The rest of the paper proceeds as follows. Section 2 discusses the data sources. Section 3 discusses the Clark and McCracken out-of-sample tests. Section 4 discusses the generalized variance decompositions and generalized impulse response functions and section 5 concludes.

\subsection{Data}

The yield spread is defined as the difference between long term interest rates (10-years) from Robert Shiller's website and one-month Treasury bill rates from the WRDS database. For a robustness check, the yield spread is also defined as the difference between Moody's Seasoned AAA Corporate Bond Yield from the FRED Database and one-month Treasury bill rates. Annual S\&P 500 data are obtained from the FRED database. Unemployment rates represent the percentage of the civilian labor force that is unemployed. This data is from the FRED database and Census.gov. Data for industrial production and real disposable income are from the FRED database.

The first measure of income inequality is the Gini coefficient ${ }^{12}$, which summarizes the distribution of income into a single numerical index. It ranges between 0 and 1 , where 0 indicates perfect equality and 1 indicates that a small group owns all resources. One criticism about the coefficient is that it does not let us clearly understand how much income is received by different groups within the wealth distribution. Particularly, we may not be able to capture the changes occurring at the top of the income distribution. Therefore, income inequality is analyzed by looking at the evolution of the shares of top centiles relative to the rest of income earners by constructing a Theil index using data on income shares for the top 1\% and bottom $99 \%$ of income earners from the World Top Income Database. This allows us to better understand the disproportionate share of growth taken by the top end of the distribution as in Piketty (2014) and Gordon and Dew-Becker

\footnotetext{
${ }^{12}$ From Frank-Sommeiller-Price Series.
} 
(2007). The Theil index, as defined below, provides a measure of the discrepancies between the distribution of income and the distribution of population between groups of individuals. If all population groups have an income share equal to their population share, the overall Theil index is zero. For instance, the top 1 percent of earners would get 1 percent of income and the bottom 99 percent of earners would get 99 percent of the income. As such, the index for the top $1 \%$ was constructed as follows:

$$
T=I_{\text {top } 1} \times\left|I_{t o p 1}-N_{t o p 1}\right|+I_{b 99} \times\left|I_{b 99}-N_{b 99}\right|
$$

where the I's indicated the income share of the various income percentiles and the $N$ 's indicate the size of the respective percentiles (here they would simply be 0.01 and 0.99 ).

Additionally, the Inverted Pareto-Lorenz coefficient (IPAR), which measures income inequality between the top $1 \%$ and $0.1 \%$ of income earners is used as a third income inequality measure (Piketty and Saez (2001), Atkinson, Piketty and Saez (2011), Piketty and Saez (2001) give a detailed description on how the top income shares are estimated). The top income shares are based on tax returns data published by the Internal Revenue Service (IRS). The income definition they use is a gross income definition including all the income items reported on tax returns (prior to deductions): salaries and wages, small business and farm income, partnership and fiduciary income, dividends, interest, rents, royalties, and other small items reported as other income. Then, the income shares are estimated by dividing the income amounts accruing to each top fractile by total personal income computed from the National Accounts. In this paper, the calculated top income shares including capital gains are used. The time period analyzed is from 1927 to 2011.

Looking at Figure 3, we can see that, relative to the other two inequality measures, the Gini coefficient has a relatively lower variance and slope, particularly for the period post-1980s. 
[Insert Figure 3 around here]

As mentioned before, this can lead the Gini coefficient to underestimate the true level of income inequality. Thus, using three distinct measures of income inequality allows us to better predict which income groups are mostly expected to be affected by future changes in economic conditions.

\subsection{Clark and McCracken Out of Sample Tests and Results}

The significance of the yield spread in predicting income inequality is initially tested by estimating Clark and McCracken 1-step ahead forecasts from nested linear models. This test is done in two stages. First, forecasts of the variable of interest (income inequality) are constructed using a model that includes all three variables and then a second time excluding the variable with presumed predictive content (yield spread). Second, given the two calculated forecast errors, tests of forecast encompassing are performed. The null hypothesis is that the unrestricted model nests the restricted model, whereas the alternative hypothesis is that the unrestricted model is correct. This is more in the spirit of the definition of Granger causality that employs post-sample forecast tests rather than the standard full-sample causality test (Clark and McCraken (2001)).

Two different in-sample and out-of-sample portions are used to test for the predictive power of the yield spread on income inequality. The first portion, $\pi=1$, spans the in-sample period from 1927 - 1968 and out-of-sample period from 1969 - 2011; whereas the second portion spans the in-sample period from 1927 - 1983 and out-sample period from 1984 - 2011. Using the Akaike Information Criteria (AIC) and Bayesian/Schwarz Information Criteria (SIC), a lag of length 1 is chosen. As reported in Table 1, almost all of the encompassing tests reject the null hypothesis that the yield spread has no predictive content about changes in income inequality. This indicates that the variation in economic conditions, approximated by the yield spread, have income distributional effects. The 
results are stronger for income inequality measures that specifically capture top income shares: the Top 1\% Thiel Index and the Inverted Pareto Lorenz Coefficient (IPAR). Once the beginning of the 1980s is included as part of the in-sample period, it can be seen from Table 1 that the model that uses the Gini Coefficient as the income inequality measure improves in predicting changes in income inequality.

[Insert Table 1 around here]

The documented results are unchanged even when expected returns in the stock market are replaced with one-year realized future growth rates in industrial production ${ }^{13}$.

\subsection{Generalized Impulse Reponses and Generalized Variance Decompositions}

To identify the link between the yield spread and the income distribution the following 4variable $\operatorname{VAR}(p)$ model is estimated:

$$
Z_{t}=\sum_{i=1}^{p} \phi_{i} Z_{t-i}+\varepsilon_{t}, \quad t=1,2, \ldots, T
$$

where $Z_{t}=\left[\begin{array}{llll}y s_{t} & \Delta S \& P_{t+1} & \Delta u e_{t} & \Delta i n e q_{t}\end{array}\right]^{\prime}$ is a vector of jointly determined dependent variables: the yield spread $\left(y s_{t}\right), \mathrm{S} \& \mathrm{P} 500$ index $\left(\Delta S \& P_{t+1}\right)^{14}$, unemployment $\left(\Delta u e_{t}\right)$, and income inequality $\left(\Delta i n e q_{t}\right) . \varepsilon \sim(0, \Sigma)$ is a vector of independent and identically distributed error terms. The lag length for (1) was selected using the Bayesian/Schwarz Information Criteria (SIC), which suggested $p=1$. Again, $y s_{t}$ is defined as the difference between long term interest rates (10years) and one-month Treasury bill rates. $\Delta S \& P_{t+1}$ represents the realized expected returns in the stock market. As such, it captures future economic conditions. It also helps us to identify the stock market channel through which the yield spread might impact income inequality. For robustness,

\footnotetext{
${ }^{13}$ To save space these results are not reported in the paper, but they are available upon request.

${ }_{14} 100 *\left[\log \left(\mathrm{S} \& \mathrm{P}_{\mathrm{t}+1}\right)-\log \left(\mathrm{S} \& \mathrm{P}_{\mathrm{t}}\right)\right]$.
} 
future economic conditions are also measured using a one-year forward growth rate in industrial production. $\Delta u e_{t}$ represents changes in unemployment and is used to control for current business cycle conditions. Changes in real disposable income is used as another measure to control for current business conditions. Thus, controlling for future and current business conditions allows us to explicitly capture the response of income inequality to variations in the yield spread.

Following Koop, Pesaran, and Potter (1996), generalized impulse response functions are generated. Therefore, defining the known history of the economy up to time t-1 by the nondecreasing information set $\Omega_{t-1}$, the generalized impulse function of $Y_{t}$ at horizon $\mathrm{n}$ is defined by

$$
G I_{z}\left(n, \delta, \Omega_{t-1}\right)=E\left(Z_{t+n} \mid \varepsilon_{t}, \Omega_{t-1}\right)-E\left(Z_{t+n} \mid \Omega_{t-1}\right)
$$

where $\delta$ represents the shocks hitting the economy, and assuming $\varepsilon_{t}$ has a multivariate normal distribution following Koop et al. (1996) it can be shown that

$$
E\left(\varepsilon_{t} \mid \varepsilon_{j t}=\delta_{j}\right)=\left(\sigma_{1 j}, \sigma_{2 j}, \ldots, \sigma_{m j}\right)^{\prime} \sigma_{j j}^{-1} \delta_{j}=\sum e_{j} \sigma_{j j}^{-1} \delta_{j}(7)
$$

Therefore, the $m \times 1$ vector of the (unscaled) generalized impulse response of the effect of a shock in the jth equation at time $\mathrm{t}$ on $z_{t+n}$ is given by

$$
\left(\frac{A_{n} \Sigma e_{j}}{\sqrt{\sigma_{j j}}}\right)\left(\frac{\delta_{j}}{\sqrt{\sigma_{j j}}}\right), \quad n=0,1,2, \ldots(8)
$$

Letting $\delta_{j}=\sqrt{\sigma_{j j}}$, the scaled generalized impulse response function by:

$$
\psi_{j}^{g}(n)=\sigma_{j j}^{-\frac{1}{2}} A_{n} \Sigma e_{j},=0,1,2, \ldots,(9)
$$

which measures the effect of one standard error shock to the jth equation at time $t$ on expected values of $Z_{t}$ at time $t+n$. 
Then following Diebold and Yilmaz (2012) the generalized variance decompositions are estimated, which allow one to assess the fraction of the $H$-step-ahead error variance in forecasting $z_{i}$ that is due to shocks to $z_{j}, \forall j \neq i$, for each $i$. Diebold and Yilmaz (2012) use the structure of Koop, Pesaran, and Potter (1996) to produce variance decompositions that are invariant to the ordering of the variables because of the use of the historically observed distribution of the errors. Diebold and Yilmaz (2012) define the own variance shares as the fraction of the $\mathrm{H}$-step-ahead error variances in forecasting $z_{i}$ that are due to shocks to $z_{i}$ for $i=$ $1,2, \ldots \ldots, N$ and cross variance shares as the fraction of the H-step-ahead error variances in forecasting $z_{i}$ that are due to shocks to $z_{i j}$ for $i, j=1,2, \ldots \ldots, N$ such that $i \neq j$. The Koop, Pesaran, and Potter (1996) H-step-ahead forecast error variance decompositions are

$$
\theta_{i j}^{g}(H)=\frac{\sigma_{j j}^{-1} \sum_{h=0}^{H-1}\left(e_{i}^{\prime} A_{h} \Sigma e_{j}\right)^{2}}{\sum_{h=0}^{H-1}\left(e_{i}^{\prime} A_{h} \Sigma e_{i}\right)}(11)
$$

where $\sum$ is the variance matrix for the error vector $\varepsilon, \sigma_{j j}$ is the standard deviation of the error term for the $j$ th equation, and $e_{i}$ is the selection vector, with one as the $i$ th element and zeros otherwise. Because the sum of the elements in each row of the variance decomposition table need not equal 1, Diebold and Yilmaz (2012) normalize each entry in the variance decomposition matrix by:

$$
\tilde{\theta}_{i j}^{g}(H)=\frac{\theta_{i j}^{g}(H)}{\sum_{j=1}^{N} \theta_{i j}^{g}(H)}(12)
$$

such that by construction $\sum_{j=1}^{N} \theta_{i j}^{g}(H)=1$. Diebold and Yilmaz (2012) then use the volatility contributions from the above generalized variance decomposition to construct the total spillover index as: 


$$
S^{g}(H)=\frac{\substack{\sum_{i, j=1}^{N} \widetilde{\theta}_{i j}^{g}(H) \\ i \neq j}}{N} * 100
$$

Thus, the total spillover index measures the contribution of volatility shocks across the four variables in our VAR to the total forecast error variance. The directional volatility spillovers Diebold and Yilmaz (2012) subsequently layout provides a decomposition of the total spillovers to those coming from (or to) a particular variable. The volatility spillover by variable $i$ to all other variables is $j$ is

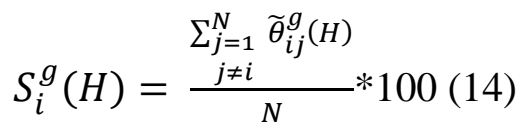

Similarly, the directional volatility spillovers transmitted by variable $i$ to all other variables $j$ is

$$
\begin{aligned}
& \sum_{j=1}^{N} \widetilde{\theta}_{j i}^{g}(H) \\
& S_{i}^{g}(H)=\frac{j \neq i}{N} * 100(15)
\end{aligned}
$$

The net spillover from variable $i$ to all other variables $j$ is

$$
S_{i}^{g}(H)=S_{\cdot i}^{g}(H)-S_{i \cdot}^{g}(H)(16)
$$

The net pairwise volatility spillovers, are defined as

$$
S_{i}^{g}(H)=\frac{\widetilde{\theta}_{j i}^{g}(H)-\widetilde{\theta}_{i j}^{g}(H)}{N} * 100(17)
$$

\subsubsection{Results}

a) Generalized Impulse Response Functions

Figures 4, 5, and 6 show the generalized impulse responses of income inequality using the three measures. For ease of exposition, the impulse responses are standardized and accumulated.

[Insert Figures 4, 5, 6 around here]

A positive one standard deviation shock to the yield spread has a contemporaneous, statistically significant, positive effect on income inequality. The impact ranges from 0.4 to 0.75 standard 
deviations, depending on the income inequality measure used. The largest impact is for the Gini Coefficient. The point estimates remain positive and significant over the ten-year period across the three measures. The results indicate that the subsequent improvements in economic conditions are beneficial mainly for the households at the top end of the income distribution. This is also documented by the positive effect of expected returns in financial markets on income inequality. Particularly, a one standard deviation increase in expected returns leads to approximately a 0.8 standard deviation increase in income inequality. Results are consistent across the three inequality measures and remain significant over the ten-year period. This is not a surprise given that financial assets are mainly held by wealthy households. Thus, a positive shock to financial assets should correspond with increases in top income shares. Interestingly, increases in unemployment seem to matter only for the income inequality measure represented by the Top $1 \%$ Thiel Index, where a one standard deviation shock in unemployment corresponds with a 0.2 standard deviation increase in income inequality. Changes in unemployment not affecting the other two measures of income inequality is not that surprising. The Gini coefficient is more sensitive to changes in the income shares of the households at the lower to middle income groups. These groups have barely experienced any movement in income/wealth over broad sections of time; therefore, the variation in unemployment does not have any effect on changes in income inequality, defined by the Gini coefficient. Similarly, IPAR captures the income disparity at the very top of the income distribution. Increases in unemployment not impacting the income disparity at the very top of the income distribution is not unexpected since increases in unemployment lead to losses for households mainly in the middle and bottom of the income distribution (Aaberge et al. (2000)).

To ensure that the positive relationship between the yield spread and income inequality is not being driven by the realized expected economic conditions, expected returns in stock market 
are replaced with one-year forward growth rates in industrial production (figures 7, 8, and 9). The findings confirm that the increases in the yield spread correspond with subsequent increases in income inequality, even after controlling for realized expected economic conditions. The documented empirical findings remain intact when real disposable income is used as an indicator of current business cycles. Interestingly, the findings suggest that realized future growth contributes to the growth in income inequality. Note, the positive response of income inequality to increases in the yield spread holds even when the yield spread is defined as the difference between Moody's Seasoned AAA Corporate Bond Yield from the FRED Database and one-month Treasury bill rates ${ }^{15}$.

\section{[Insert Figures 7, 8, 9 around here]}

Figures 10, 11, 12 display the generalized impulse responses of the S\&P 500 realized expected returns. In close correspondence with the literature (Fama and French (1989)), we can see that increases in the yield spread lead to positive expected returns in financial markets. A one standard deviation increase in the yield spread leads to a 0.5 standard deviation increase in expected returns. Interestingly, increases in income inequality seem to be beneficial for financial markets. For a one standard deviation increase in income inequality, expected returns in financial markets increase by approximately 0.4 standard deviations. The results are stronger when the Gini Coefficient is used as the income inequality measure, whereas for the other two measures, IPAR and the Top $1 \%$ Thiel Index, the significance of the results drops after one year. The findings suggest that, as wealthy households become richer, they accumulate more financial wealth, leading to positive returns in financial markets.

[Insert Figures 10, 11, 12 around here]

\footnotetext{
${ }^{15}$ Findings when real disposable income is used for measuring current economic conditions and for the alternative specification of the yield spread are available upon request.
} 
Similarly, results show that increases in the yield spread predict subsequent increases in the realized future growth (figures 13,14, and 15). On the other hand, the results indicate that increases in income inequality have no statistically significant impact on subsequent economic growth.

[Insert Figures 13, 14, 15 around here]

Figures 16, 17, 18 display the generalized impulse responses of unemployment. A positive one standard deviation shock to the yield spread corresponds with a 1.5 standard deviation decrease in unemployment. Correspondingly, increases in expected returns in financial markets lead to a lower unemployment rate. Particularly, a one standard deviation increase in expected returns decreases unemployment by almost 1 standard deviation. Results are in close correspondence with the economic intuition, where improvements in economic conditions are followed with lower unemployment rates. This can be also seen from figures 19, 20, and 21, where increases in realized future growth corresponds with decreases in the unemployment rate.

[Insert Figures 16, 17, 18 around here]

[Insert Figures 19, 20, 21 around here]

\section{b) Generalized Variance Decompositions}

Figure 22 displays the Diebold and Yilmaz (2012) generalized variance decompositions using the Gini Coefficient as the income inequality measure.

[Figure 22 around here]

The last bar in Figure 22 displays the contribution of the variation in income inequality explained by the other variables in the model. As can be seen, 9 percent of the variation in income inequality is contributed to the yield spread, 24.3 percent to the stock market, and 0.6 percent to unemployment. Overall, 34 percent of the variation in income inequality represented by the Gini 
coefficient is explained by these 3 variables. In addition, approximately 22 percent of the variation in expected returns comes from the yield spread and Gini coefficient. Note, 19 percent of the variation in unemployment is driven by the yield spread and almost 18 percent by expected returns in the S\&P 500.

Figure 23 displays the Diebold and Yilmaz (2012) generalized variance decompositions using the Top $1 \%$ Thiel index as the measure of income inequality.

\section{[Insert Figure 23 around here]}

As can be seen in the last bar of Figure 23, a great amount of the variation in income inequality is attributed to the other three variables in the VAR. Together the three variables explain 44 percent of the variation in income inequality with 17 percent attributed to the yield spread, 24 percent attributed to expected returns in the stock market, and 3 percent attributed to unemployment. The results again confirm that a large amount of the variation in unemployment (40 percent) is explained by the yield spread and expected returns in the stock market.

Lastly, figure 24 displays the Diebold and Yilmaz (2012) generalized variance decompositions using IPAR as the income inequality measure.

\section{[Insert Figure 24 around here]}

As can be seen from the last bar of the figure, 32 percent of the variation in top income shares is attributed to the other 3 variables in the model. 14 percent of the variation is attributed to the yield spread, 17 percent is attributed to expected returns in the stock market, and 1.7 percent is attributed to unemployment. Again, approximately 40 percent of the variation in unemployment belongs to changes in the yield spread and expected returns in stock markets. It should be noted that the estimated variance decompositions remain roughly the same even after replacing the expected returns in the stock markets with the realized expected economic growth. The only difference is 
that the relationship between the realized expected growth rate and the unemployment rate is found to be stronger. Particularly, between 30 to 40 percent of variation in unemployment comes from the realized expected economic growth rate and more than 40 percent of the variation in realized expected economic growth is contributed to changes in unemployment ${ }^{16}$.

In summary, the results document that subsequent improvements in economic conditions, as captured by increases in the yield spread, are associated with higher levels of income inequality. Note, one factor that links yield spreads with improvements in economic conditions is monetary policy. As the Federal Reserve conducts expansionary monetary policy, short term rates decrease more than long term rates leading to an upward-sloping yield curve. Given that the expansions of monetary policy are followed with growth in output, the upward sloping yield curve will correspond with subsequent economic expansion. Thus, monetary policy might be one contributing factor in linking the yield spread with income inequality. The findings suggest that expansionary monetary policy has played a role in influencing the income distribution in the U.S. This should not be seen as a surprise since wealthy households have better access to capital markets to take advantage of low interest rates and invest in equities and other entrepreneurial activities. Another important factor that can explain the positive relationship between the yield spread and income inequality is the anticipation of future inflation. As agents start to anticipate higher economic growth, they will expect higher inflation in periods of high growth. Such expectations are likely to lead to higher long term rates and an upward-sloping yield curve. Therefore, the positive association between the yield spread and income inequality indicates that subsequent increases in the inflation rate, as predicted by the steepness of the yield curve, harm households outside the top end of the income distribution. It closely corresponds with Easterly and Fischer

\footnotetext{
16 These empirical findings are not reported in the paper, but they are available upon request.
} 
(2001) and Romer and Romer (1998), where they assert that wealthy households are more likely to have better access to financial instruments to hedge their income stream against inflation.

\subsection{Conclusion}

The yield spread plays a significant role in signaling future economic conditions. It tends to be high as the economy is expected to grow and low as economic growth is expected to slow down. Thus, given the rich economic informational content of the yield spread, this paper analyzes the impact that variations on economic conditions (approximated by the yield spread) have on the distribution of income.

The results reveal that income inequality is positively related with increases in the yield spread. This suggests that economic growth predicted by the yield spread mainly benefits households at the top of the income distribution. One channel that might be driving this relationship is the significance of the yield spread in predicting changes in expected returns in financial markets. Note, most financial assets are owned by households at the top end of the income distribution, as such, the positive expected growth in financial markets predicted by the yield spread will mainly benefit the owners of these assets. Another possible channel is the distribution of resources across households. When times are expected to be good, as signaled by increases in the yield spread, it will be the wealthy households that will take advantage of this information and make investments today. Other possible channels are monetary policy and anticipated inflation rates. Overall, the findings from this paper suggest that the information revealed by variations in the yield spread are most likely being utilized by the households that have better access to capital markets. An interesting line of inquiry for future research would be to examine whether the increases and decreases in the yield spread have asymmetric effects on changes in the income distribution in the U.S. 


\subsection{Figures and Tables}

Figure 2.1 Variation of Yield Spread Overtime

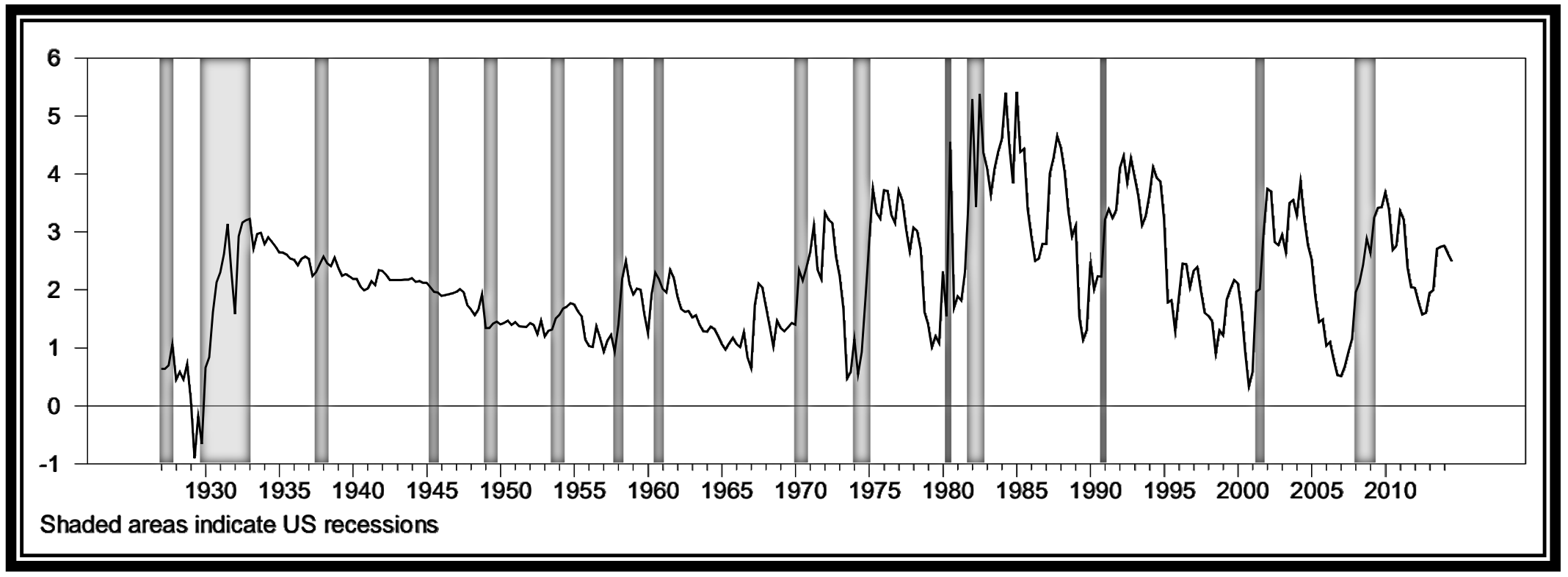


Figure 2.2 Median Value of Financial Assets

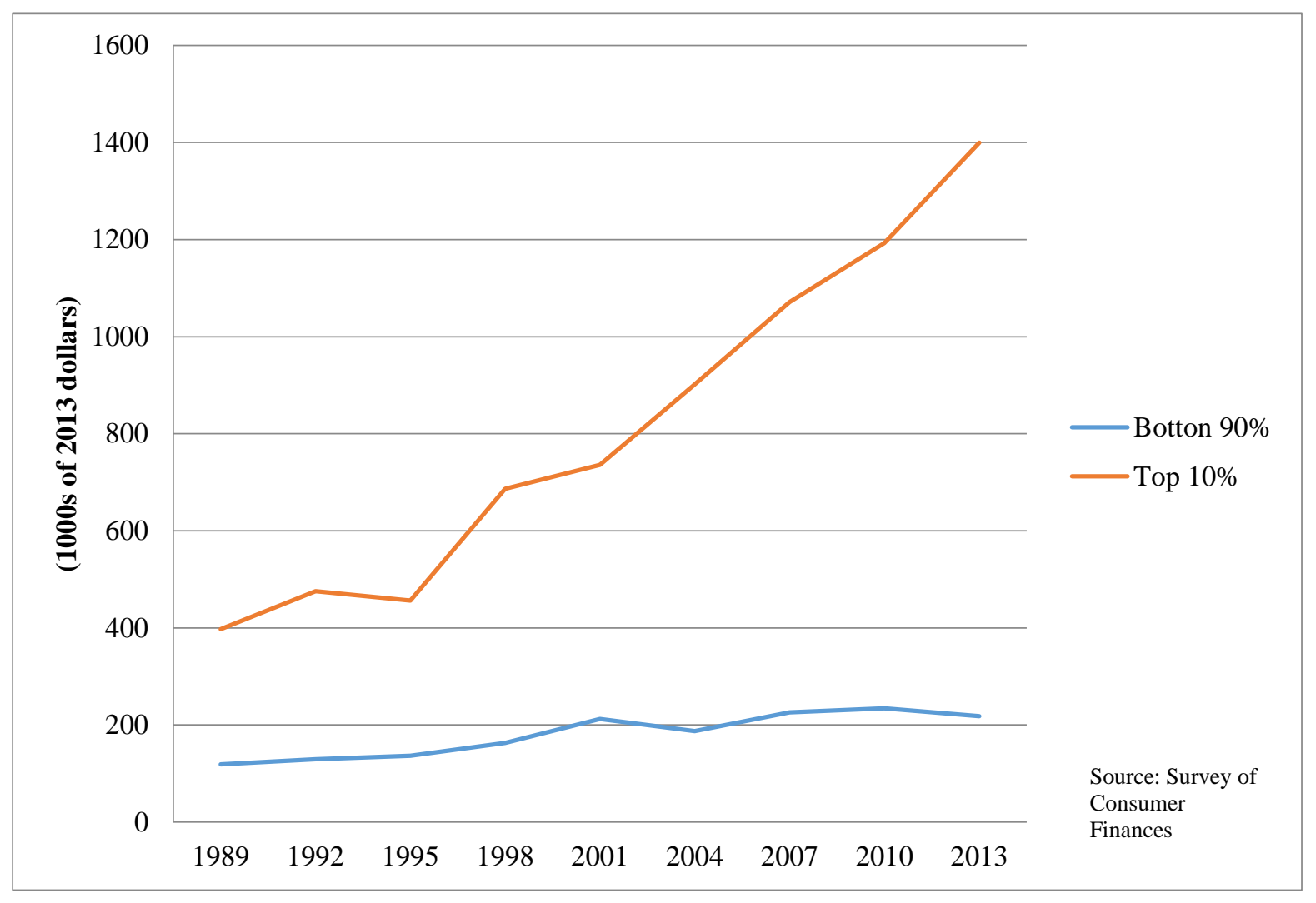


Figure 2.3 Time Variation of the three Income Inequality Measures
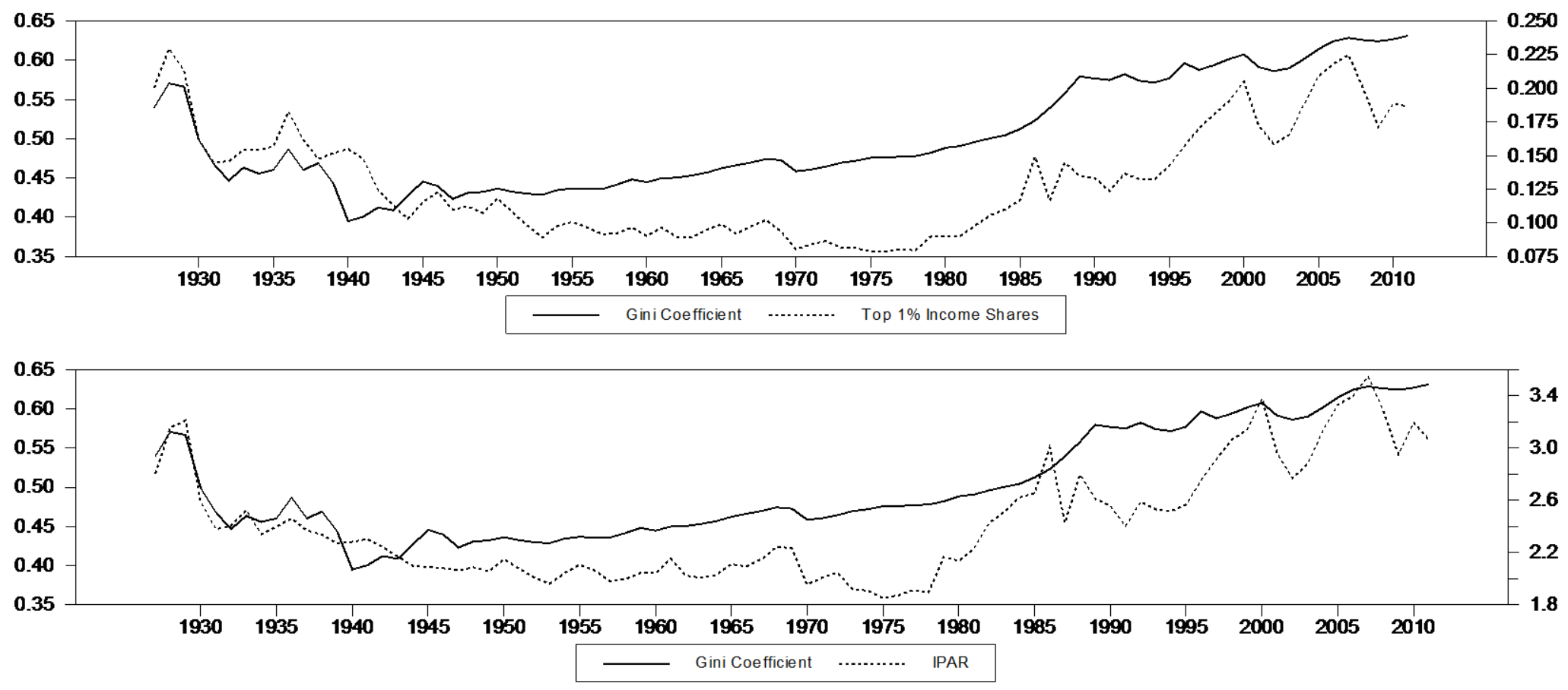
Table 2.1 Tests of predictive power of the Yield Spread for all three measures of Income Inequality

\begin{tabular}{|c|cccccc|}
\hline \hline & \multicolumn{3}{c|}{ Test Value } & \multicolumn{2}{c}{ Asymptotic critical values } \\
\hline \hline Test & \multicolumn{5}{c}{$\pi=1$} \\
& Gini Coeff. & Ipar & Top 1\% Thiel & $\mathbf{1 0 \%}$ & $\mathbf{5 \%}$ & $\mathbf{1 \%}$ \\
\hline MSF-F & -1.702 & $2.394^{* *}$ & $3.276^{* *}$ & 0.752 & 1.552 & 3.607 \\
\hline MSF-t & -0.233 & $0.717^{*}$ & $0.564^{*}$ & 0.438 & 0.767 & 1.433 \\
\hline ENC-F & $6.299^{* * *}$ & $3.667^{* * *}$ & $6.743^{* * *}$ & 0.995 & 1.601 & 3.237 \\
\hline ENC-t & $1.792^{* *}$ & $2.062^{* * *}$ & $2.148^{* * *}$ & 0.953 & 1.333 & 2.05 \\
\hline & & & & $10 \%$ & $5 \%$ & $1 \%$ \\
Test & & $\pi=0.5$ & & $\mathbf{1 0} \%$ \\
MSF-F & $3.313^{* * *}$ & $1.615^{* *}$ & $4.728^{* * *}$ & 0.804 & 1.438 & 2.992 \\
\hline MSF-t & 0.524 & 0.589 & $1.112^{* *}$ & 0.625 & 0.981 & 1.565 \\
\hline ENC-F & $5.879 * * *$ & $2.311^{* *}$ & $4.842^{* * *}$ & 0.743 & 1.206 & 2.406 \\
\hline ENC-t & $1.791^{* *}$ & $1.52^{* *}$ & $2.012^{* * *}$ & 1 & 1.371 & 2.002 \\
\hline
\end{tabular}

Note: $\pi=1$, spans in-sample period from $1927-1968$ and out-of-sample period from $1969-2011$; $\pi=0.5$, spans in-sample period from $1927-1983$ and out-sample period from $1984-2011$; 
Figure 2.4 Generalized Impulse Responses of Income Inequality Using Gini as Income Inequality Measure
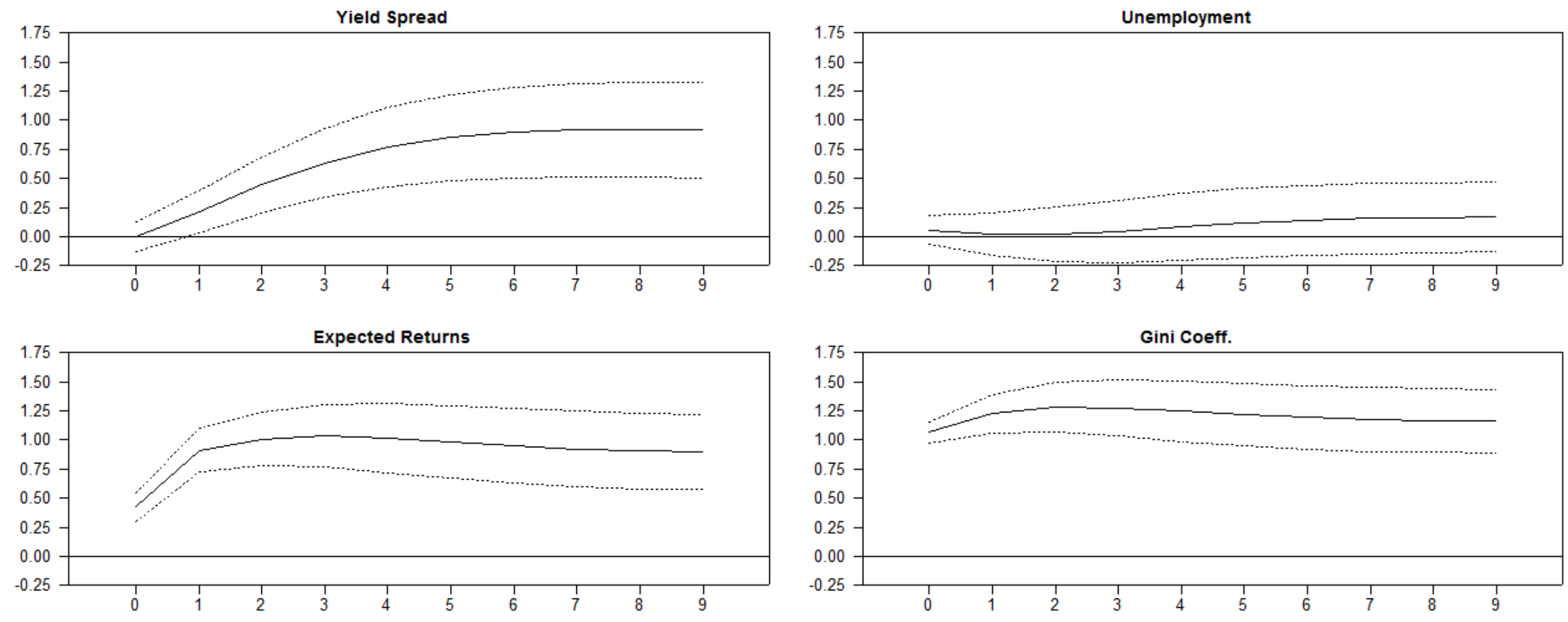

\section{Responses of Gini Coeff}


Figure 2.5 Generalized Impulse Responses of Income Inequality Using Top 1\% Thiel Index as Income Inequality Measure
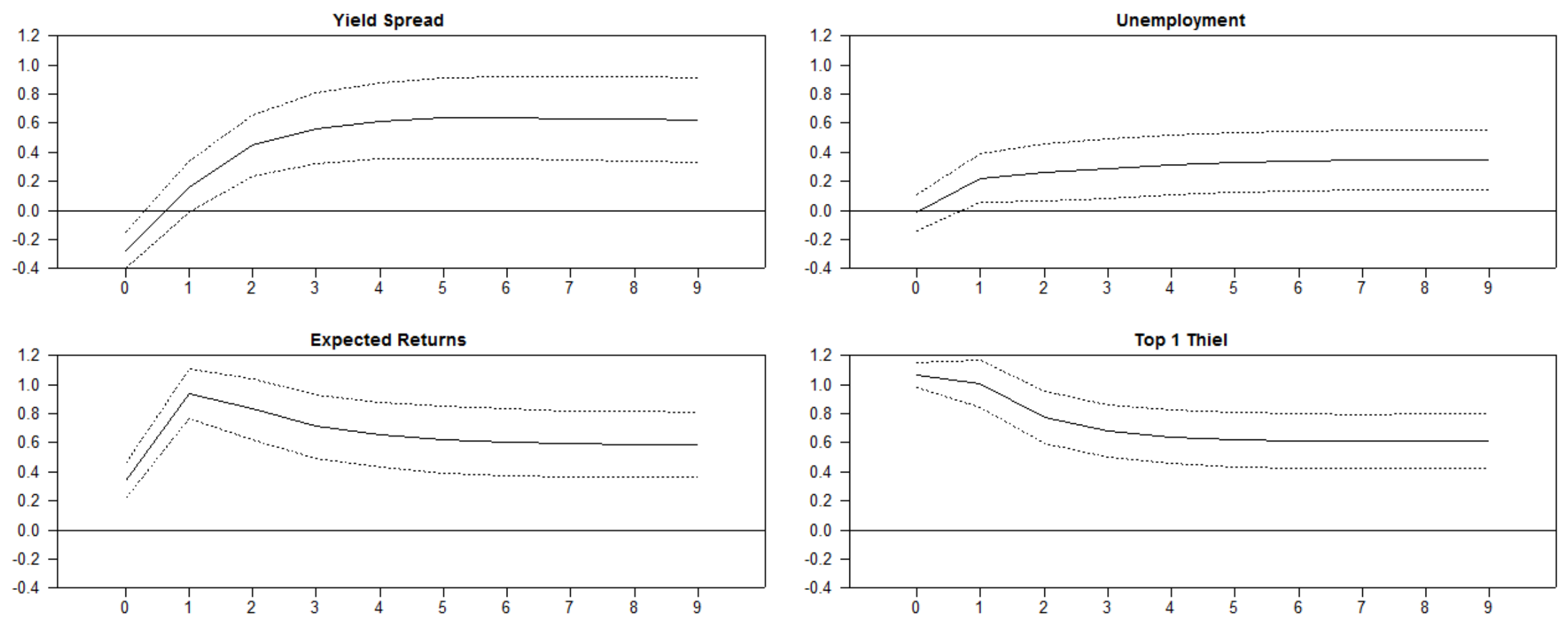

\section{Responses of Top 1 Thiel}


Figure 2.6 Generalized Impulse Responses of Income Inequality Using IPAR as Income Inequality Measure
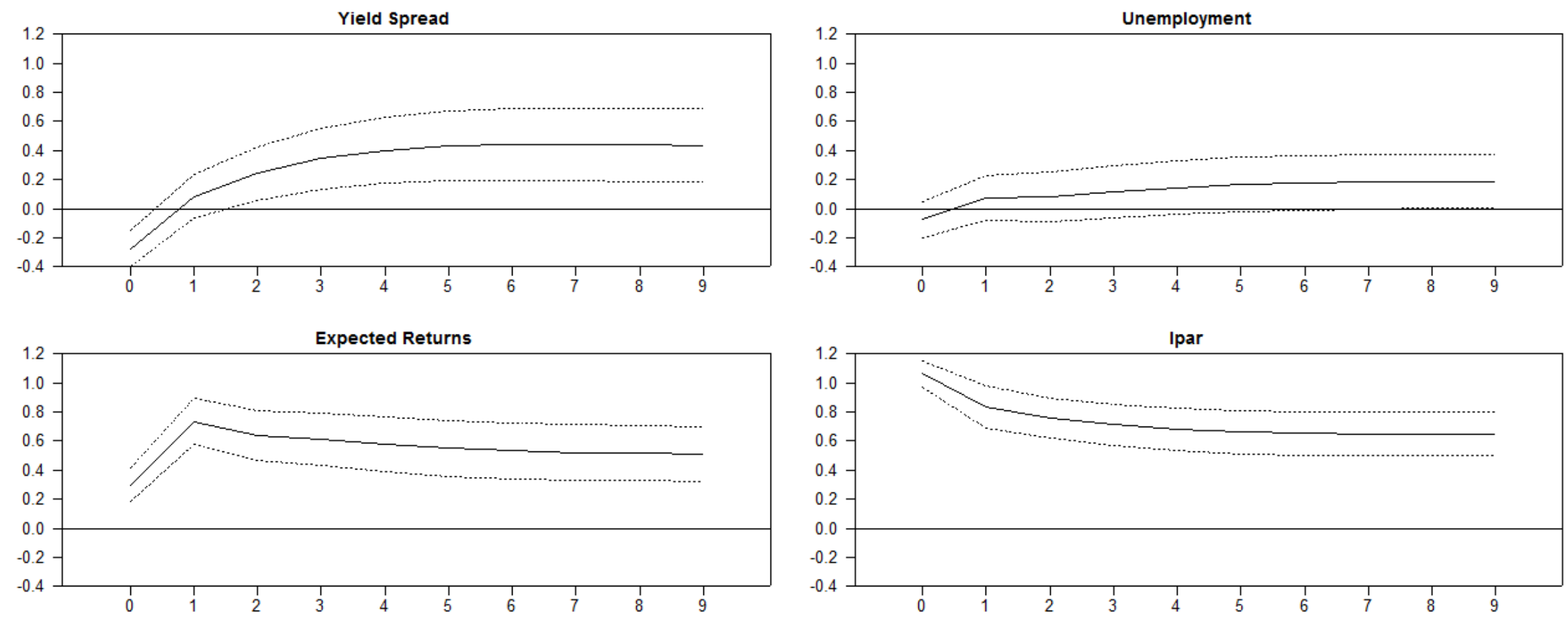

\section{Responses of Ipar}


Figure 2.7 Generalized Impulse Responses of Income Inequality Using Gini as Income Inequality Measure
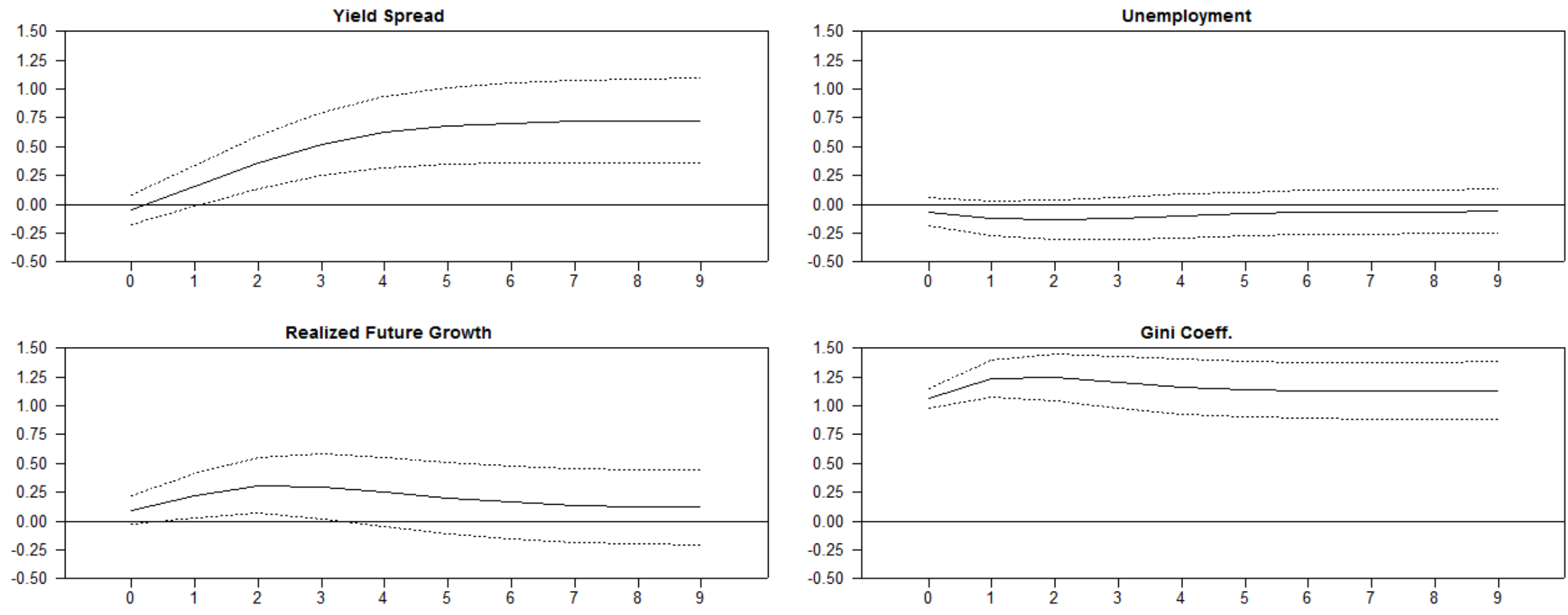

Responses of Gini Coeff. 
Figure 2.8 Generalized Impulse Responses of Income Inequality Using Top 1\% Thiel Index as Income Inequality Measure
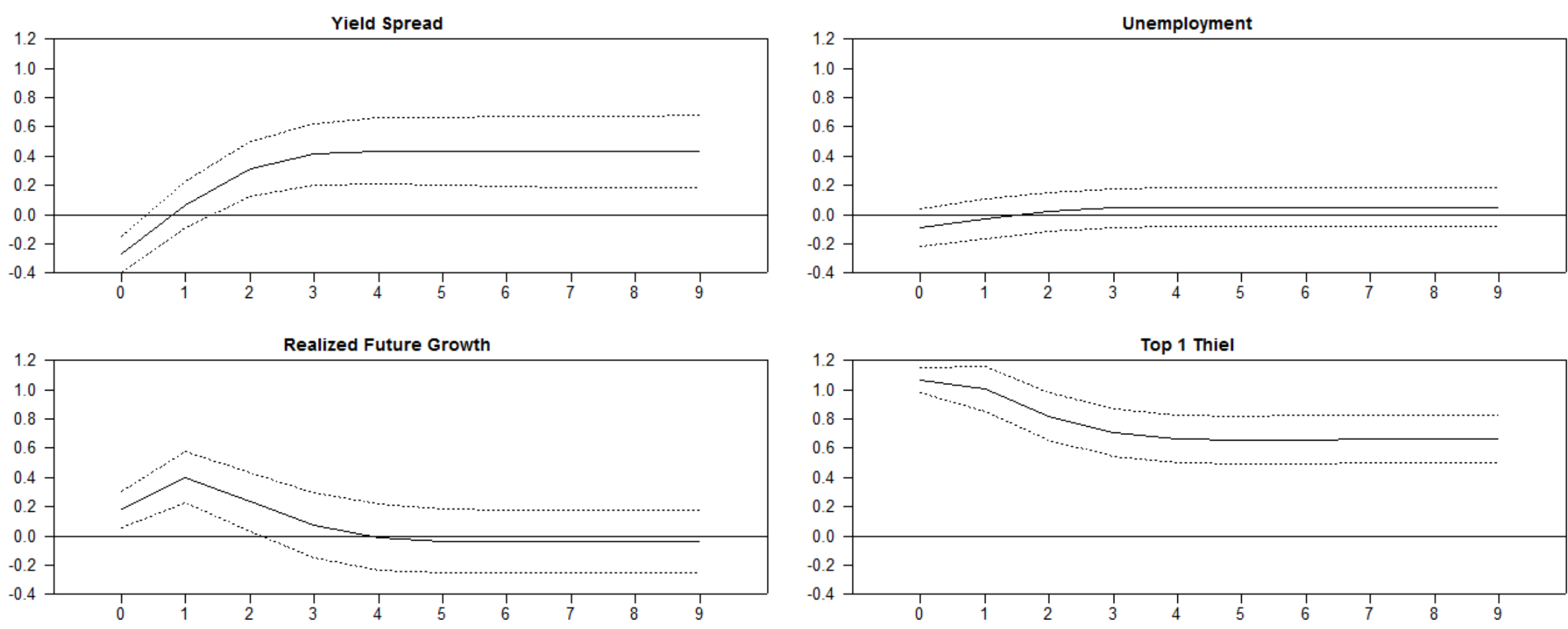

Responses of Top 1 Thiel 
Figure 2.9 Generalized Impulse Responses of Income Inequality Using IPAR as Income Inequality Measure
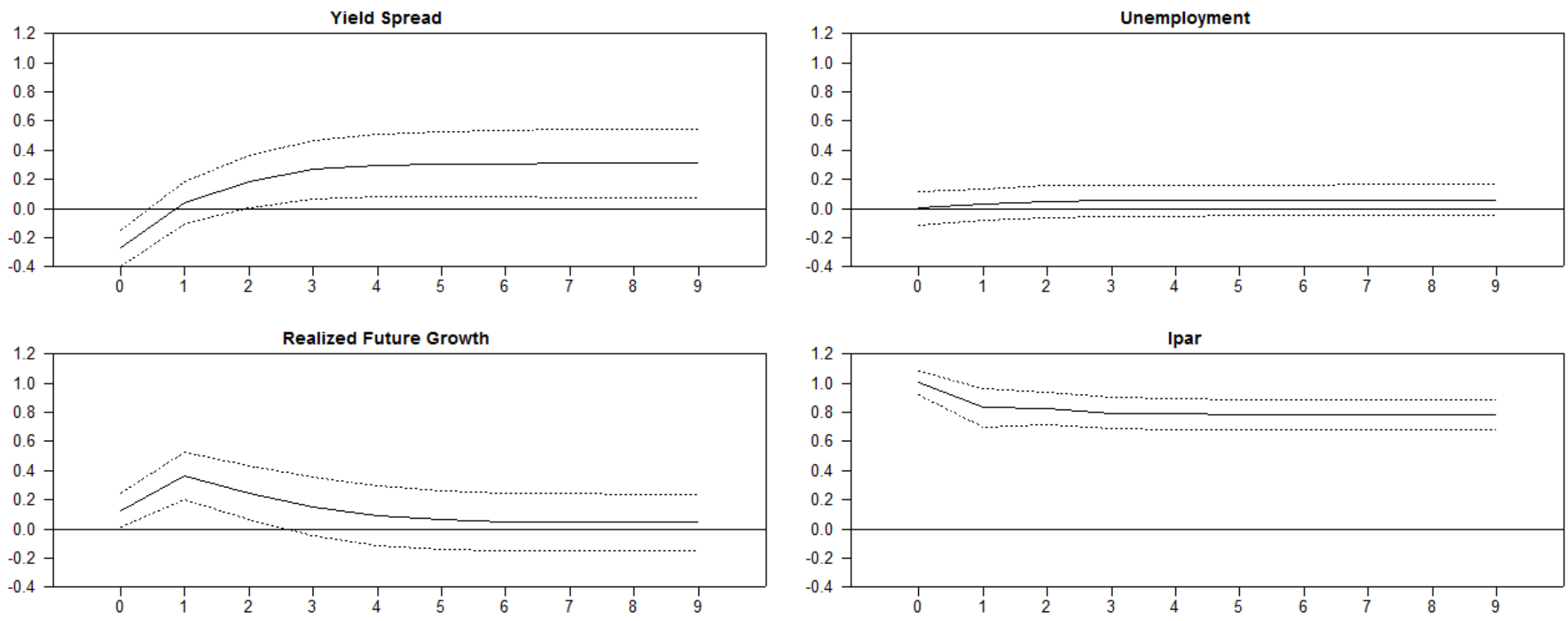

Responses of Ipar 
Figure 2.10 Generalized Impulse Responses of Expected Returns Using Gini as Income Inequality Measure
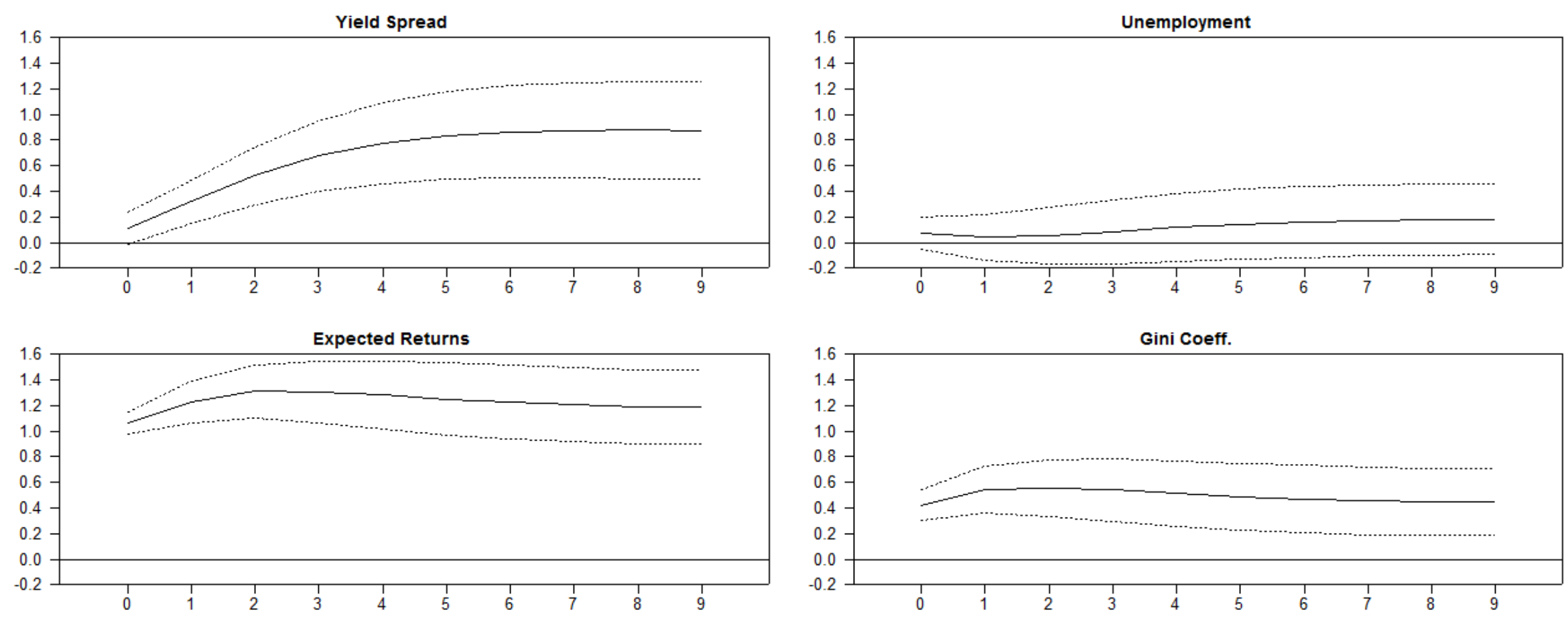

\section{Responses of Expected Returns}


Figure 2.11 Generalized Impulse Responses of Expected Returns Using Top 1\% Thiel Index as Income Inequality Measure
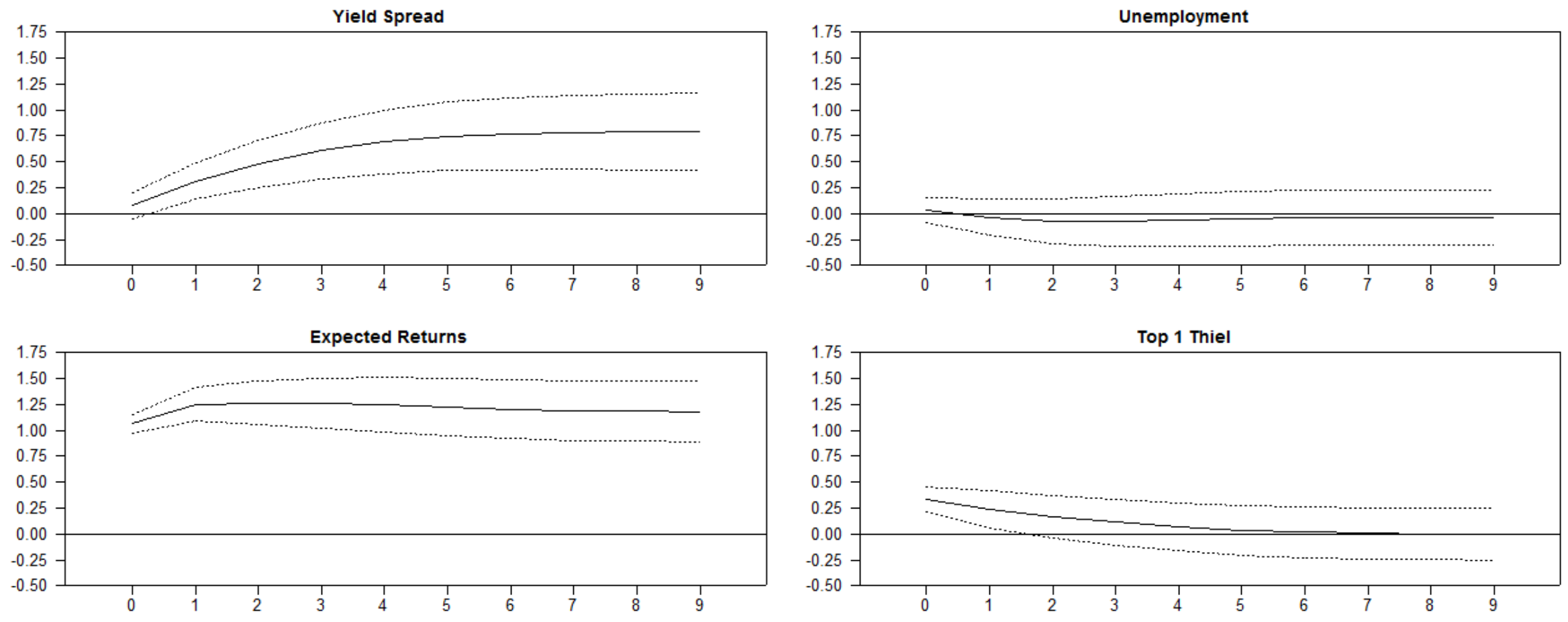

\section{Responses of Expected Returns}


Figure 2.12 Generalized Impulse Responses of Expected Returns Using IPAR as Income Inequality Measure
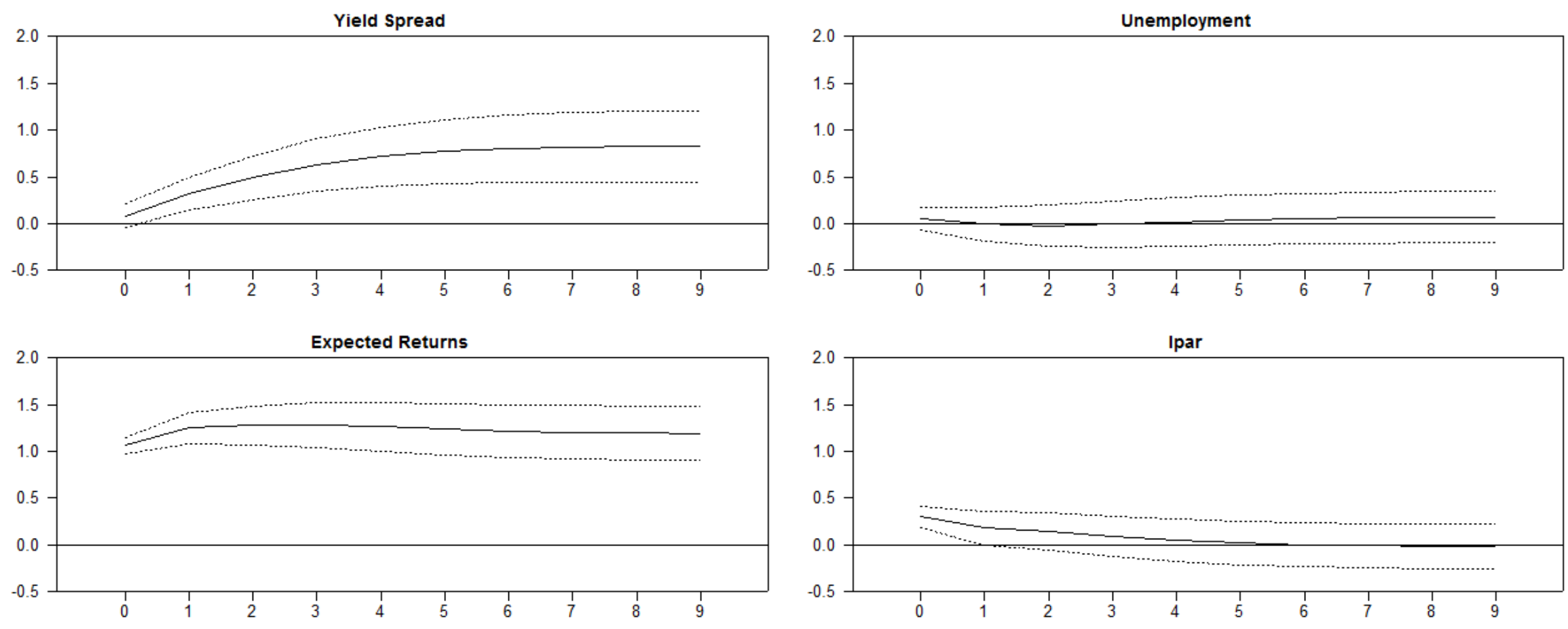

Responses of Expected Returns 
Figure 2.13 Generalized Impulse Responses of Realized Future Growth Using Gini as Income Inequality Measure
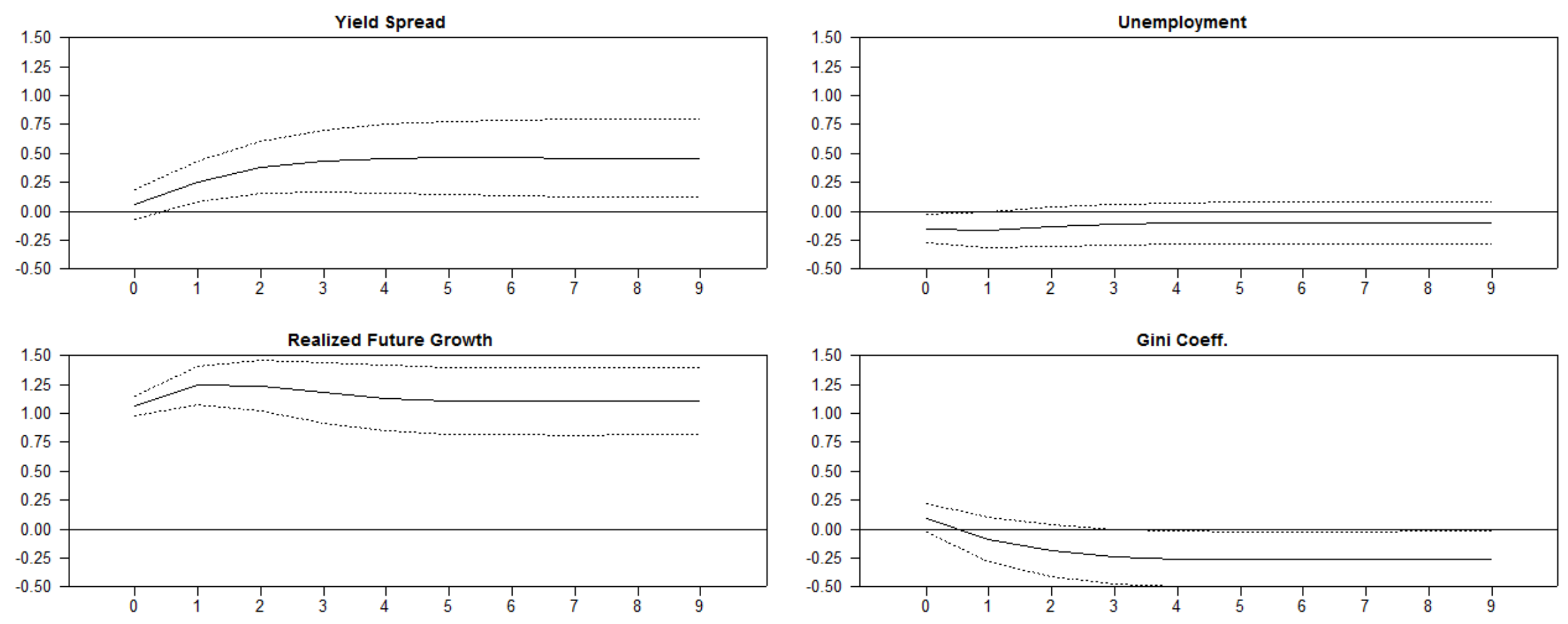

Responses of Realized Future Growth 
Figure 2.14 Generalized Impulse Responses of Realized Future Growth Using Top 1\% Thiel Index as Income Inequality Measure
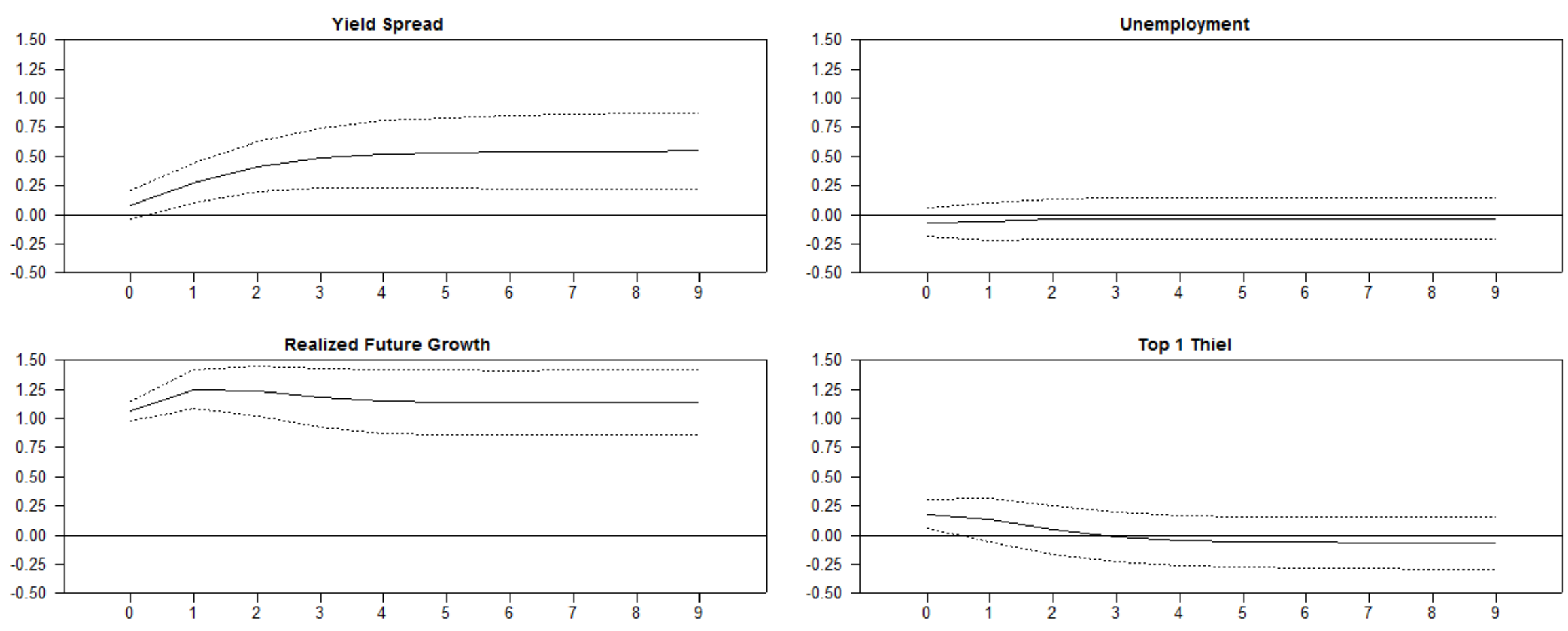

Responses of Realized Future Growth 
Figure 2.15 Generalized Impulse Responses of Realized Future Growth Using IPAR as Income Inequality Measure
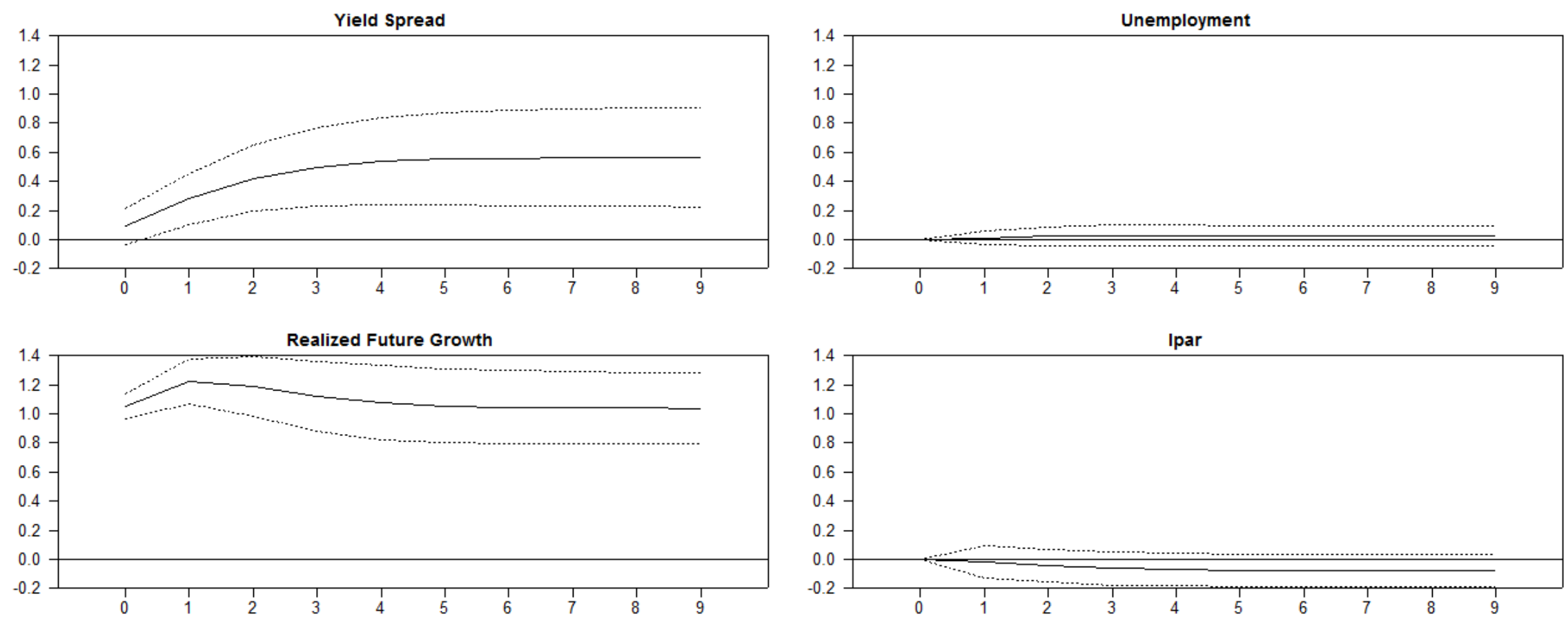

Responses of Realized Future Growth 
Figure 2.16 Generalized Impulse Responses of Unemployment Using Gini Coefficient as Income Inequality Measure
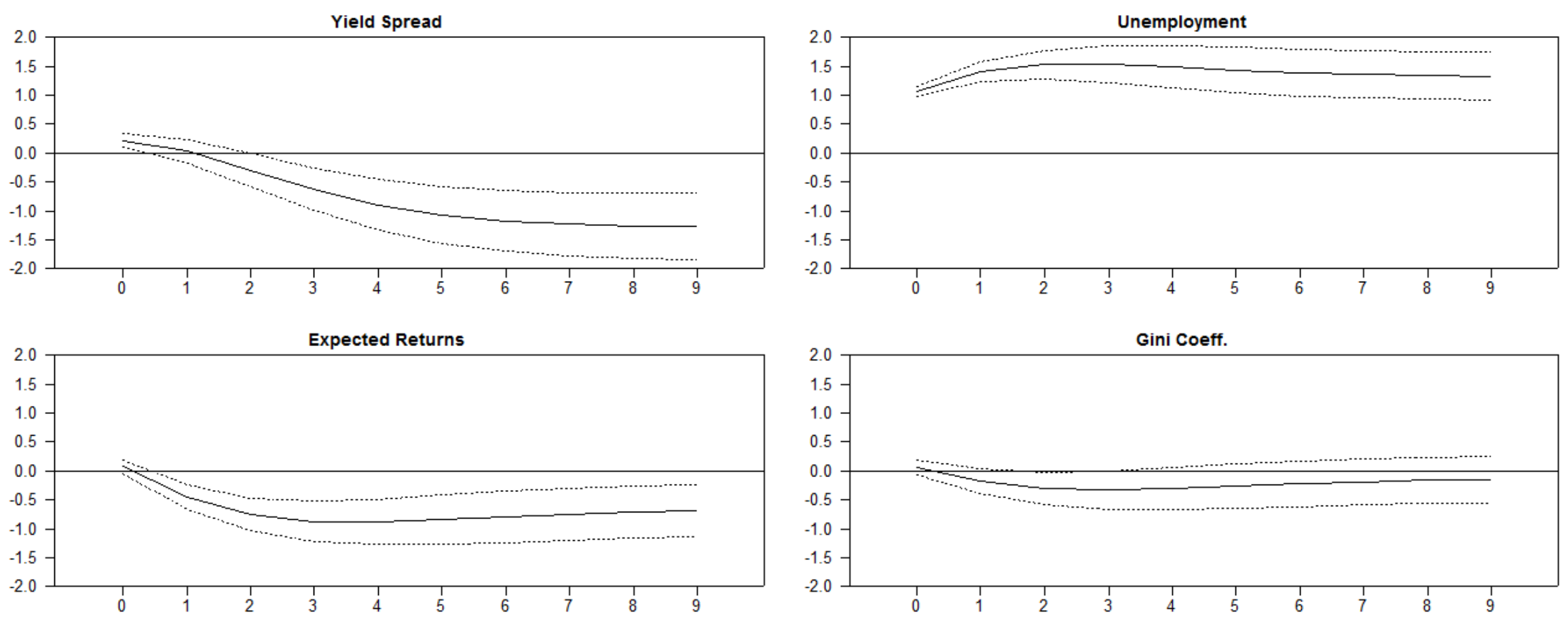

Responses of Unemployment 
Figure 2.17 Generalized Impulse Responses of Unemployment Using Top 1\% Thiel Index as Income Inequality Measure
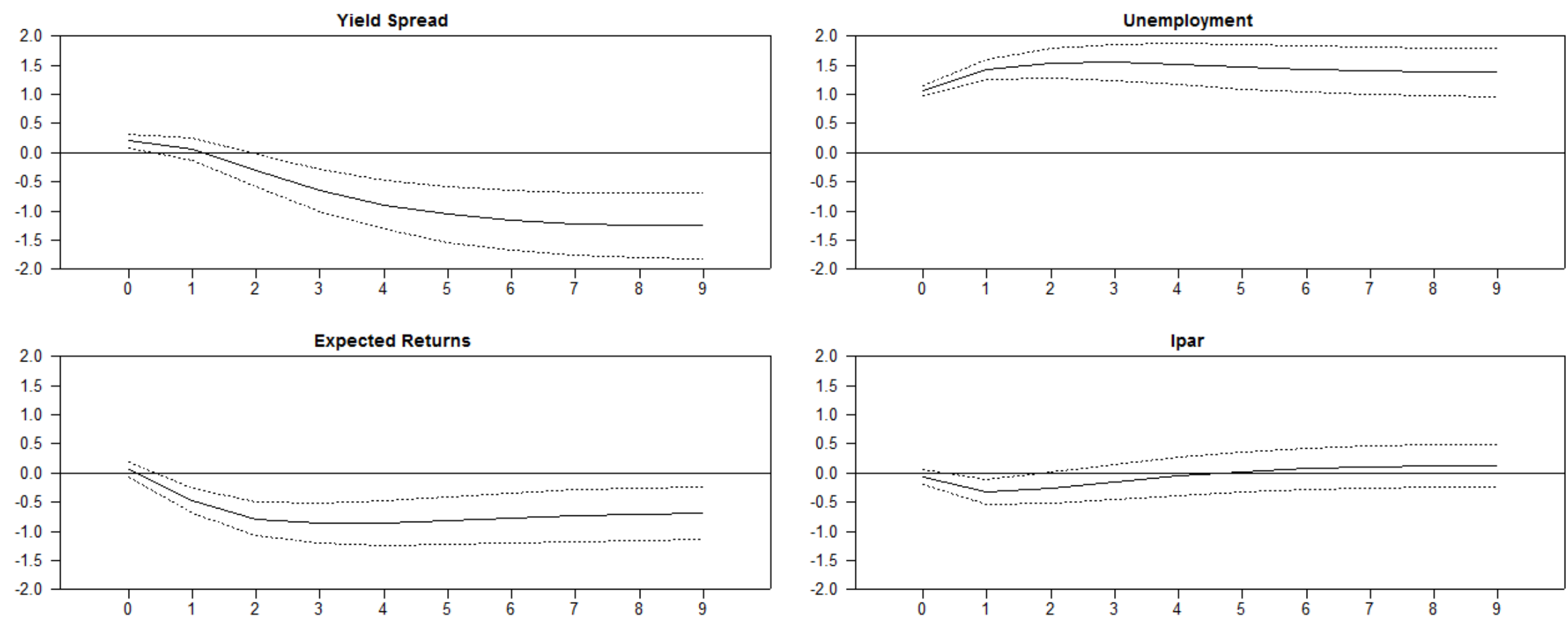

\section{Responses of Unemployment}


Figure 2.18 Generalized Impulse Responses of Unemployment Using IPAR as Income Inequality Measure
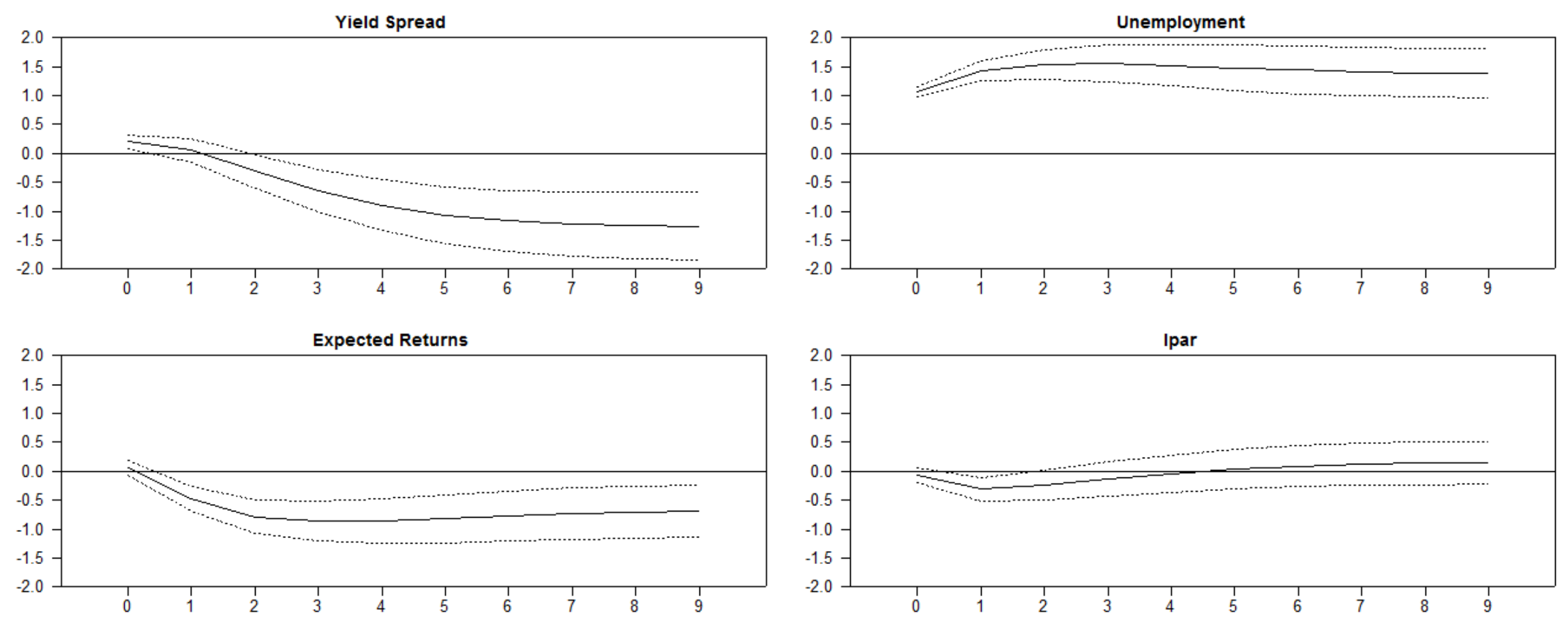

Responses of Unemployment 
Figure 2.19 Generalized Impulse Responses of Unemployment Using Gini Coefficient as Income Inequality Measure
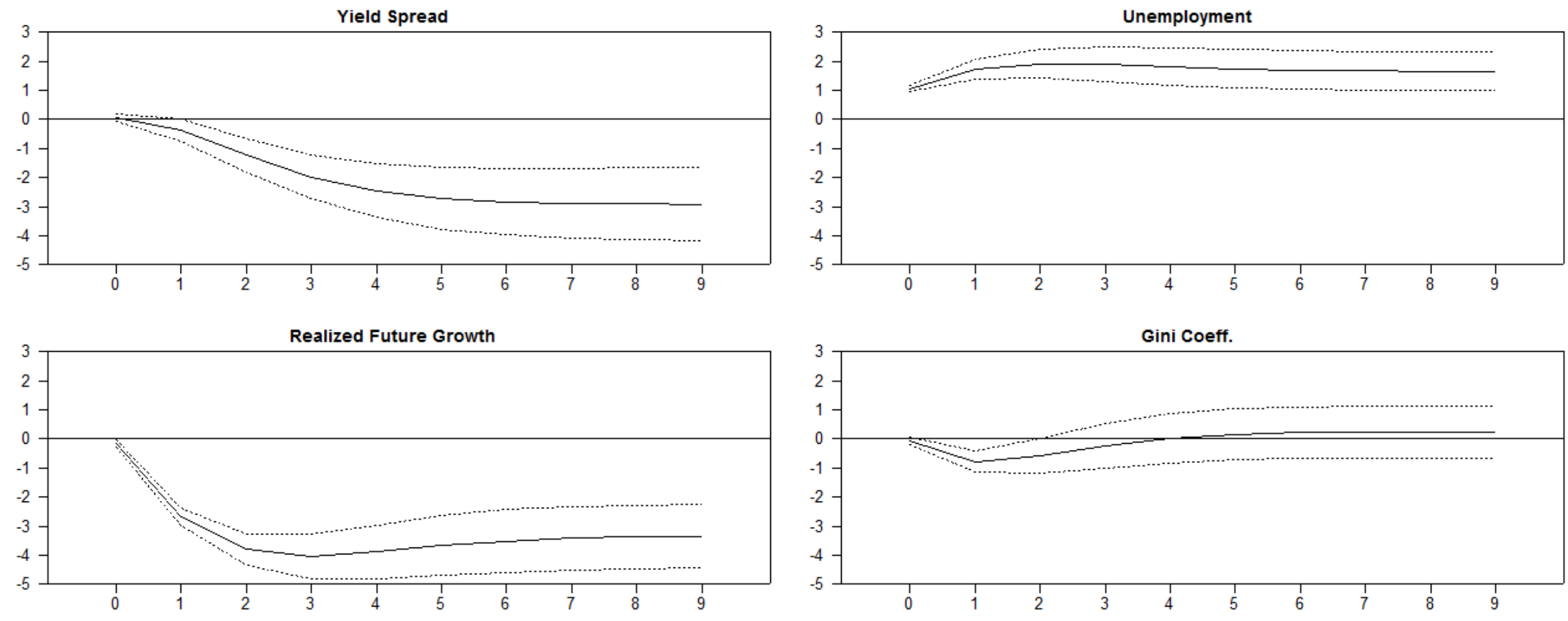

Responses of Unemployment 
Figure 2.20 Generalized Impulse Responses of Unemployment Using Top 1\% Thiel Index as Income Inequality Measure
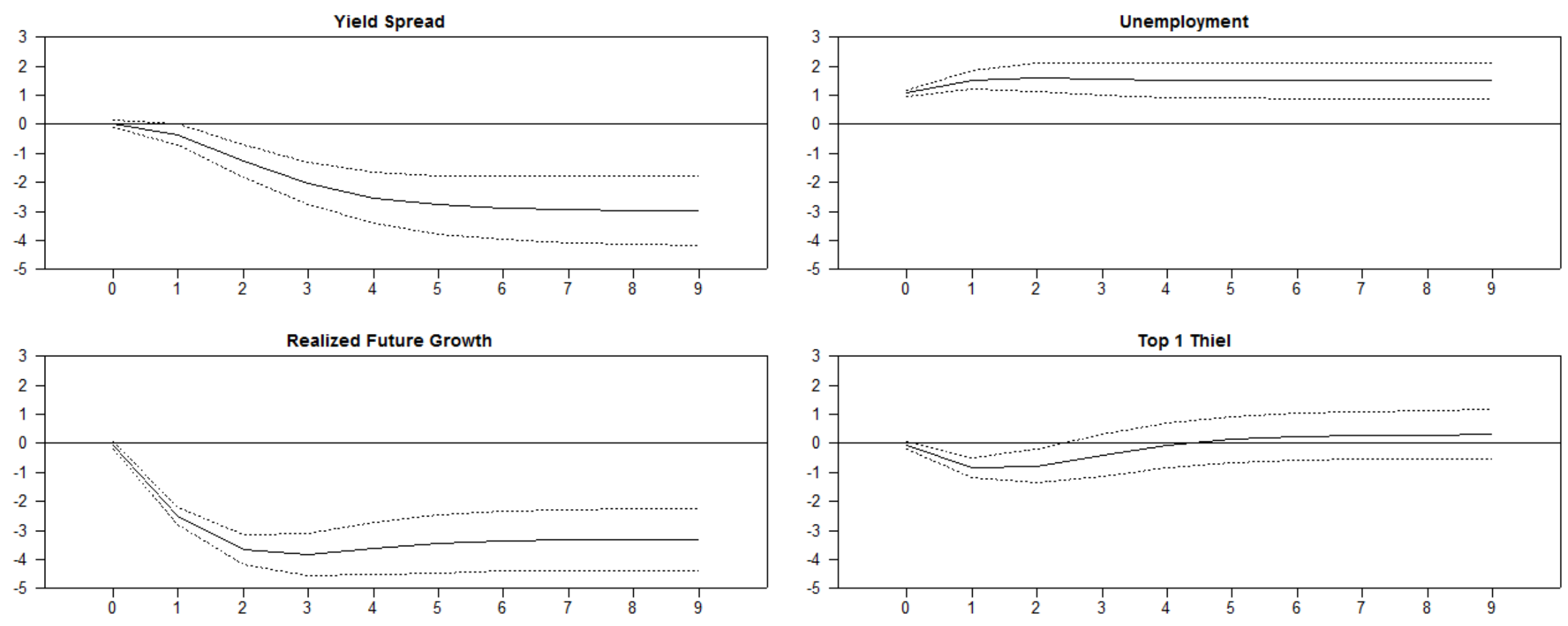

Responses of Unemployment 
Figure 2.21 Generalized Impulse Responses of Unemployment Using IPAR as Income Inequality Measure
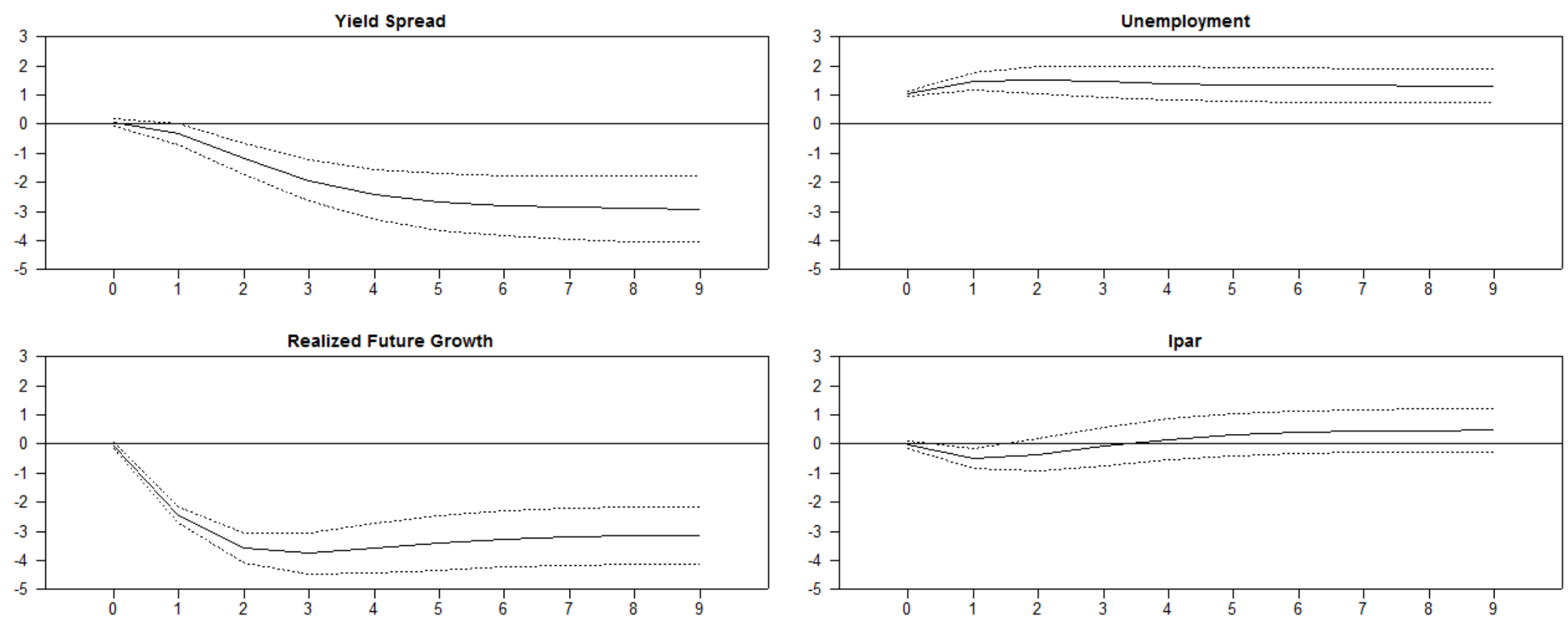

Responses of Unemployment 
Figure 2.22 Diebold and Yilmaz (2012) Variance Decompositions using Gini Coefficient as Income Inequality Measure

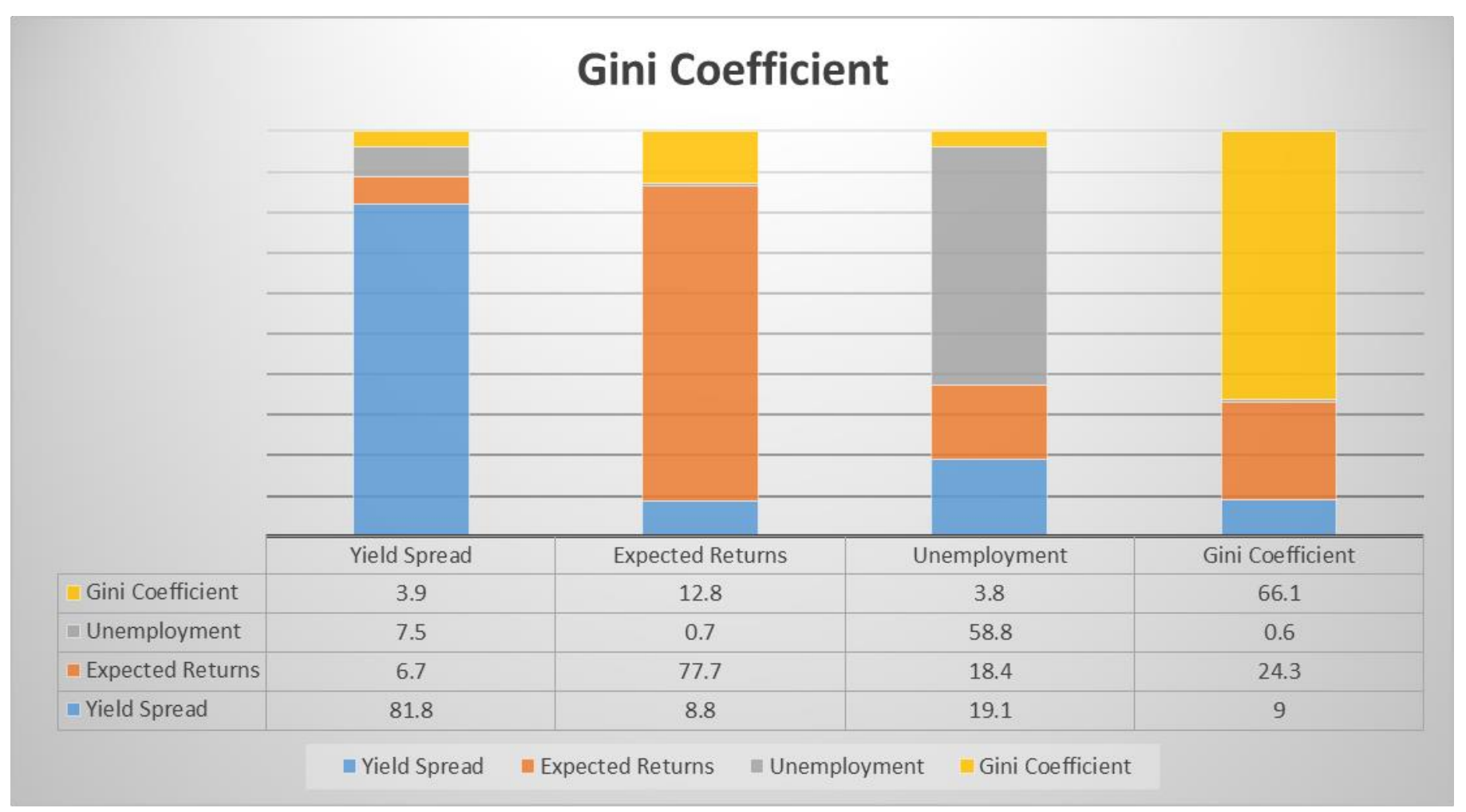


Figure 2.23 Diebold and Yilmaz (2012) Variance Decompositions using Top 1\% Thiel Index as Income Inequality Measure

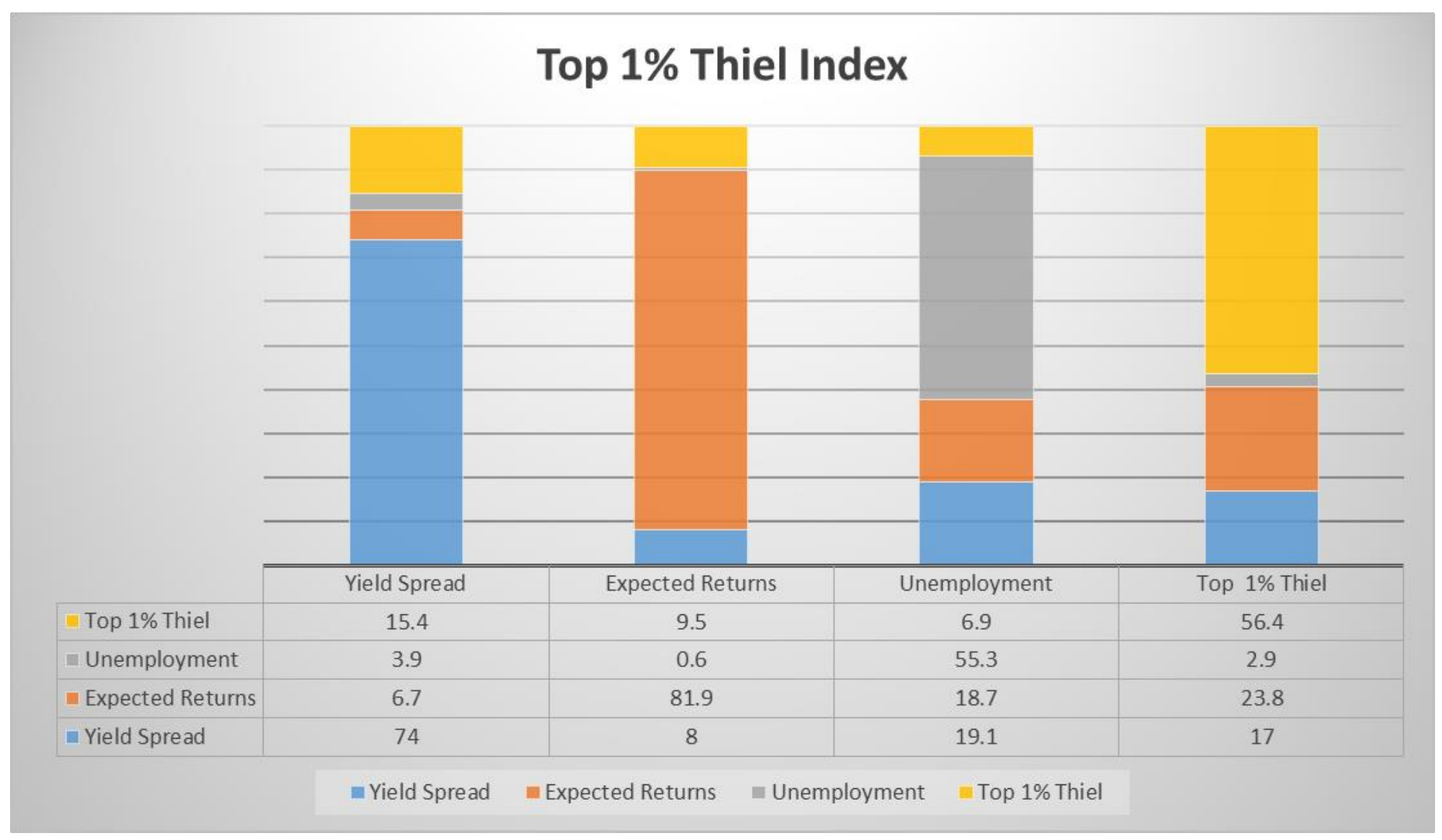


Figure 2.24 Diebold and Yilmaz (2012) Variance Decompositions using Inverted Pareto Lorenz Coefficient (IPAR) as Income Inequality Measure

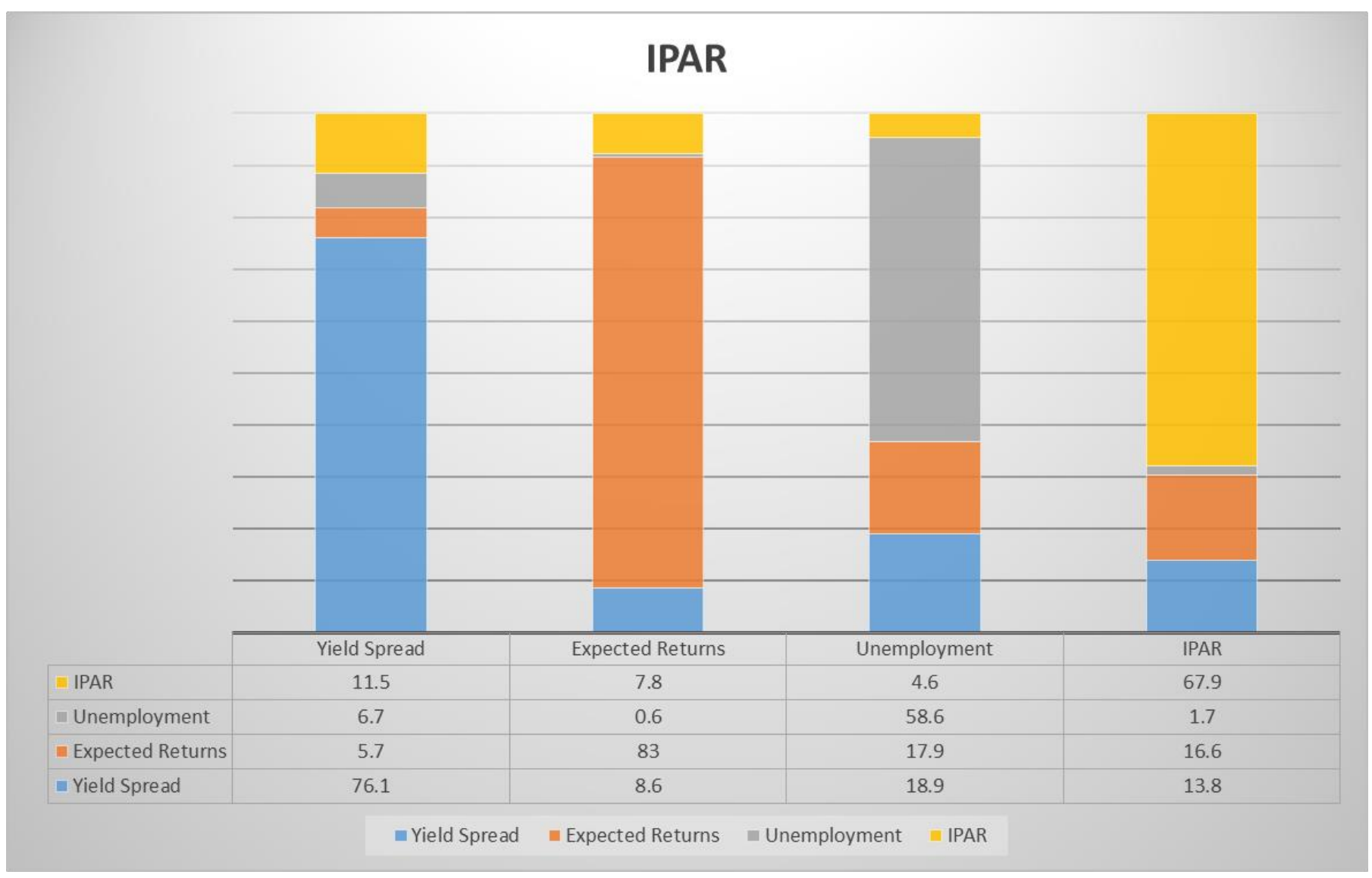




\section{ECB Monetary Policy Actions and the Economic Conditions of a Non-Euro Member: The Case of Croatia}

\subsection{Introduction}

Since the onset of the European Debt Crisis, the European Central Bank (ECB) has been providing liquidity through conventional and unconventional measures. The aim has been to stimulate real economic activity in the Eurozone (Fahr et al. (2013) and Giannone et al. (2012)). While the charter of the ECB explicitly states that the ECB governing council is only to take into account the economic conditions of the Eurozone as a whole, one criticism of recent ECB policy has been that their policy prescriptions are primarily dominated by the concerns of the largest economies in the Eurozone. As such, a growing number of smaller euro area economies have begun to question whether the benefits of joining the EMU outweigh the costs. Because adoption of the Euro requires the joining member's central bank to surrender the link between the amount of currency in circulation and the domestic economic conditions, many policy makers are doubting that the adoption of the euro is in their country's best interest. For instance, government officials of a relatively small EU member, Croatia, have stated that they will only relinquish their domestic currency when their domestic economic conditions improve.

This paper suggests that a small non EMU economy needs to be careful on highlighting costs and benefits when it comes to deciding on not adopting Euro. It needs to take into consideration the independence of its central bank on dealing with external monetary shocks, particularly with shocks from ECB monetary policy changes. As well, detecting at what level the external shocks drive the economic activities. From Figure 1, we can observe that during the period of financial crisis ECB pursued significant cuts in interest rates. In the other side, Croatian National Bank $(\mathrm{CNB})$ responded intensely by rising money market rates in order to protect exchange rate 
stability and avoid the jeopardies of self-fulfilling deprecations (Bokan 2009). As presented in the figure, the exchange rate remained stable for a while, but it came with a cost of decreases in local industrial production in double digit and disinflation, further exacerbating the impact of the last financial crisis on Croatian economy.

[Insert Figure 1 around here]

Thus, the primary purpose of this paper is to empirically test whether the ECB's monetary policy exercises any impact on domestic economic conditions of Croatia given its size, location, and future commitment to join the euro. The analysis helps us better understand how the economy of a non-EMU member responds to ECB interest rate changes if it does not fully "import" the ECB's monetary policy actions.

The CNB applies a managed floating exchange rate through market interventions in an attempt to maintain relative stability of Croatia's exchange rate. The paper examines the success of this policy in preventing spillovers from ECB monetary policy actions. The market intervention does not necessarily infer that the CNB mimics the ECB in monetary policy decisions but it implies that the CNB directly participates in the foreign exchange rate market by purchasing and selling foreign exchange to commercial banks. Nevertheless, currency interventions may be effective in managing exchange rate fluctuations, but it is not all clear that official intervention is very successful in preventing spillovers from ECB's monetary policy changes. Figure $2 \& 3$ display the scatter plot of the inflation rate in Croatia and the ECB's Monetary Policy Rate (defined as Euribor 3-Month rate and ECB interest rates for main refinancing operations). As can be seen, there appears to be a positive relationship between the ECB's Monetary Policy Rate and the inflation rate in Croatia. Therefore, the exchange rate intervention might be successful in preventing excessive exchange rate fluctuation, but this does not imply that the other economic variables, such 
as inflation, domestic money supply, and output will not respond to changes in Euribor. The analysis helps us better understand the costs and benefits of a small EU economy, Croatia, not joining the Eurozone.

\section{[Insert Figure 2\&3 around here]}

The literature about the determinants of inflation in Croatia (Botrić and Cota (2006), Vizek and Broz (2007), and Malesevic-Perovic(2009)) and for other eastern European countries (Tkalec (2012), and Benkovskis et al. (2011)) seem to not have identified that the monetary policy actions initiated by the ECB can impact prices in non-Euro economies. Several interesting facts arise from this study. ECB monetary policy changes induce significant responses in several macroeconomic variables of Croatia. An increase in ECB's policy rate induces a significant and instantaneous increase in Croatian interest rates which, in turn, are accompanied by price increases and improvement in industrial production. One possible explanation for positive response of domestic prices and industrial production to ECB's monetary disturbances is the response of the money supply in Croatia. An increase in ECB's monetary policy rate makes borrowing in local currency more attractive. As such, money supply in Croatia responds positively leading in to increases in local aggregate demand. In the empirical section, it is documented that the exchange rate is unaffected from foreign monetary shocks, whereas interest rates, prices, and production show positive responses. The findings also shows that local monetary aggregates in Croatia respond in the same direction as the foreign monetary changes. The results hold even after I control for the overall changes in the prices in the Euro Area and the European Debt Crisis.

The interest rate gap, the difference between the ECB and CNB interest rates, is found to be significant in altering the economic conditions in Croatia. This is another interesting fact that 
the paper reveals and it identifies an important channel through which ECB monetary policy actions can impact the economic variables of a small non-Euro member economy.

The policy implications of the results are clear. The aim of any central bank is to not let the inflation rate vary wildly. The goal for many advanced economies is to keep inflation at a $2 \%$ annual growth rate. A positive response of the local inflation rate to increases in the ECB's monetary policy rates and interest rate gap suggest that not giving up your own currency does not give you full effectiveness in conducting independent monetary policy. Also, targeting exchange rate stability does not appear to eliminate the responses of Croatian macroeconomic variables, particularly inflation, to ECB's monetary policy changes. Any monetary policy rule should include the ECB's interest rate modifications. Therefore, the EMU sceptics that support the idea of not adopting the Euro should take into account the level of autonomy non-EMU members have in setting their own monetary policy rule and how much they can deviate from the ECB's monetary policy path.

The rest of the paper is organized as follows. The next section describes the data and methodology. Section 3 discusses the empirical results. Section 4 concludes, highlighting the policy implications of the results.

\subsection{Data and Methodology}

\subsubsection{Data}

The sample period analyzed goes from January, 2003 to December, 2013. The variables for Croatia are obtained from the Croatian Central Bureau of Statistics and Croatian Central Bank. The Euribor 3-Month rate and the ECB interest rates for main refinancing operations are the variables that represent the policy rate for the Euro Area. They are obtained from the European Central Bank's website. Changes in Euro Area CPI is used to capture the overall changes in prices 
in the EURO zone. The data source is EUROSTAT. To control for the European debt crisis, I use 10-year Greek Government Bond Yields, obtained from the Bank of Greece. The Croatian monetary policy rate is represented by the 3-month interbank rate. Core Consumer Price Index is used to calculate the local inflation rate. Exchange rate is defined as the number of Kuna per Euro. Increases in the exchange rate should be read as depreciation of Kuna relative to Euro. Output is measured by seasonally adjusted industrial production. Stationarity tests based on Augmented Dickey Fuller test using different specification were performed an all these variables. To ensure stationarity, all variables are transformed in annualized growth rate.

\subsubsection{Methodology}

The dynamic relationship between ECB monetary policy actions and the domestic activities of Croatia is examined by estimating the following VAR:

$$
Y_{t}=\sum_{i=1}^{p} \phi_{i} Y_{t-i}+\psi w_{t}+\varepsilon_{t}, \quad t=1,2, \ldots, T
$$

Where $Y_{t}=\left[\begin{array}{llll}\Delta r_{t} & \Delta e x_{t} & \Delta p_{t} & \Delta y_{t}\end{array}\right]^{\prime}$ is a $m \times 1$ vector of jointly determined dependent variables, interest $\operatorname{rate}\left(\Delta r_{t}\right)$, exchange rate $\left(\Delta e x_{t}\right)$, inflation $\operatorname{rate}\left(\Delta p_{t}\right)$, and industrial production $\left(\Delta y_{t}\right) \cdot w_{t}=\left[\begin{array}{lll}\Delta r_{t}^{e c b} & \Delta \text { einf } & \Delta d c r i s i s\end{array}\right]^{\prime}$ is a $q \times 1$ vector of exogenous variable that contains the European Central Bank policy rate, Eurozone inflation rate, and European Debt Crisis. By treating this variable as exogenous, it is implied that this variable influences other variables in the system, but there is no feedback from other variables. $\Delta$ einf and $\Delta d$ crisis are included to control for the foreign prices and the European debt crisis. $\varepsilon \sim(0, \Sigma)$ is a vector of independent and identically distributed error terms. A dummy variable, that takes the value of 1 from October 2007 until December 2009 and zero otherwise is included in the model in order to control for any particular changes in the variables during the recent financial crisis. Then, from Eq.[1], the impulse 
responses of Croatian domestic variables from a one-unit shock in Euribor are estimated. To compute $95 \%$ confidence bands 10000 replications in a Monte Carlo simulation are generated.

The significance of foreign monetary shocks is reexamined by analyzing the linkages of domestic variables with respect to the interest rate spread $\left(i r s_{t}\right)$, which represents the difference between the Euribor 3-Month and Croatian 3-month interbank rate. It allows us to identify whether the deviation of the Croatian monetary policy rate from ECB's policy rate alters the economic conditions in Croatia. The spread can be influenced by the foreign monetary policy changes, as well as, domestic monetary policy changes. Empirically the linkages are examined by estimating the following VAR:

$$
Y_{t}=\sum_{i=1}^{p} \phi_{i} Y_{t-i}+\varepsilon_{t}, \quad t=1,2, \ldots, T
$$

Now, $Y_{t}=\left[\begin{array}{llll}\operatorname{irs}_{t} & \Delta e x_{t} & \Delta p_{t} & \Delta y_{t}\end{array}\right]^{\prime}$ is a $m \times 1$ vector of jointly determined dependent variables: the interest rate spread $\left(i r s_{t}\right)$, exchange rate $\left(\Delta e x_{t}\right)$, inflation $\left(\Delta p_{t}\right)$, and industrial

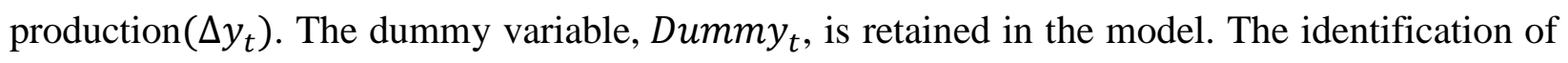
orthogonalized shocks is done through a standard Choleski-decomposition. The ordering of the variables, $\left[\operatorname{irs}_{t} \quad \Delta e x_{t} \quad \Delta p_{t} \quad \Delta y_{t}\right]$, implies that a shock on interest rate spread $\left(\right.$ irs $\left._{t}\right)$ influences each of the dependent variables contemporaneously, while a shock in output $\left(\Delta y_{t}\right)$ affects only itself contemporaneously. Thus, variables lower in the order respond contemporaneously to changes in variables that are higher in the order. The rationale for this ordering is based on the following considerations. irs $_{t}$ is placed first because part of the spread is influenced from ECB's monetary policy decisions that do not depend on the economic movements in Croatia. $\Delta e x_{t}$ is placed second upon the assumption that exchange rate will respond quickly to changes in the 
interest rate spread. Then, $\Delta p_{t}$ and $\Delta y_{t}$ are placed last in the ordering under the assumption that changes in foreign monetary shocks and exchange rate feed into changes in domestic prices and output. Reversing the ordering of $\Delta p_{t}$ and $\Delta y_{t}$ does not alter the results. Again, $95 \%$ confidence bands are estimated using 10000 replications in a Monte Carlo simulation.

\subsection{Results}

Impulse Response Functions

Figure 3 displays the impulse response functions of domestic variables in Croatia from estimating Model [1]. The lag length of the VAR was selected using AIC criteria, which resulted in two lags. For ease of exposition, the impulse responses are standardized.

\section{[Insert Figure 4 around here]}

From Figure 4, it can be seen that ECB monetary policy changes play an important role in the dynamics of economic variables in Croatia. A one unit rise in Euribor significantly and simultaneously increases Croatian interest rates by approximately 0.2 units. The response decreases down to a 0.10 unit over the 11 months period. The reaction of CNB in the same direction as ECB's monetary policy changes should be seen as an attempt of CNB to eliminate movements in exchange rates. Thus, the response of exchange rates to an ECB monetary policy change is statistically insignificant. The findings clarify the puzzle of Pterevski et al (2015), where they find that a positive Euribor shock leads to a temporary decline in the Croatian money market rate.

In addition, the results suggest that prices and output in Croatia respond positively to increases in Euribor. A one unit shock to the Euribor has a contemporaneous statistically significant positive impact on the inflation rate in Croatia which increases by approximately 0.5 units. The response remains positive but continuously decreases down to 0.2 units eleven months after the shock. Likewise, a one unit positive shock to the Euribor leads to a 0.3 units increase in output. The response dissipates over time and becomes statistically insignificant after six months. 
The findings should not be taken as a surprise. Note, as ECB increases the monetary policy rate, CNB responses in the same direction, but the magnitude of the response is much lower. As such, borrowing in the domestic currency becomes more attractive, resulting in positive responses of prices and output. .

\section{[Insert Figure 5 around here]}

One way to verify the relevance of this explanation is to examine the behavior of monetary aggregates in Croatia. Figure 5 provides evidence that monetary aggregates (changes in M1) respond positively to positive changes in Euribor. Particularly, per unit increase in Euribor, local money supply increases by 0.2 units. As before, we observe positive responses in local prices and output. Presented results remain intact even after both changes in domestic money supply and interest rates are included in the model, see Figure 6.

\section{[Insert Figure 6 around here]}

As a robustness test, ECB interest rates for main refinancing operations is used to define the ECB monetary policy rate. From Figures $7 \& 8$ it can be seen that that prices and output in Croatia respond positively to increases in ECB interest rates for main refinancing operations. CNB responds in the same direction as ECB's monetary policy changes. As before, the magnitude of the response is lower. Empirical findings might be taken as a surprise, but a similar transmission mechanism is documented in Canova (2005) for Latin American countries. He shows that contractionary US monetary shocks are turned into good output news and increase in consumer prices in Latin America.

Moreover, the interest rate spread might be an important channel through which foreign monetary policy changes might impact economic conditions in Croatia. Increases in the spread imply that CNB is not fully incorporating the ECB's monetary policy changes, making it more 
attractive to borrow in local currency relative to foreign currency (euro). Thus, as the spread rises, we should observe positive changes in monetary aggregates, as well, positive responses in local prices and output. Figures 9 to 16 display the impulse responses from estimating Model [2]. The shocks are one standard deviation Choleski factor, whereas the responses are in the units of the dependent variables.

[Insert Figure 9 around here]

Figure 9 displays impulse responses of the domestic inflation rate. Note, a one standard deviation positive shock to the interest rate spread increases the inflation rate by approximately 0.5 units. As expected, a shock to the exchange rate shows statistically no significant impact on driving changes in local prices. A positive shock in output is associated with positive responses in inflation. A one standard deviation increase in output leads to an approximately 0.25 units increase in the inflation rate. It accords with supply side theory in suggesting that inflation is a positive function of output.

\section{[Insert Figure 10 around here]}

Beside output, none of the other variables show any statistical relevance in influencing exchange rate. Figure 10 shows that per one standard deviation increase in output the exchange rate decreases by 0.25 units. The response becomes statistically insignificant after seven months. The findings suggest that improvements in output contribute in making the domestic currency stronger in the short run. Interestingly, the response of exchange rate toward its own shock is not long lasting, confirming that CNB targets exchange rate stability.

[Insert Figure 11 around here]

Figure 11 shows impulse responses of local output. A one standard deviation positive shock to the interest rate spread leads to 0.2 units increase in output. The response starts to decapitate after one 
month and becomes insignificant after four months. Findings again confirm the positive association between output and inflation. A one standard deviation positive shock to the inflation rate is associated with a 0.2 units in output. Results reveal an interesting link between output and exchange rate. It shows that local currency depreciation leads to decreases in output. This is no surprise since currency depreciation of a small economy corresponds with capital outflows followed by economic downturns.

\section{[Insert Figure 12 around here]}

Figure 12 displays the impulse responses of the interest rate spread. Note, the responses of the interest rate spread to its own shocks starts to dissipate immediately after one month and becomes statistically insignificant after ten months. It suggest that the CNB "imports", to some degree, the monetary policy actions of the ECB. Exchange rates show statistically no significant impact in driving the spread. In the other hand, a positive one standard deviation increase in local prices correspond with decreases in the spread. It can be as a result of CNB increasing the domestic interest rates to keep inflation under the control. Interestingly, increases in domestic output lead to increase in spread. The response becomes statistically insignificant after five months.

Again, increases in the spread should be seen as CNB not raising the rates at the same magnitude as the ECB's monetary policy changes. As such, increases in the spread suggest that it is becoming cheaper to borrow in local currency relative to the foreign currency (euro). If these channels hold, we should expect positive responses of monetary aggregates to increases in the spread.

The model 2 is re-estimated with exchange rate $\left(\Delta e x_{t}\right)$ being replaced with money growth $\left(\Delta m_{t}\right)$. The aim is to identify the response of local money growth to changes in the interest rate spread. 
[Insert Figure 13 around here]

From Figure 13, it can be seen that a one standard deviation increase in spread leads to 0.5 units increases in the domestic money supply. The significance prevails across the 11 months period. Interestingly, as it is shown in Figure 14, there is no feedback from growth rate in domestic money supply to interest rate spread.

[Insert Figure 14 around here]

In close correspondence with the economic theory, we can see from Figures $15 \& 16$ that domestic output and prices respond positively to increases in domestic money supply.

[Insert Figures $15 \& 16$ around here]

\subsection{Conclusion}

Current economic crisis in southern Europe, mainly Greece, has led many policy makers to question the benefits of joining EMU. Their argument is that if Greece would have had its own currency, it could have accommodate the monetary policy to its economic conditions. However, this paper argues that the benefits of not adopting Euro are not that large because ECB's monetary policy actions matter for a small non-EMU country. Analyzing the response of economic variables in Croatia, a non-EMU member that operates under a managed floating exchange rate, it is found that domestic rates, prices, and output respond positively to increases in the ECB's interest rates. Additionally, a positive interest rate spread is found to have a significant impact on the Croatian economy. Therefore, the official currency intervention might smooth out the disturbances in the exchange market, but the findings identify significant responses in Croatian economy due to the monetary policy changes of the European Central Bank. 


\subsection{Figures and Tables}

Figure 3.1 Growth Rates of Key Variables

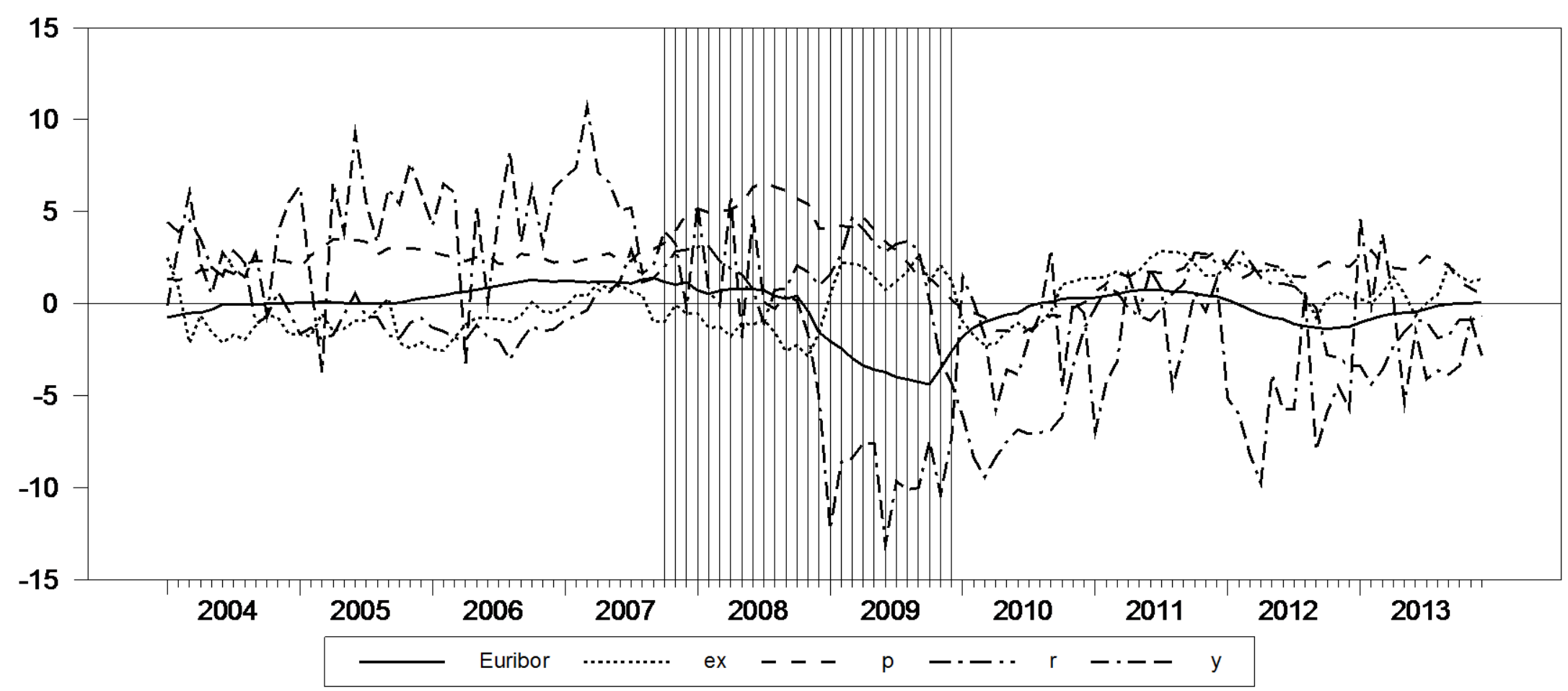

Note: The Graph shows the growth rate of ECB policy rate (Euribor), Exchange Rate (ex), domestic inflation (p), the growth rate in domestic monetary policy $(\mathrm{r})$, and the growth rate in industrial production $(\mathrm{y})$. Grids indicate the dummy variable used to control for the financial crisis, $2008-2009$. 
Figure 3.2 Correlation between ECB policy rate (Euribor) and Croatian Inflation Rate

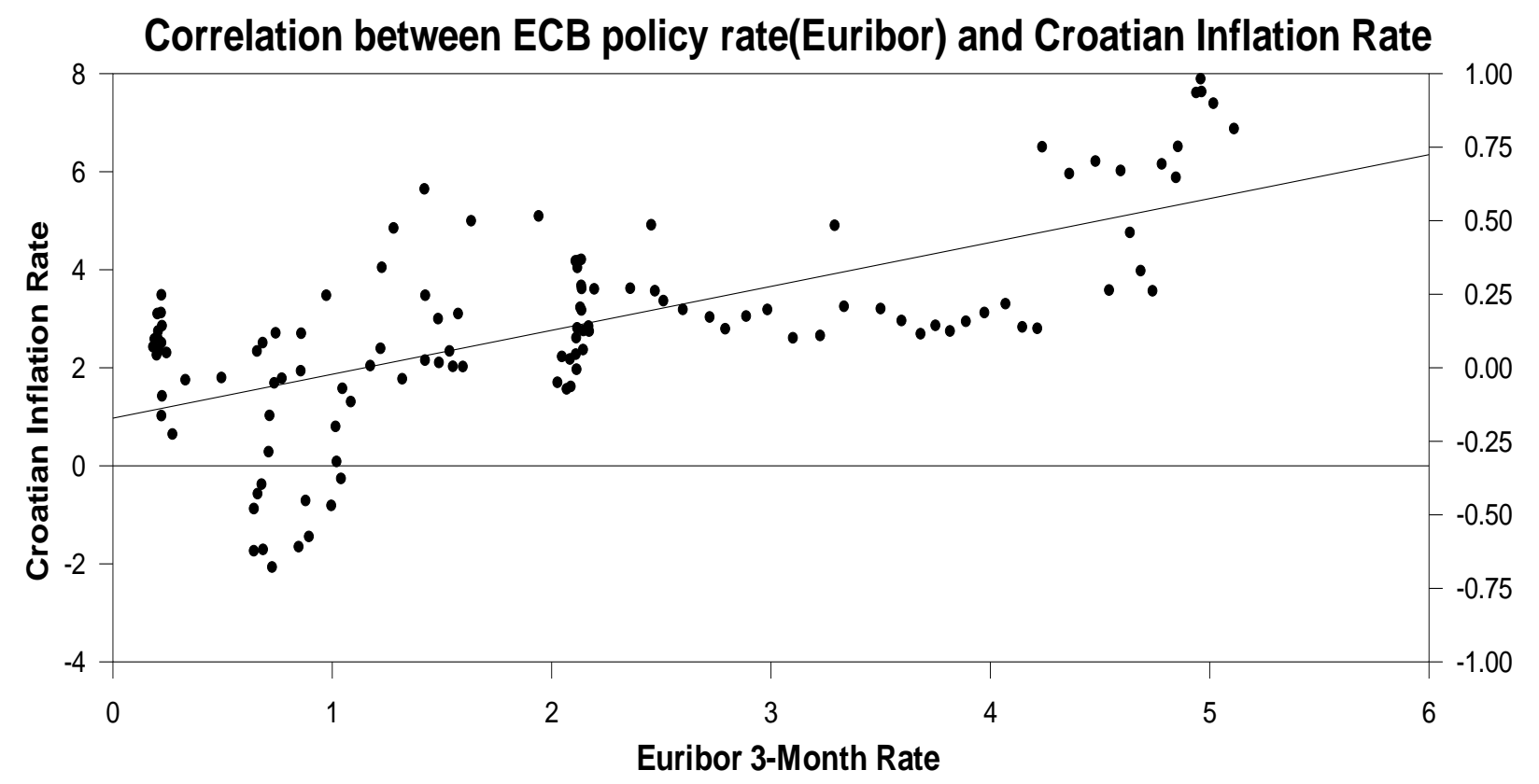

Figure 3.3 Correlation between ECB MRO rate and Croatian Inflation Rate

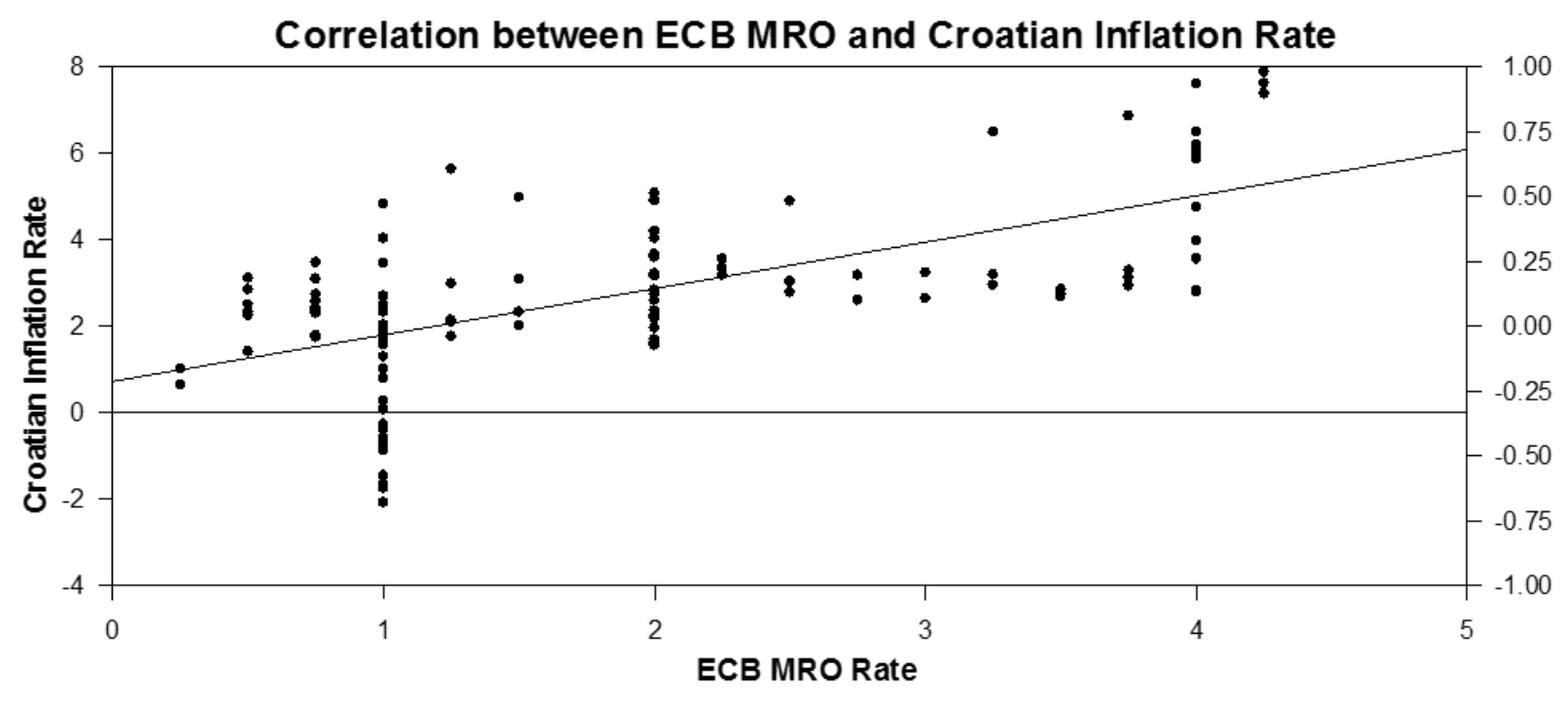


Figure 3.4 Impulse Responses of Croatian Domestic Variables to 1 unit positive shock to Euribor
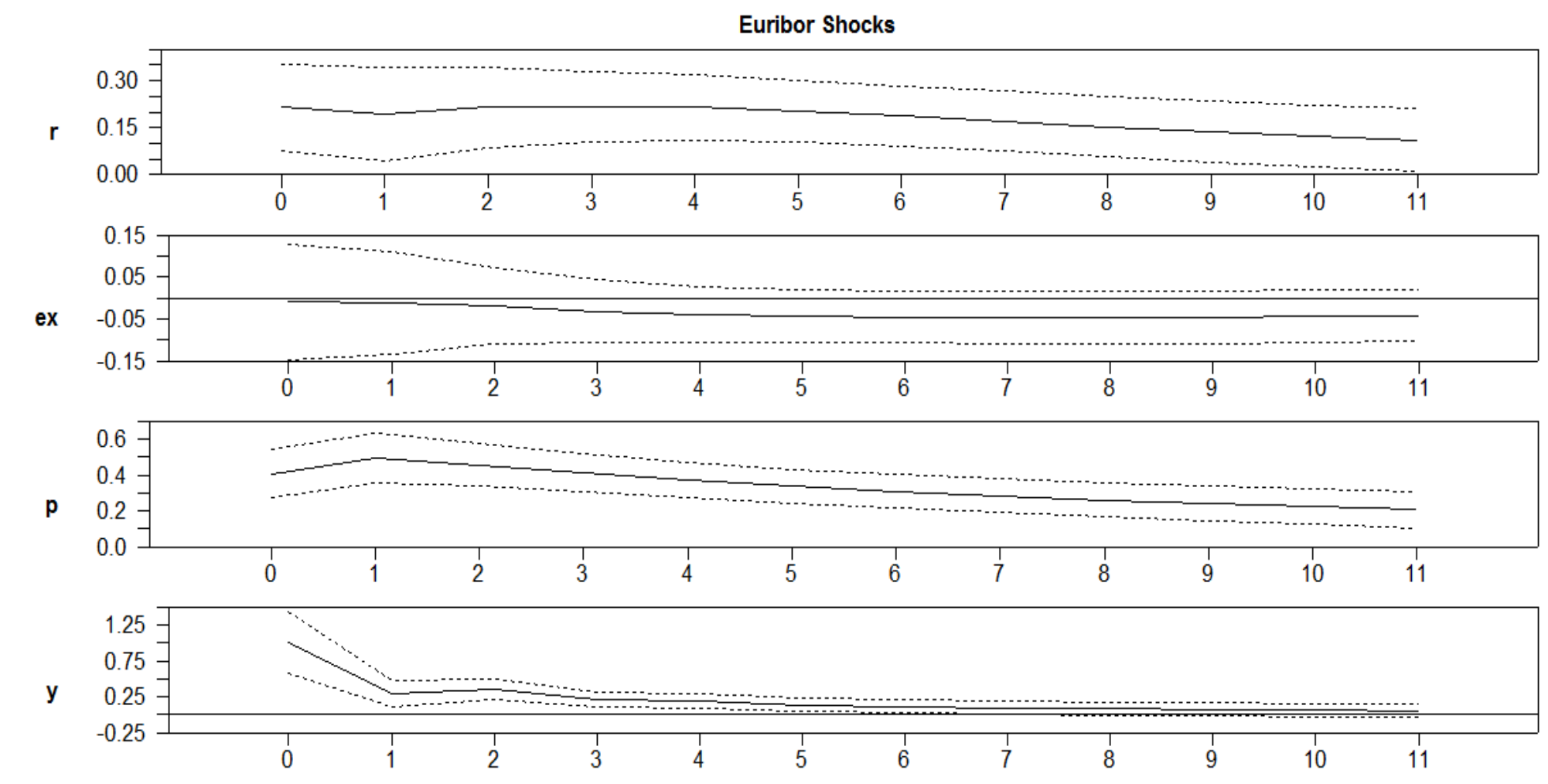
Figure 3.5 Impulse Responses of Croatian Domestic Variables to 1 unit positive shock to Euribor
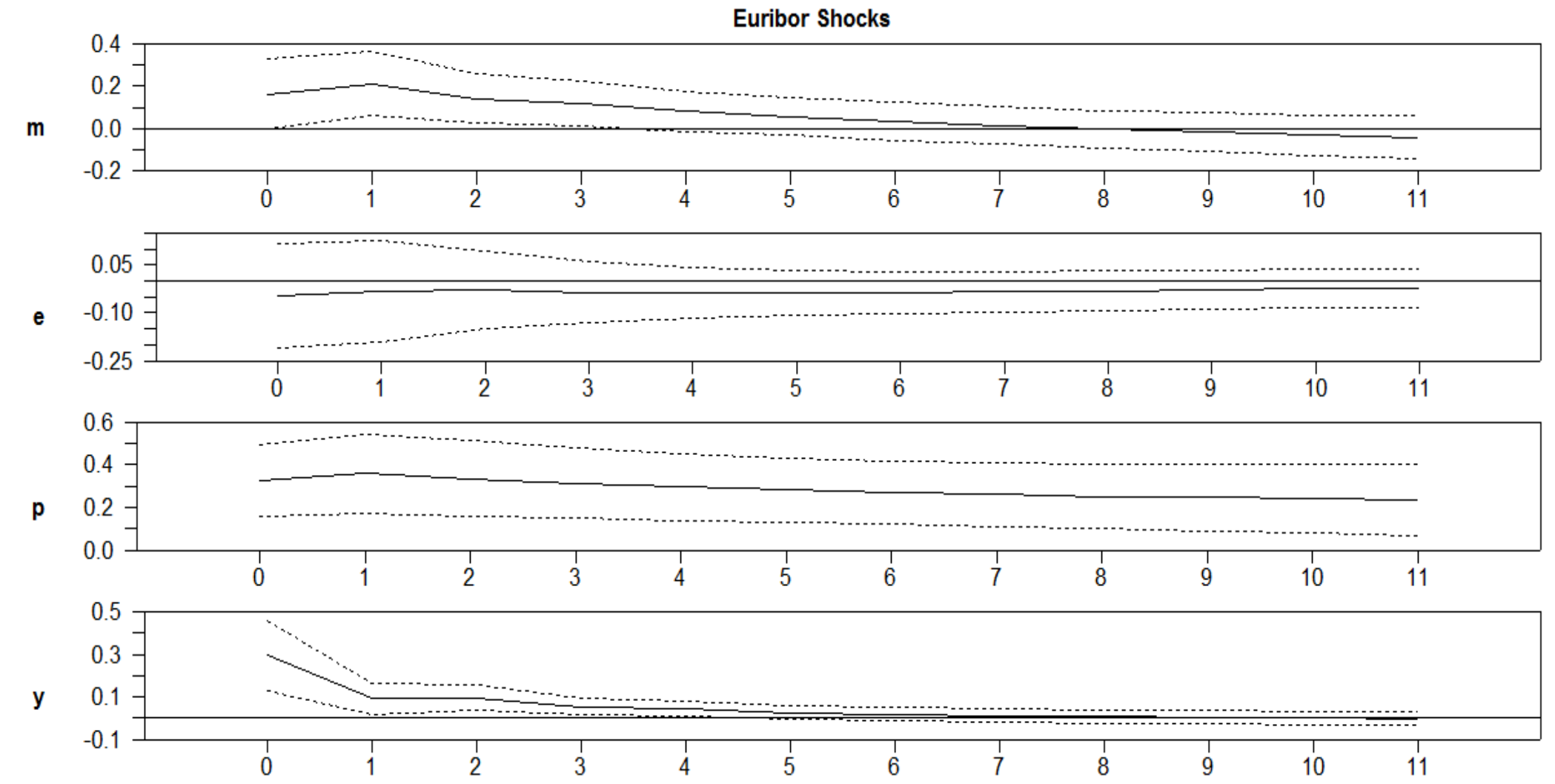
Figure 3.6 Impulse Responses of Croatian Domestic Variables to 1 unit positive shock to Euribor
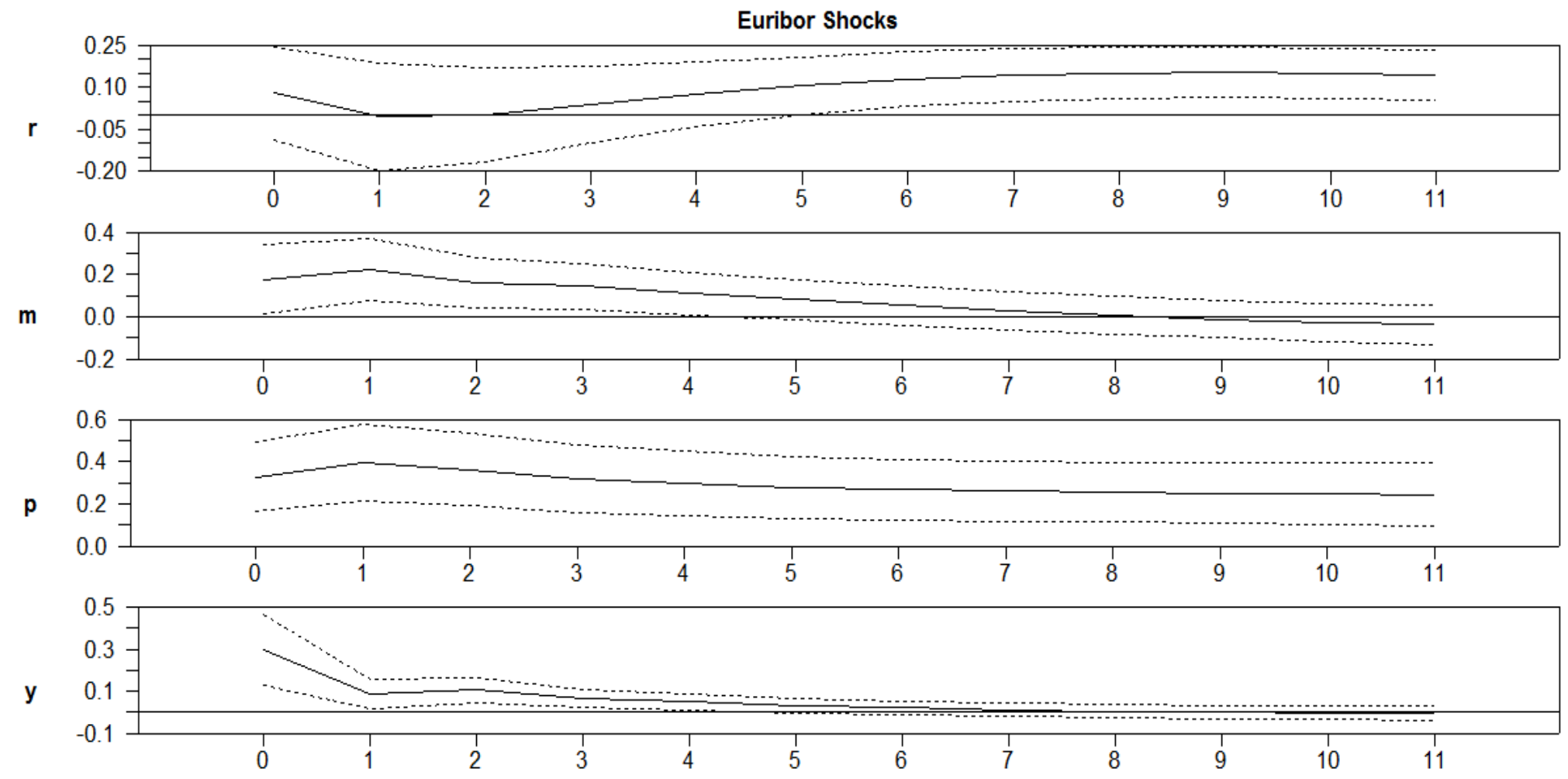
Figure 3.7 Impulse Responses of Croatian Domestic Variables to 1 unit positive shock to MRO
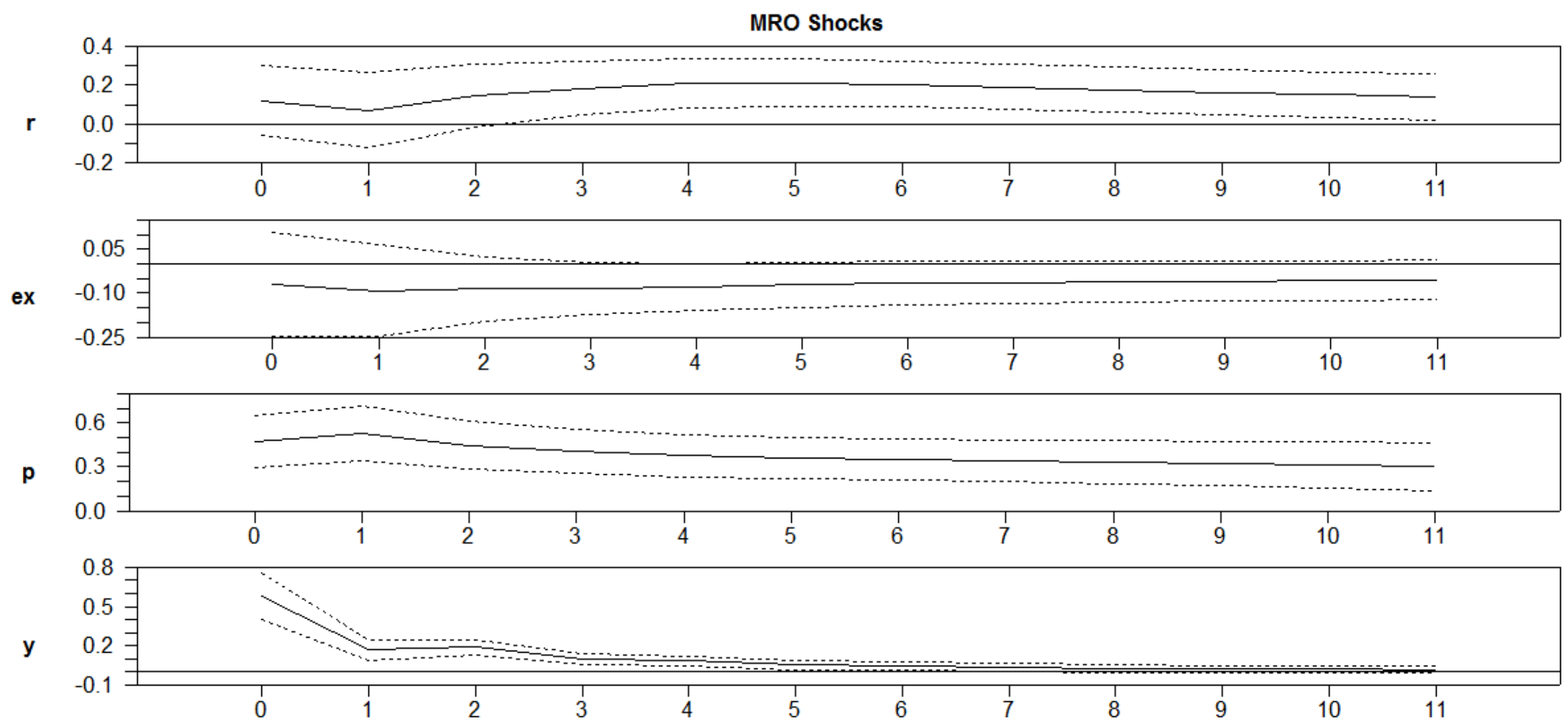
Figure 3.8 Impulse Responses of Croatian Domestic Variables to 1 unit positive shock to MRO

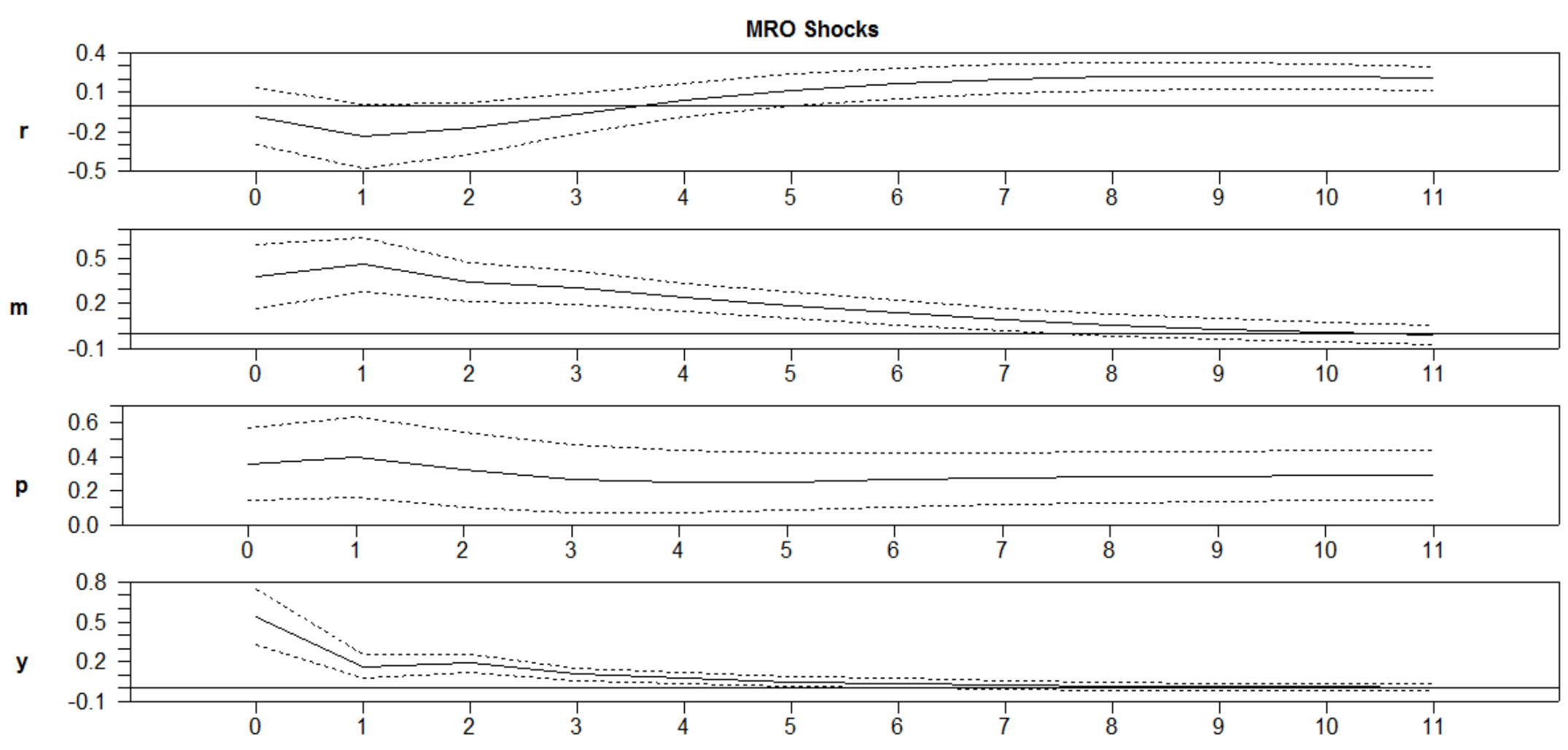


Figure 3.9 Impulse Responses of Inflation Rate
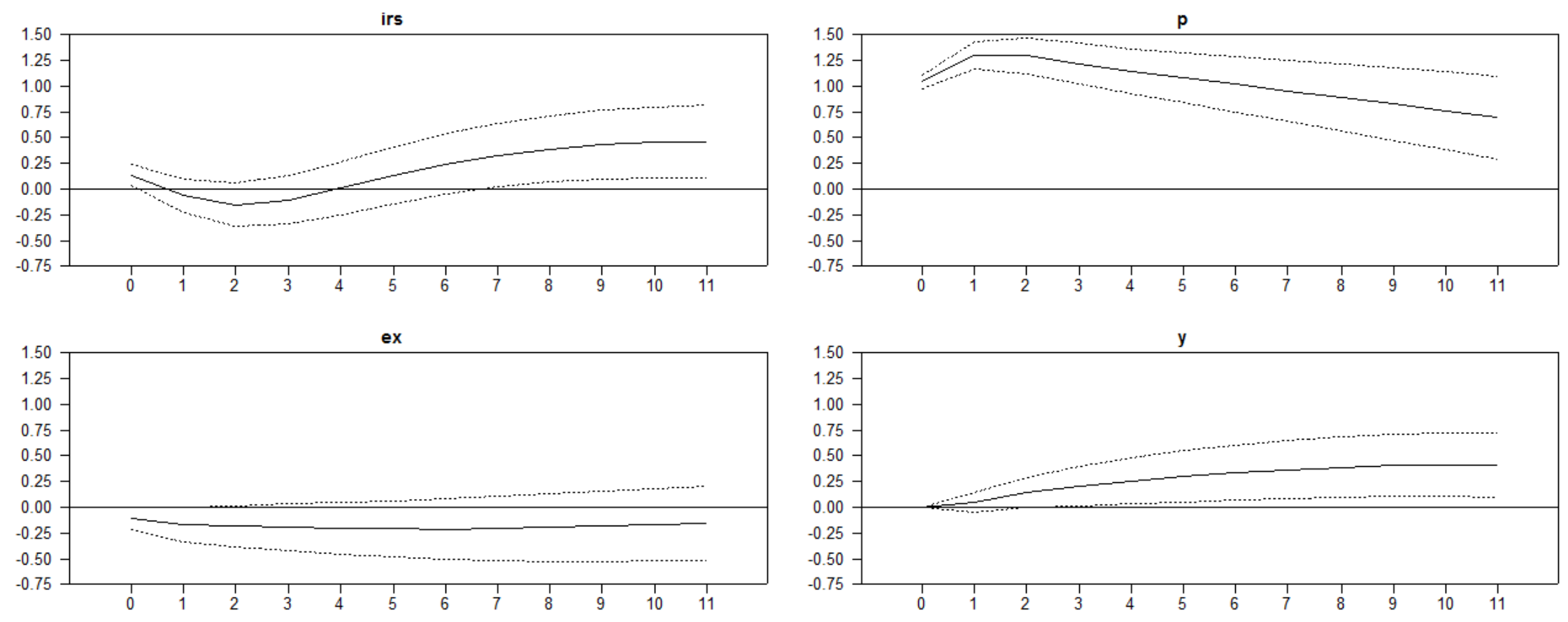

\section{Responses of $p$}


Figure 3.10 Impulse Responses of Exchange Rate
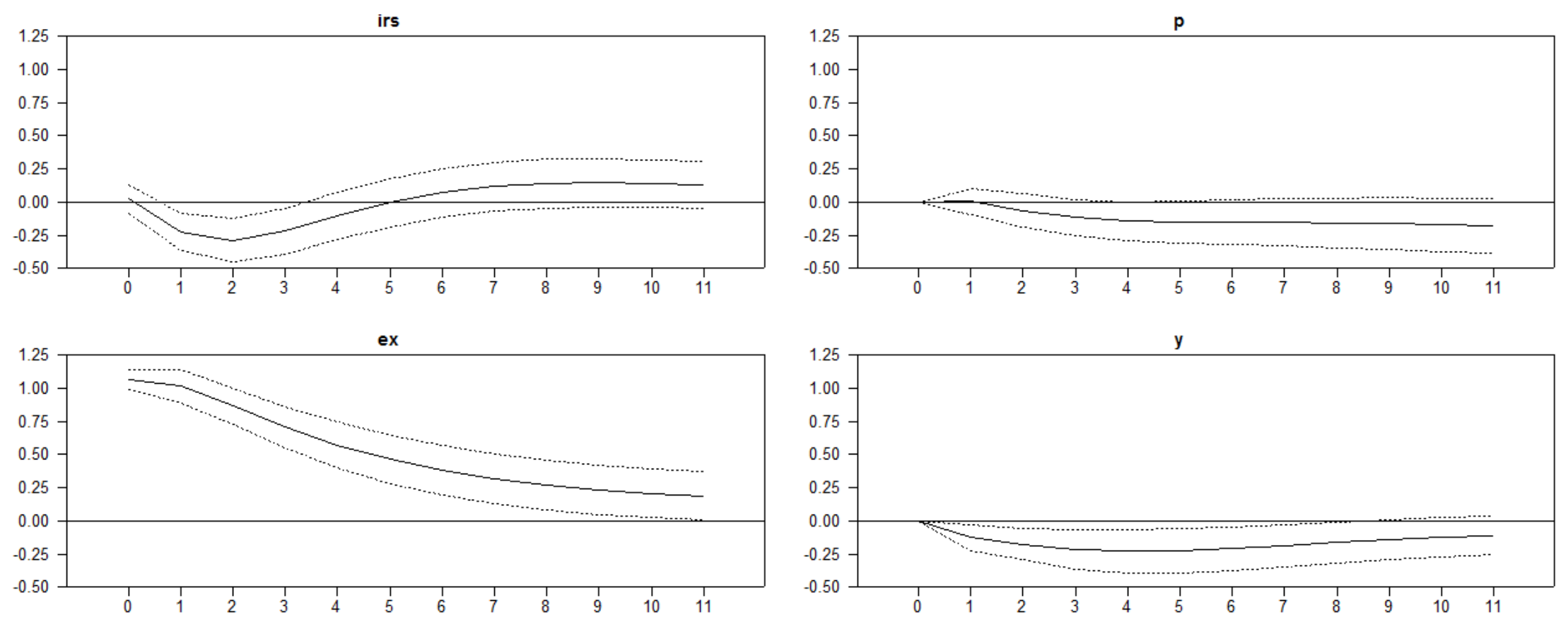

Responses of ex 
Figure 3.11 Impulse Responses of Output
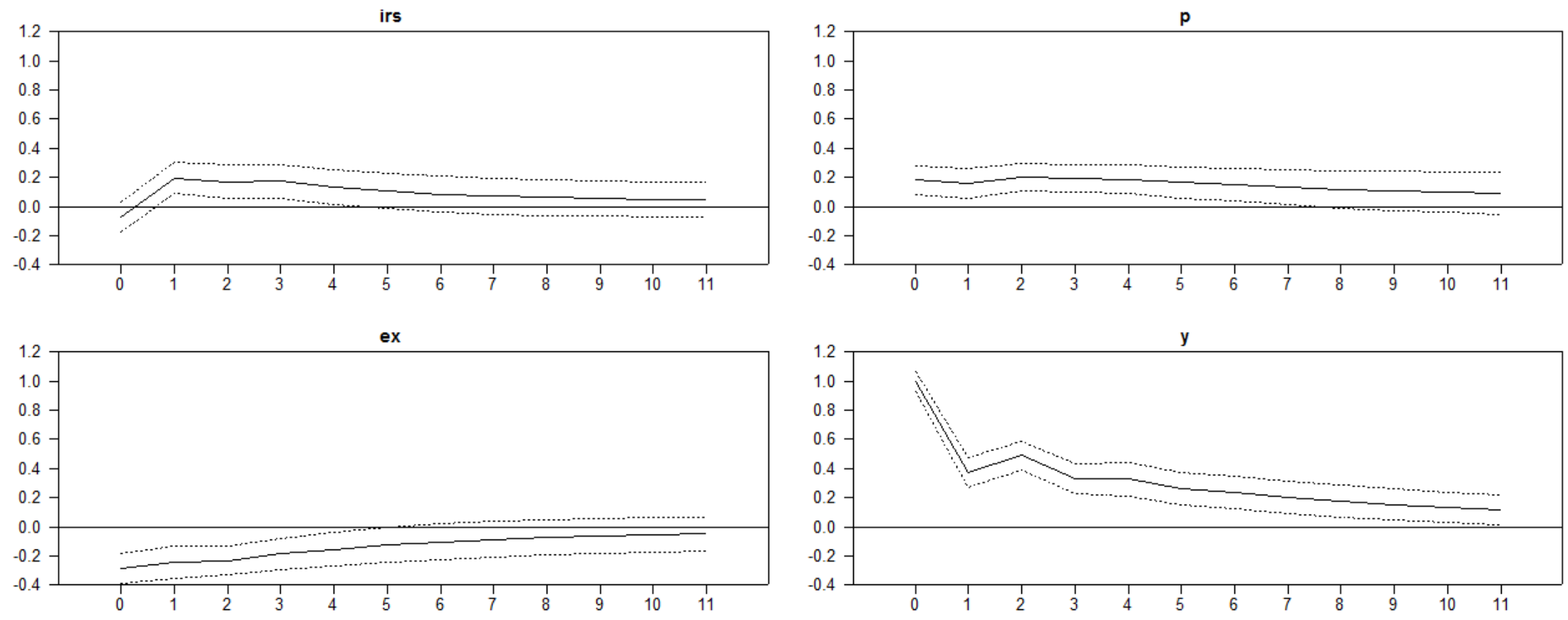

Responses of y 
Figure 3.12 Impulse Responses of the Interest Rate Spread
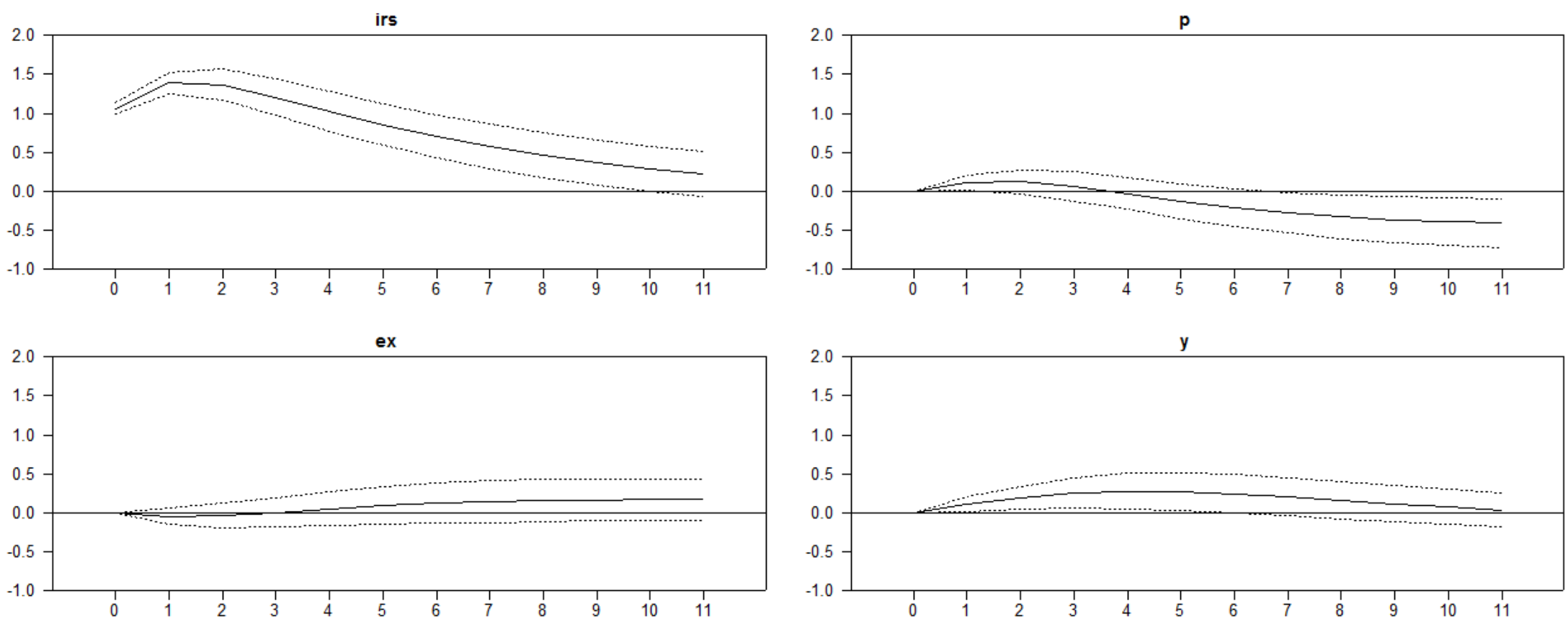

\section{Responses of irs}


Figure 3.13 Impulse Responses of Growth Rate in Domestic Money Supply
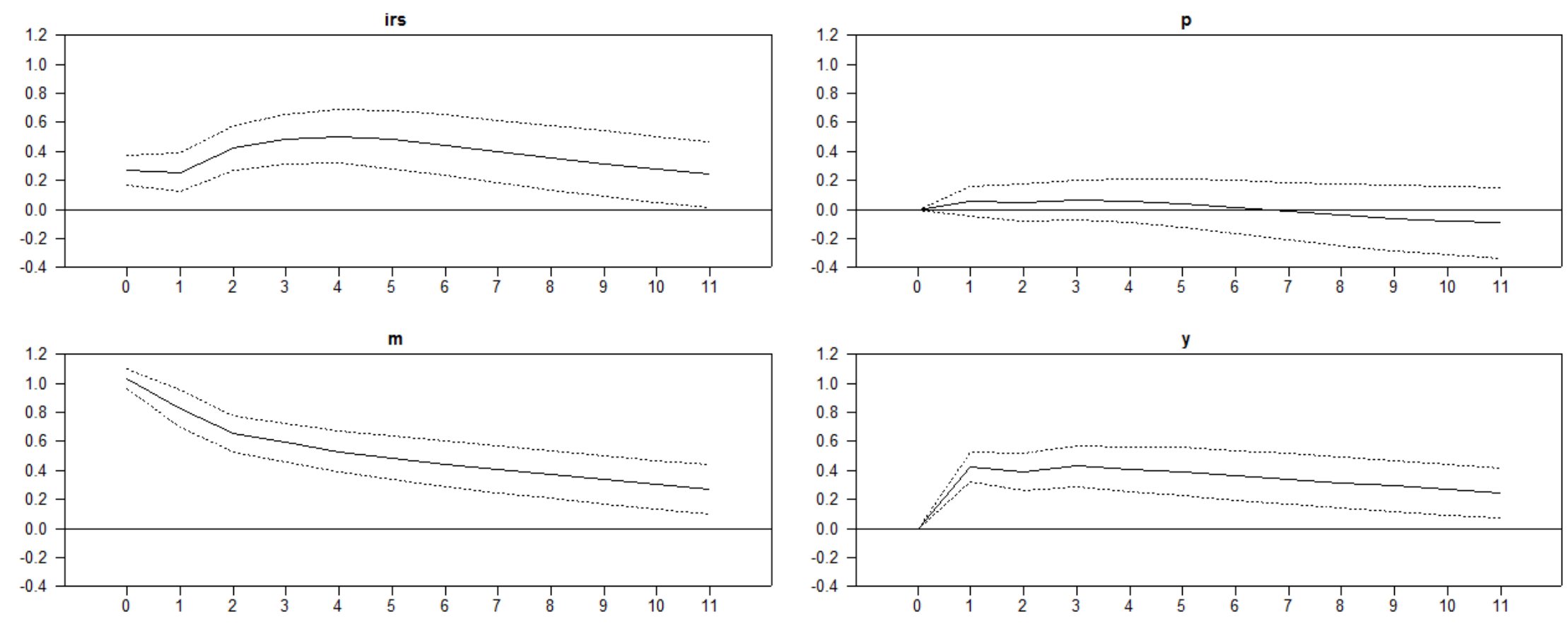

Responses of $\mathrm{m}$ 
Figure 3.14 Impulse Responses of the Interest Rate Spread
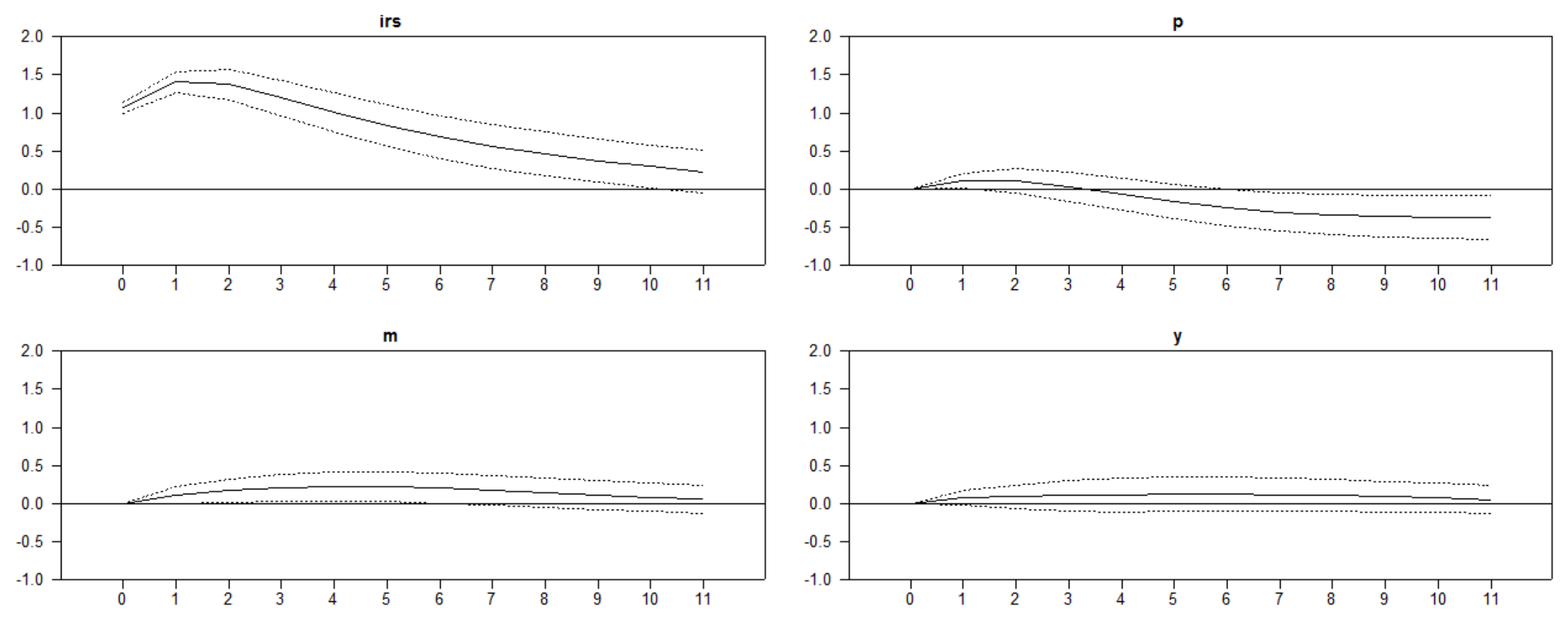

\section{Responses of irs}


Figure 3.15 Impulse Responses of Inflation Rate
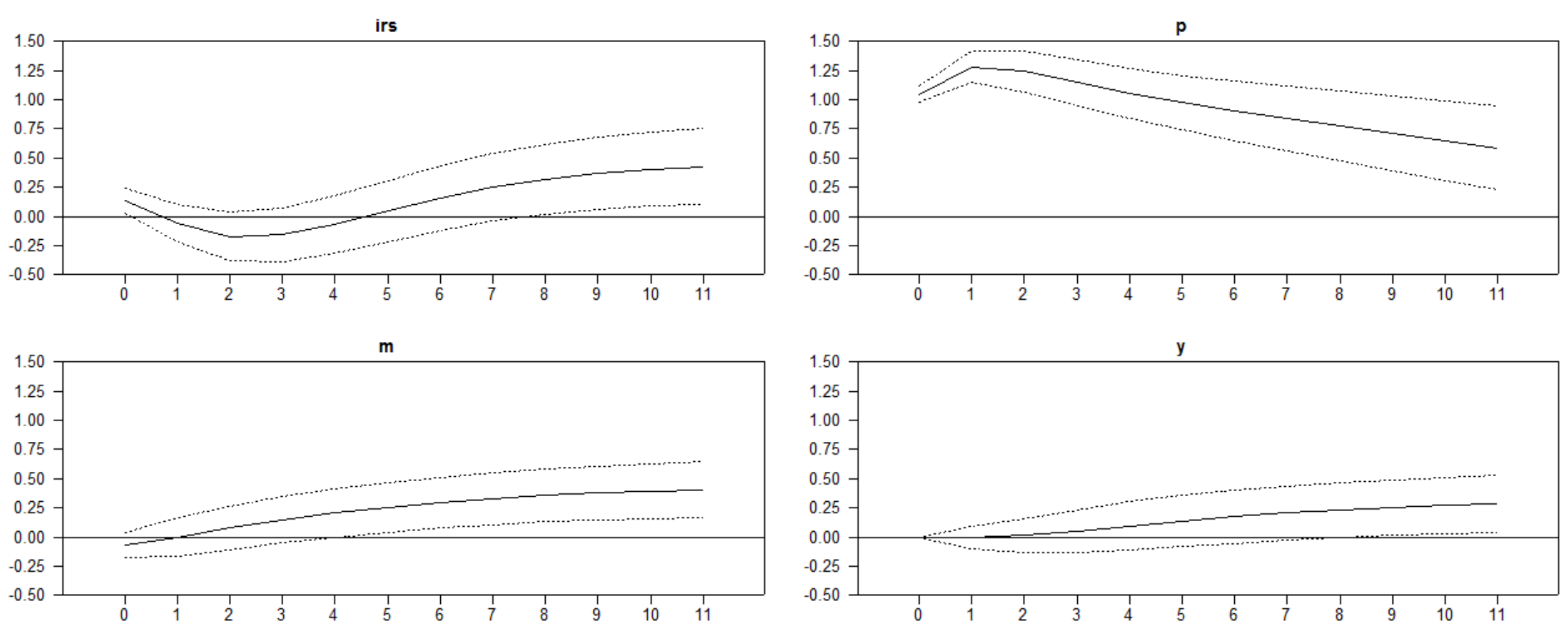

Responses of $p$ 
Figure 3.16 Impulse Responses of Output
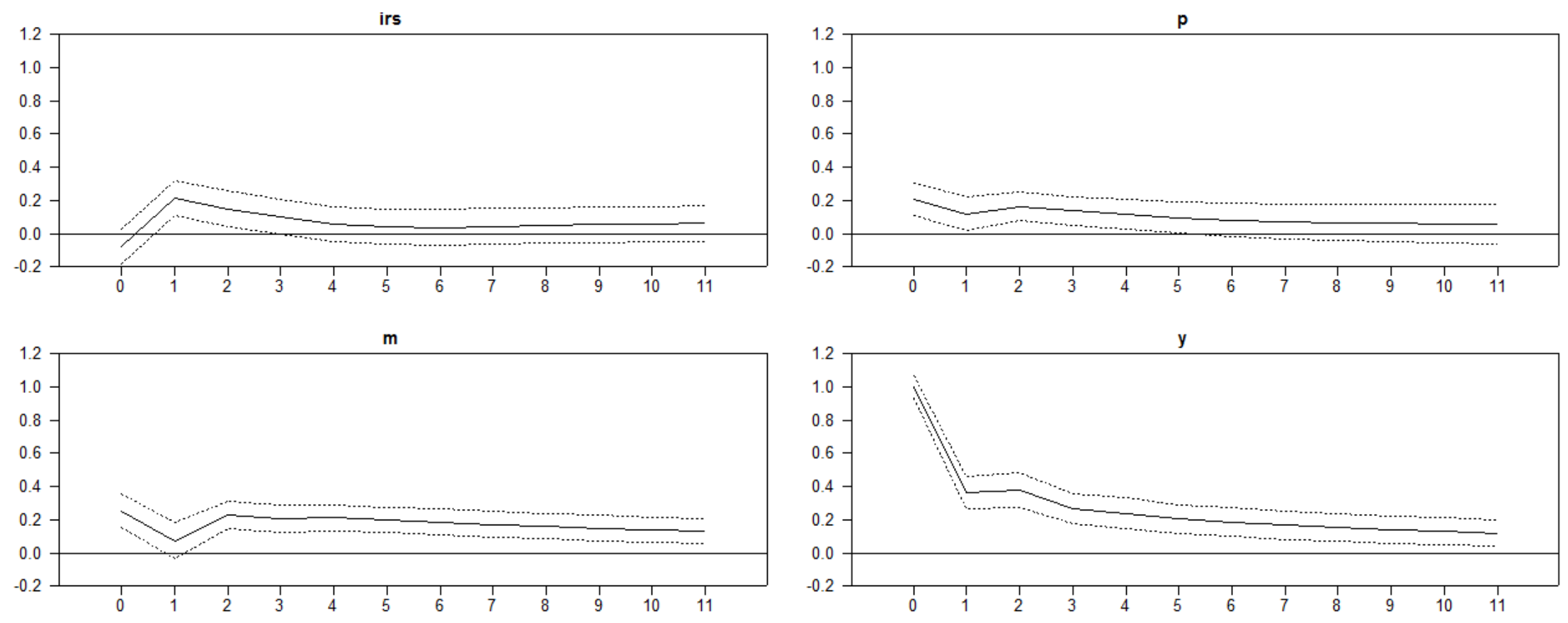

\section{Responses of $y$}




\section{Bibliography}

Atkinson, Anthony B., Thomas Piketty, and Emmanuel Saez. "Top Incomes in the Long Run of History." Journal of Economic Literature, 49 (2011): 3-71.

Bhattacharya, J., J. H. Haslag and A. Martin. "Heterogeneity, Redistribution, and the Friedman Rule." International Economic Review, 46(2005): 437-454.

Bordo, M. D. and C.M. Meissner. "Does inequality lead to a financial crisis?" Journal of International Money and Finance, 31(2012): 2147-2161.

Coibion, Olivier, et al. "Innocent Bystanders? Monetary Policy and Inequality in the U.S." NBER, working paper \#18170. 2012.

Conceicao, Pedro and Pedro Ferreira. “The Young Person's Guide to the Theil Index: Suggesting Intuitive Interpretations and Exploring Analytical Applications." University of Texas Inequality Project, working paper. 2000.

Debelle, Guy. "Household Debt and the Macroeconomy." BIS Quarterly Review, 2004: 51-64.

Diebold, Francis and Kamil Yilmaz. "Better to Give Than to Receive: Predictive Directional Measurement of Volatility Spillovers." International Journal of Forecasting, 28(2012): 57-66.

Dynan, Karen E. and Donald L. Kohn. "The Rise in U.S. Household Indebtedness: Causes and Consequences." Federal Reserve Board Finance and Economics Discussion Series, working paper \#2007-37. 2007.

Forno, Mario and Luca Gambetti. "Sufficient Information in Structural VARs." Journal of Monetary Economics, 66(2014): 124-136.

Iacoviello, Matteo. "Household Debt and Income Inequality, 1963-2003." Journal of Money, Credit, and Banking, 40(2008): 929-965.

Ireland, P. N. "Heterogeneity and Redistribution: By Monetary or Fiscal Means." International Economic Review, 46(2005): 455-463.

Ireland, Peter. "The Monetary Transmission Mechanism." Federal Reserve Bank of Boston, working paper. 2006.

Koop, Gary, M. Hashem Pesaran, and Simon Potter. "Impulse Response Analysis in Nonlinear Multivariate Models.” Journal of Econometrics, 74(1996): 119-147.

Kumhof, Michael, and Romain Ranciere. "Inequality, Leverage, and Crises." International Monetary Fund, working paper. 2013.

Levy, Frank and Peter Temin. "Inequality and Institutions in $20^{\text {th }}$ Century America." NBER, working paper \#13106. 2007.

Piketty, Thomas. Capital in the Twenty-First Century. Cambridge, MA: Belknap Press, 2014. Print.

Philippon, Thomas. "Has the U.S. Finance Industry Become Less Efficient? On the Theory and Measurement of Financial Intermediation." American Economic Review, forthcoming. 2014. 
Rajan, R. G. Fault Lines: How Hidden Fractures Still Threaten the World Economy. Princeton University Press, 2010. Print.

Reich, R. B. Aftershock: The Next Economy and America's Future. New York: Random House. 2010. Print.

Stiglitz, Joseph. The Great Divide: Unequal Societies and What We Can do About Them. New York: W.W. Norton \& Company, 2015a. Print.

Stiglitz, Joseph. “The Measurement of Wealth: Recessions, Sustainability, and Inequality.” NBER, working paper \#21327. 2015 b.

Stiglitz, Joseph. The Price of Inequality: How Today's Divided Society Endangers our Future. New York: W.W. Norton \& Company, 2012. Print.

Wolff, Edward N. "Household Wealth Trends in the United States, 1962-2013: What Happened Over the Great Recession?” NBER, working paper \#20733. 2014.

Aaberge, Rolf, et al. "Unemployment shocks and income distribution: how did the Nordic countries fare during their crises?" The Scandinavian Journal of Economics 102.1 (2000): 77-99.

Atkinson, Anthony B., Thomas Piketty, and Emmanuel Saez. "Top incomes in the long run of history." Journal of economic literature 49.1 (2011): 3-71.

Barro, Robert J. "Inequality and Growth in a Panel of Countries." Journal of Economic Growth 5.1 (2000): 5-32.

Bonser-Neal, Catherine, and Timothy R. Morley. "Does the yield spread predict real economic activity? A multicountry analysis." Economic Review-Federal Reserve Bank of Kansas City 82.3 (1997): 37.

Clark, Todd E., and Michael W. McCracken. "Tests of equal forecast accuracy and encompassing for nested models." Journal of Econometrics 105.1 (2001): 85-110. 74100-6

Dew-Becker, Ian, and Robert J. Gordon. "Where did the productivity growth go? Inflation dynamics and the distribution of income". No. w11842. National Bureau of Economic Research, 2005.

Diebold, Francis and Kamil Yilmaz. "Better to Give Than to Receive: Predictive Directional Measurement of Volatility Spillovers.” International Journal of Forecasting 28(2012): 57-66.

Easterly, William, and Stanley Fischer. "Inflation and the Poor." Journal of Money, Credit and Banking (2001): 160-178.

Estrella, Arturo, and Gikas A. Hardouvelis. "The term structure as a predictor of real economic activity." The Journal of Finance 46.2 (1991): 555-576. 
Estrella, Arturo, Anthony P. Rodrigues, and Sebastian Schich. "How stable is the predictive power of the yield curve? Evidence from Germany and the United States." Review of Economics and Statistics 85.3 (2003): 629-644.

Fama, Eugene F., and Kenneth R. French. "Business conditions and expected returns on stocks and bonds." Journal of Financial Economics 25.1 (1989): 23-49.

Forbes, Kristin J. "A reassessment of the relationship between inequality and growth." American economic review (2000): 869-887.

Frank, Mark W. "Inequality and growth in the United States: Evidence from a new state-level panel of income inequality measures." Economic Inquiry 47.1 (2009): 55-68.

Frank, Mark, Estelle Sommeiller, and Mark Price. "Update on Other Measures of Income Inequality (Atkinson Index, Gini Coefficient, Relative Mean Deviation, Theil Index), 1917-2013”. http://www.shsu.edu/eco_mwf/inequality.html

Koop, Gary, M. Hashem Pesaran, and Simon M. Potter. "Impulse response analysis in nonlinear multivariate models." Journal of econometrics 74.1 (1996): 119-147.

Mo, Pak Hung. "Income inequality and economic growth." Kyklos 53.3 (2000): 293-315.

Ozturk, Huseyin, and Luis Felipe VN Pereira. "Yield Curve as a Predictor of Recessions: Evidence from Panel Data." Emerging Markets Finance and Trade 49.sup5 (2013): 194-212.

Parker, Jonathan A., and Annette Vissing-Jorgensen. Who bears aggregate fluctuations and how? No. w14665. National Bureau of Economic Research, 2009.

Partridge, Mark D. "Does Income Distribution Affect US State Economic Growth?" Journal of Regional Science 45.2 (2005): 363-394.

Persson, Torsten, and Guido Tabellini. Is inequality harmful for growth? Theory and evidence. No. w3599. National Bureau of Economic Research, 1991.

Piketty, Thomas, and Emmanuel Saez. Income Inequality in the United States, 1913-1998 (series updated to 2000 available). No. w8467. National bureau of economic research, 2001.

Piketty, Thomas. "Capital in the 21st Century." Cambridge: Harvard Uni (2014).

Romer, Christina D., and David H. Romer. Monetary policy and the well-being of the poor. No. w6793. National Bureau of Economic Research, 1998.

Wheelock, David C., and Mark E. Wohar. "Can the term spread predict output growth and recessions? A survey of the literature." Review 91 (2009).

Anzuini, A., \& Levy, A. (2007). Monetary policy shocks in the new EU members: A VAR approach. Applied Economics, 39(9), 1147-1161. 
Benkovskis, K., Bessonovs, A., Feldkircher, M., \& Wörz, J. (2011). The transmission of Euro Area monetary shocks to the Czech Republic, Poland and Hungary: evidence from a FAVAR model. Focus on European Economic Integration, 3, 8-36.

Botrić, V., \& Cota, B. (2006). Sources of Inflation in Transition Economy: The Case of Croatia. Ekonomski pregled, 57(12), 835-854.

Bokan, N., Grguric, L., Krznar, I., \& Lang, M. (2009). The impact of the financial crisis and policy responses in Croatia. Working Paper W-22, Zagreb: Croatian National Bank.

Canova, F. (2005). The transmission of US shocks to Latin America. Journal of Applied econometrics, 20(2), 229-251.

Fahr, S., Motto, R., Rostagno, M., Smets, F., \& Tristani, O. (2013). A monetary policy strategy in good and bad times: Lessons from the recent past. Economic Policy, 28(74), 243-288.

Giannone, D., Lenza, M., Pill, H., \& Reichlin, L. (2012). The ECB and the Interbank Market*. The Economic Journal, 122(564), F467-F486.

Malešević-Perović, Lena. "Cointegration approach to analysing inflation in Croatia." Financial theory and practice 33.2 (2009): 201-218.

Petrevski, Goran, Jane Bogoev, and Dragan Tevdovski. "The transmission of foreign shocks to South Eastern European economies." Empirica (2013): 1-21.

Tkalec, M. (2012). The Dynamics of Deposit Euroization in European Post-transition Countries: Evidence from Threshold VAR*. Finance a Uver, 62(3), 278.

Sousa, J., \& Zaghini, A. (2008). Monetary policy shocks in the Euro Area and global liquidity spillovers. International journal of finance \& Economics, 13(3), 205-218.

Vizek, M., \& Broz, T. (2009). Modeling inflation in Croatia. Emerging markets finance and trade, 45(6), 87-98. 